\title{
Wokół medalu
}

\section{biskupa Andrzeja Trzebickiego}

KRZYSZTOF J. CZYŻEWSKI

ZAMEK KRÓLEWSKI NA WAWELU - PAŃSTWOWE

ZBIORY SZTUKI

MAREK WALCZAK

INSTYTUT HISTORII SZTUKI UJ

ORCID: 0000-0003-4649-8521

Jedną z prerogatyw władców było bicie

własnej monety, która poza pełnieniem

oczywistych funkcji ekonomicznych stano-

wiła istotny nośnik treści propagandowych

i narzędzie autokreacjii. Emitentami numi-

zmatów byli nie tylko przedstawiciele elity

świeckiej, ale i duchownej, na czele z papie-

zem. Wielu spośród arcybiskupów i bisku-

pów, będących zarazem książętami ziem-

skimi, utrzymywało własne mennice.

W okresie nowożytnym biły one także medale. Nie tylko kruszcowy materiał (złoto, srebro, miedź i jego stopy czasami ołów),

i kolisty (ewentualnie owalny) ksztatt ikusty (ewentualnie owalny) ksztattoraz Medale określano czasem niemieckim

1 Z opracowań o charakterze całościowym warto wskazá́: R. Kiersnowski,
średnich, Warszawa 1988.

2 Na temat kategoryzacji badań and medalami zob. grafia oraz medalistyka i medalierstwo a nauki pomocnicze historii, w: Polskie medalierstwo kościelne - tradycja i wspótczesność. Konferencja naukowa 17 grudnia 2007 r., red. P. Dudziński, K. Łatak, Kraków mianem Schaumünzen lub łacińskim numibyła wieloraka, z naciskiem na komemorację i autokreację. Podobnie jak medale kolejnych lat pontyfikatu biskupów Rzymu, upamiętniały one ważne wydarzenia w życiu hierarchów oraz ich lokalnych Kościołów ${ }^{4}$. Jako prestiżowe podarunki stanowiły sposób na pozyskanie łaski u władców, stanowiły także formę nagradzania stronników i wyróżniania ważnych gości, a także osób bliskich ${ }^{5}$. Ich ranga mimo niewielkich rozmiarów, była bardzo wysoka, co skutkowa rozwojem kolekcjonerstwa powstaniem licznych gabinetów, w któ-

J. Štěpán, Nejstarší medailérské ražby olomouckého biskupství, w: Stanislav Pavlovskýz Pavlovic (1579-1598. Biskup a mecenás umírajijciho věku, red. O. Jakubec,

Olomouc 2009, s. 133 .
Literatura na temat medali papieskich jest bardzo obszena, Mozna tu wskazac podstawową w tym rum Pontificum, wydawana od r. 2002, a także takie opracowania, jak: F. Buonanni, Numismata summorum pontificum templi Vaticani fabricam indicantia, chronologica ejusdem fabricae narratione, ac multiplici erudition explicata, Romae 1700; Serie dei conj di medaglie . Roma 1824; J. Stachowiak, Dziatalność papieska medalami pisana, w: Polskie medalierstwo.., dz. cyt., s. 25-55.

5 W przypadku biskupów ołomunieckich źródłowo potwierdzone są także przypadki nagradzania medalam portretowymi agentów artystycznych. J. Zapletalova
(Art) Agents: Giovanni Petignier and the Network of Agents of the Olomouc Bishop Korl von LichtenstenCastelcorno, „Uměni”', t. 65, 2017, s. 350, il. 2. rych gromadzono na równi monety, jak medale. Ich opisy, czesto z szerokim komentarzem, wydawano drukiem.

Geograficznie bliskim Krakowa przykładem działalności na polu mennictwa jest biskupstwo ołomunieckie. Pierwsze medale złotnik Donath Scholcz wykonał w 1585 r. dla biskupa Stanisława Pawłowskiego (1579-1598)6. Jego następca, kard. Franciszek Dietrichstein (1570-1636), otrzymał w 1608 od cesarza Rudolfa II przywilej menniczy dla biskupów ołomunieckich, realizowany w mennicy ulokowanej w Kromieryżu?. Jeśli chodzi o episkopat państwa polsko-litewskiego, to nie licząc biskupów wrocławskich, podlegających metropolicie gnieźnieńskiemu, ale politycznie przynależnych do Rzeszy 8 , aktywność na tym polu zostado Rzeszy
wiła a ałabe ślady9 . Pomijamy tutaj kuriozalny

6J. Štěpán, Zlatník Donát šolc, medailér olomouckého biskupa Stanislava Pavlovskeho z Pavlovic, „Numismatické listy" 2001, nr 56, s.115-118; tenże, Nejstarš J.Štěpán O. Jakubec) s. 136-137, poz. 40-41 (oprac. J. Štěpán).

J. Videman, Kardinál Františék z Dietrichsteina a jeho mincovnictví, w: Kardinál František z Dietrichsteina (1570-1636). Prelát a politik neklidného vèku,

8 Biskupstwo wroctawskie w numizmatyce isfragistyce. wiul V-XI 1997, wyd B. Marcisz, M. Ke me we Wrocta1997; M. Karnicka, Monety dukatowe i talarowe oraz medale biskupów wroctawskich powstate w okresie od XVI do XVIII wieku w zbiorach Muzeum Narodowego we Wroctawiu, w: Nysa. Sztuka w dawnej stolicy ksiesstwa biskupiego, red. R. Hołownia, M. Kapustka,
Nysa 2008, s. 223-231. 9 Monety biskupów polskich, w: Z. Gloger, Encyklopedja a, t. 3, Warszawa 1902, Poznań 1921; M. Gumowski, Prawo mennicze biskupów polskich w wiekach średnich, „Ateneum Kapłańskie 1926, nr 17-18, s.1-19, S. Suchodolski, Moneta możnoWroctaw 1987: M. Pauk, Moneta episcopalis: mennictwo biskupie w Europie Środkowei X-XIII w. ijego zachodnioeuropejski kontekst, Przeglad Historyczny" t. 101, 2010, z. 4, s. 539-571. W okresie nowożytnym charakter unikatu ma dukat abpa gnieznienskiego przypadek monet emitowanych rzekomo przez krakowskiego biskupa Kajetana Sołtyka jako księcia siewierskiego'

Wiadomo, że owe numizmaty powstały już po śmierci biskupa, ok. 1800 r., na zlecenie jego synowca Michała ${ }^{11}$. Spośród nowożytnych biskupów krakowskich medalami uhonorowani zostali, o ile wiadomo, tylk czterej $^{12}$ : Piotr Myszkowski 1565 r. $^{13}$ i niedatowany ${ }^{14}$ ), Franciszek Krasiński

$r 23,24$ lutego 2001 r., Warszawa 2001, s. 29, poz. 347

K.W. Stężyński Bandtkie, Numismatyka krajowa, t. 2 Warszawa 1839, s. 55, tabl. 48, nr 580-581; E. HuttenMapsil, Catalogue de la Collection des Médailles et s.69-70, poz 3009 (trebro, stopinbourg 1872 , i miast do ie niegdy nalez Polsh jako tez prowincy wieków, wyd. E. Rastawiecki, Warszawa 1845, s. 91-92 poz. 691-692: D. Marciniak, Grosz siewierski biskupa Kajetana sottyka, https://gndm.pl/grosz-siewier

12 I. Polkowski, Medale biskupów polskich, w: Encyklopedja kościelna podług teologicznej encyklopedji Wetzera Welego, wyd. M. Nowodworsh, t. I4, Warszawa

, súski, Gabinet medalów polskich oraz tych które się dziejów Polski tyczą poczzawszy od najdawniejszych aż collection de médailles ayant rapport a l'histoire de ce pays depuis les plus anciennes jusq'a celles, qui ontété frappes souslerégne du roi Jean III. (1513-1696), t. 2, Berlin 1845, s. 422-423, poz. $92 \mathrm{~b}$; E. Hutten-Czapski, dz. cyt., w Krakowie, Kraków 1908, s. 38, poz. 415-416.

14 A. Ledóchowski, Notice sur deux médailles Polonaises inedites, qui se trouvent dans le Cabinet Royal de Munich en Bavierere, ,Koehne's Zeitschrift für Münz-, Siegel- und Wappenkunde" 1842 , nr 2, s. 327, 329, il. 2, Berlin 1845, s. 382-383, nr 92a (egzemplarz w M.,. 1, chium); E. Hutten-Czapski, dz. cyt, t. 2. s. 504, poz. 5399 (brąz, stopień rzadkości R'); A. Więcek, Dzieje sztuki medalierskiej w Polsce, wyd. II poszerzone i uzupetnione, Krakow 1989, s. 41, il. 46; P. Kalinowski, poz. 2. Tradycyine datowany nar. 1578 , we nowszych ustaleń datowany po r. 1577 , może r. 1591 jako upamiętnienie śmierci. Medale polskie iz Polska zwiazane z okresu Pierwszej Rzeczypospolite. Katalog zbiorów. Zamek Królewski w Warszawie - 
(1574) ${ }^{15}$, Andrzej Trzebicki $(1677)^{16}$ i Andrzej Stanisław Kostka Załuski (1759) ${ }^{17}$. Piękny bardzo rzadki medal poświęcony

Andrzejowi Trzebickiemu stanowi temat niniejszego tekstu, chociaż pozostałe także zasługują na większą uwagę badaczy. Podstawę opracowania stanow egzemplarz znajdujący się w zbiorach Muzeum Narodowego w Krakowie (MNK VII-MdP-1094), który przedstawia się następująco: bity w złocie, okrągły, średnicy 42,1 mm, waga $34,75 \mathrm{~g}$, czyli w przybliżeniu 10 dukatów $w^{18}$ (il. 1). Na awersie przedstawiono popiersie biskupa w prawo (głowa z proflu, pierślekkozwrócona ku widzowi). Sportretowany zostat w piusce, w mo. Sportretowany zostal w piusce, w moce z niewielkim kapturkiem, zapinanym z przodu na szereg drobnych guziczków, z których kilka rozpiętych (zapewne do wysunięcia łańcucha z krzyżem

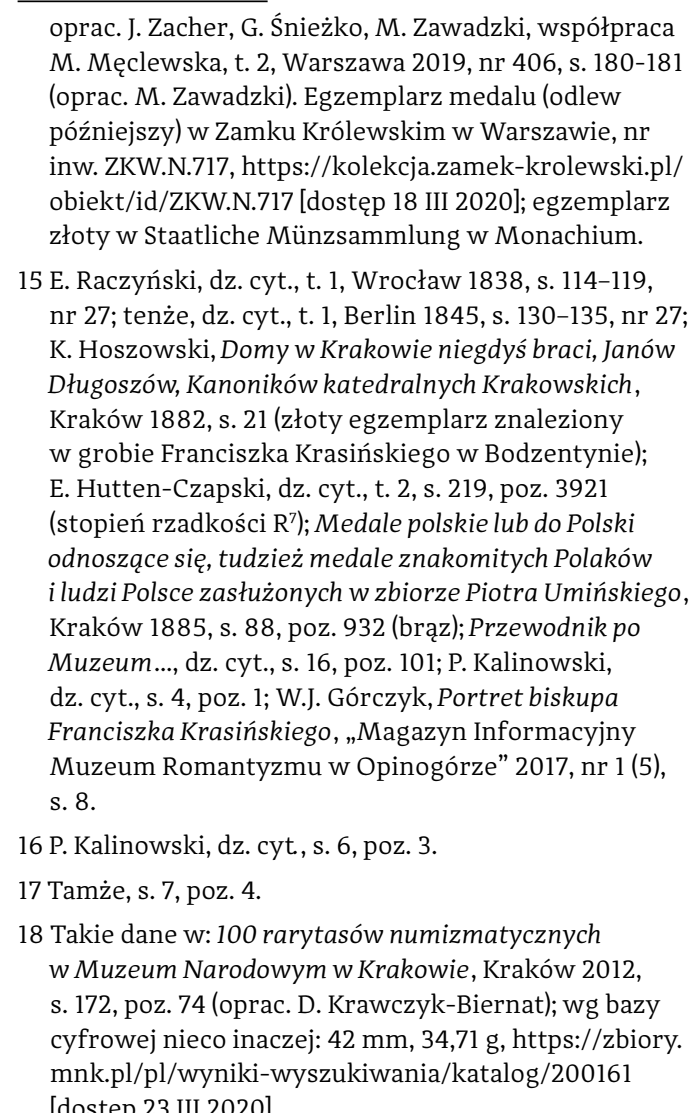

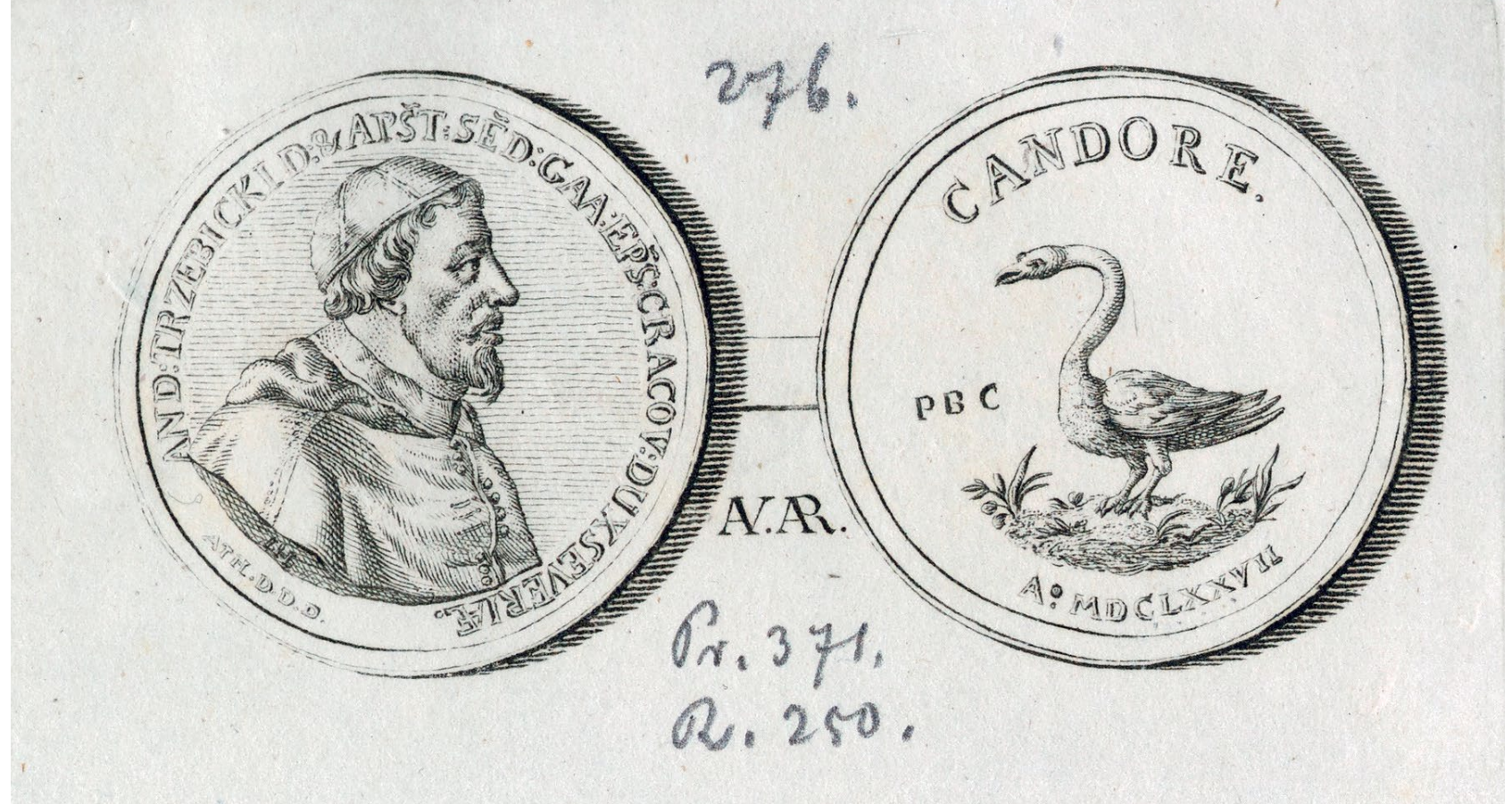

2. Medal Andrzeja Trzebickiego z $1677 \mathrm{r}$., akwaforta, Ryciny Medali Polskich do dzileta X.B. Albertrandego. „Historya Polska Medalantizaswiadczona" przygotowane przez Księcia Henryka Lubomirskiego 1822-1830 r. Utozone porzadkiem według „Spis poz. 207. Fot. MNK

pektoralnym), przy szyi kołnierz wyłożony na mocet. Dookoła biegnie legenda zawierajacca imię, nazwisko i tytulature:

AND(REAS): TRZEBICKI D(EI): (ET) AP(O)

ST(OLICAE): SED(IS): GRA(TI)A: EP(IS)C(OPU) S CRACOV(IENSIS): DUX SEVERIAE". Poniże popiersia sygle: „ATH ${ }^{19}$ D.D.D.”, a na przecię ciu ramienia biskupa sygnatura wykonawcy: IH. Na rewersie został ukazany profilowo, skierowany w lewo łabędź, stojący na skrawku gruntu porośniętego trawą

19 Odstepp miedzy litera Ti i wydaje sie nieco wiekszy, niż między literami AT, co może mieć znaczenie dla odczytu. Trudno jednakże jednoznacznie przesądzić, czy ta niewielka różnica ma charakter intencjonalny
czy przypadkowy. i niskimi szuwarami (?). Powyżej biegnie łukowato inskrypcja: „CANDORE.”, poniżej zapisana mniejszymi literami data roczna: "A(NN) $)^{\circ}$ MDCLXXVII". Krawędzie medalu po obu stronach zaakcentowano profilowaną listewką. Przedstawienie biskupa wykonane zostało bardzo starannie, z uwzględnieniem drobnych detali, jak szwy na piusce i mocecie. Także i w przypadku łabędzia zwraca uwagę precyzyjne oddanie upierzenia. Wyobrażenia potraktowano bardzo plastycznie, oddając je w wysokim reliefie.

Z publikacji dowiadujemy się o istnieniu innych, poza krakowskim, złotych egzemplarzy. Jeden znajdował się w Gabinecie 
Numizmatycznym Uniwersytetu

Warszawskiego $0^{20}$. Jego wygląd dokumentuje akwaforta zachowana m.in. w Muzeum Narodowym w Krakowie, w albumie kolekcjonerskim pod tytułem: Ryciny Medall Polskich do dzieła X.B. Albertrandego: "Historya Polska Medalami zaświadczona" przygotowane przez Księcia Henryka ubomirskiego 1822-1830 $r$. Ułożone porzadkiem według „Spisu Medali Polskich” Feliksa Bentkowskiego 1832 r., oznaczona numerem $207^{21}$ (il. 2). Miała ilustrować publikację na temat polskich numizmatów, przyootowaną do druku przez Królewskie Towarzystwo Przyjaciół Nauk w Warszawie, lecz niezrealizowaną z powodu rekwizycji płyt graficznych w ramach represji po powstaniu listopadowym ${ }^{22}$. Na rewersie zadokumentowanego egzemplarza widać po lewej

20 F. Bentkowski, Spis medalów polskich lub z dziejami krainy polskiej stycznych, w Gabinecie Król. Alekx. Uniwersytetu w Warszawie znajdujacych się, tudz i porzadkiem lat ułożony, Warszawa 1830, s. 81 poz. 276; K. Hoszowski, Żywot Andrzeja Trzebickiego biskupa krakowskiego księcia siewierskiego, Kraków 1861, s. 315, przyp. 63.

21 Nr inw. MNK IIII-ryc.-32243, akwaforta, wyd. Andreas Geiger w Wiedniu, https://zbiory.mnk.pl/pl/wyniki-wyszuliwania/katalog/240 [dostep 24 iti 2020]. Dit Towarzystwo Przyliaciót] Nauk Medale Polskie, nr inw MNK III-ryc.-53211/424, https://zbiory.mnkk.pl/pl// wyniki-wyszukiwania//katalog/417967 dostęp 24 II 2020].

22 K. Podniesińska, Trzy komplety „Rycin medali polskich odbitych z blach Krolewskiego Towarzystwa Przyjaci Nauk $w$ Warszawie przechowywane $w$ zbiorach Wiadomości Numizmatyczne", r. 60, 2016, . . 1-2, s. 63-88; taż, Pięć albumów z rycinami medali polskich do dzieła "Historia polska medalami zaświadczona i objaśniona "biskupa Jana Chrzciciela Albertrandego, „Res Gestae. Czasopismo Historyczze" 2016, nr 3, "mien słośnego niegdyś po świecie narodu"-jeszce

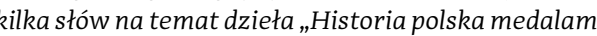
zaświadczona iobjaśniona" Jana Chrzciciela Albertran-

diego , ,Wiadomości Numizmatyczne" r. 62, 2018 stronie łabędzia litery PBC, być może oznaczenie kolekcjonerskie ${ }^{23}$. Kolejny medal bity w złocie znajdował się kiedyś w zbiorze Józefa Zeltta Mł. w Warszawie ${ }^{24}$, o czym wspomina Konstanty Hoszowski ${ }^{25}$. Dnia 14 stycznia 2014 r. pojawił się na 3029. aukcj Heritage Auctions w Nowym Jorku (Eric P. Newman Collection Part III Signature Auction) medal w wersji złotej, średnicy $41 \mathrm{~mm}$, wagi $34,752 \mathrm{~g}$ (poz. 30233), pochodzący z kolekcji Erica P. Newmana ${ }^{26}$ (il. 3). Jego pojawienie się na rynku było wielkim wydarzeniem, opisano go jako „Possibly Unique Baroque Masterpiece”. Oznaczony został przy tej okazji przez Numismatic Guaranty Corporation jako AU $58^{27}$. Jego wartość szacunkową określono na poziomie 30.000-40.00o dolarów, a cena wylicytowana osiągnęła 58.750 dolarów ${ }^{28}$. Medal

23 Natura graficznego przekazu nie pozwala na stwierdzenie, jaką techniką wykonano na oryginalnym numizmacie to oznaczenie (rytowane?

malowane?)

24 Józef Zeltt (1841-1911), kolekcjoner monet i medali, autor Nowego skorowidza monet polskich (Warszaw

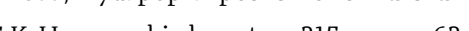
25 K. Hoszowski, dz. cyt., s. 315, przyp. 63. 26 Eric Pfeiffer Newman (1911-2017), amerykański numizmatyki kolekcjoner, swoje zbiory sprzedał które preznaczył na uf Numismatic Education Society oraz Newman Numismatic Portal, L. Ausberger, R.W. Burdette, J. Orosz, Truth Seeker: The Life of Eric P. Newman,

27 NGC Newsletter: November 2013, s. nlb. Symbol AU oznacza, że medal posiada niewielkie ślady zużycia coin-grading/details-grading/[dostep $1 \mathrm{~V}$ 2020] dodatkowa numeryczna skala pokazuje stan numizmatu, numery od 50 do 58 oznaczaja, że prawie nie był on w obiegu (,About Uncirculated"), https:// www.ngccoin.com/coin-grading/grading-scale/

28 Heritage World Coin Auction January 14-16, 2014, New Part III, New York 2014, s. 177, poz. 30233, fotografia medalu umieszczona wśród najważniejszych cymeliów na okładce. https://coinweek.com/ auctions-news/eric-p-newman-collection-part-iil-
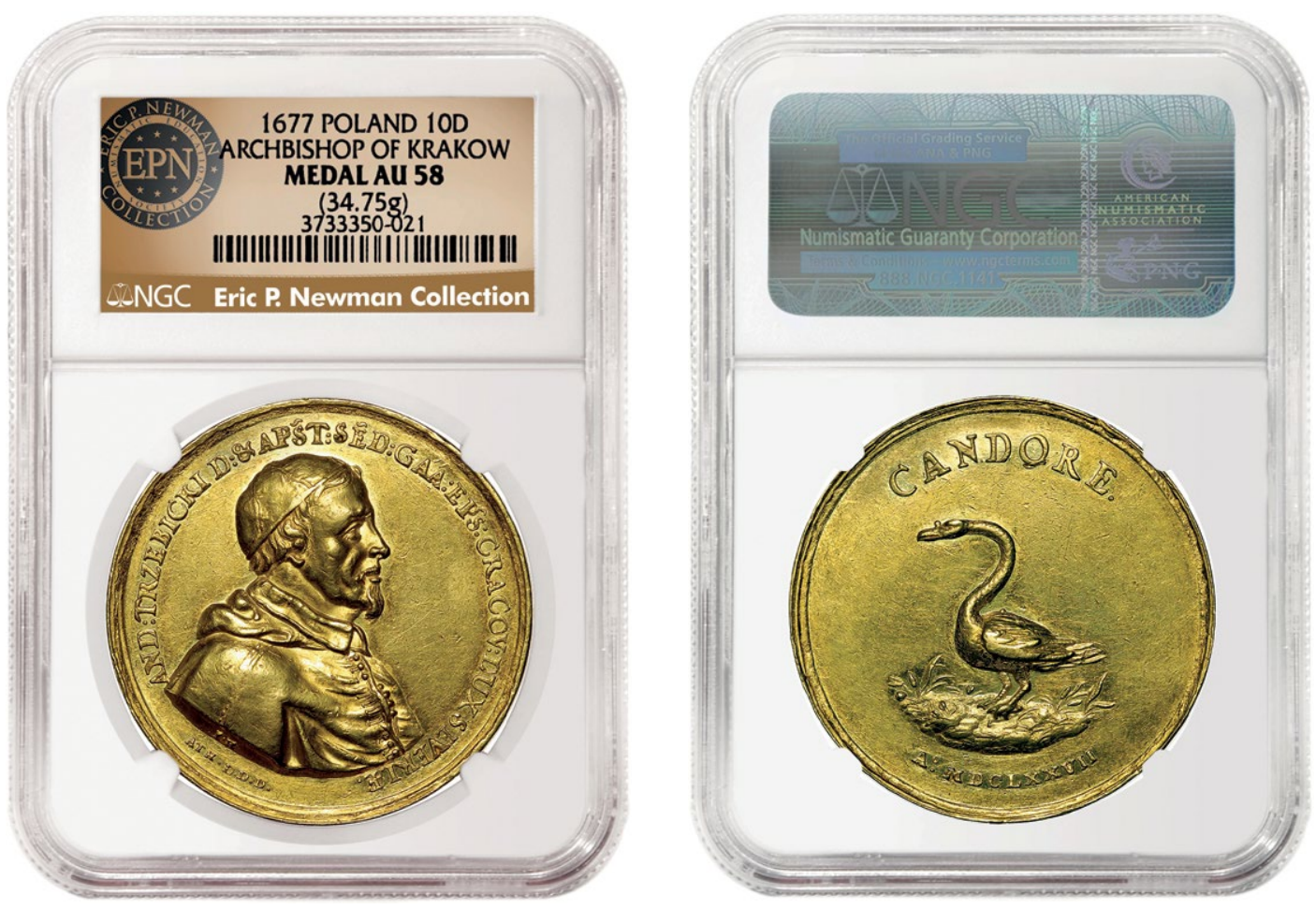

3.Johann Hohn Mt. Medal biskupa Andrzeja Trzebickiego, awers i rewers, złoto, 1677 r., Gdańsk, egzemplarz z kolekcji Erica Pfeiffera Newmana sprzedany na 3029. aukcji Heritage Auctions w Nowym Jorku (Eric P. Newman Collection Wortis Signature Auction), 1412014 r. Fot. https://coins.ha.com/itm/poland/ world-coins/poland-andrzej-trzebicki-medallic-gold-10-ducats-1677-/a/3029-

30233.s?ic4=ListView-ShortDescription-071515-new

ge-auctions/; https://www.ngccoin.com/gallery/ , 41mm, 34.752g, AU58 NGC Boldly struck and lustrous, with extremely high relief. The obverse has a portrait of Andrzej Trzebicki (Bishop of Krakow) facing right, while the reverse has a rather whimsic image of a goose facing left, with the date below in with the mint at Danzig, and also with various other German mints. We can find no record of an example in gold, either at auction, or in numismatic reference books. Exceedingly rane, and certain to be one of the sale of world coins" https:/coins hacm/itm/ oland/world-coins/poland-andrzej-trzebicki-m lic-gold-10-ducats-1677-/a/3029-30233.s?ic4-ListView-ShortDescription-071515-new Idostęp 18 XI 2016]; https://nnp.wustl.edu/library//mageDetail/583772; https:://nnp.wustl.edu/library//mageD unikatoweso okazu zauważono także w wolskich kręgach numizmatycznych, np. na portalu O monetach.pl: http://omonetach.pl/aktualnosci//6/8113/medal-andrzej-trzebnicki-herbu-labedz był wcześniej w posiadaniu innego prominentnego amerykańskiego kolekcjonera numizmatów, Edwarda Howlanda

Robinsona Greena (1868-1936), którego spuściznę nabył w większości Burdette Garner Johnson (1885-1947), prowadzący firmę St. Louis Stamp \& Coin Company, wybitny numizmatyk i mentor młodego Newman Egzemplarz srebrny znajduje się w gabinecie numizmatycznym Biblioteki Narodowej w Paryżu. Co godne odnotowania, podano przy nim informacje o akcesji do zbioru przed $1689 \mathrm{r}^{29} \mathrm{Tak}$ wczesna data wskazuje, że być moze zostat on pozyska w Polsce zrzez ambasado Ludwika xiv w Polsce przez an basadora Ludwika XIV lub innego dyplomatę francuskiego, dzia jącego w otoczeniu Jana III Sobieskiego. Kwestia zasługuje na dalsze badania.

$29 \mathrm{Nr}$ inw. Pol. 128, średn. $4,2 \mathrm{~cm}$, waga $30,75 \mathrm{~g}$, http: $/ /$ medaillesetantiques.bnf.fr/ark:/12148/c33gbllwn2 
Medal wybity w srebrze znajdował się również w wielkiej kolekcji numizmatycznej króla Prus, Fryderyka I, w zamku berlińskim ${ }^{30}$. Niestety, nic nie wiadomo o okolicznościach znalezienia się numizmatu w królewskiej kolekcji. Odnotowana jest też jego obecność w zbiorze Heinricha Lübecka w Królewcu ${ }^{31}$. W literaturze zareje strowano istnienie dalszych sztuk $\mathrm{z}$ tego kruszcu: w kolekcji Jakuba Reichla w Petersburgu ${ }^{32}$ oraz w posiadaniu Piotra

\section{L. Beger, Numismata pontificum Romanorum,} aliorumque ecclesiasticorum rariora \& elegantiora: ex areque expressa \& diblogo illustrata, Colco, sele Brandenburgicae 1704, s. 75-76, il. na s. 75 .

31 G.B. Casseburg, Sammlung preussischer und polnischer Medaillen wieauch Thaler welche auf allerhand Begebenheiten geschlagen und von Seel. Herrn Heinrich Lübeck [...] colligiret, in ihrer Ordnung vorgestellt und kürzlich beschreelben, Konigsberg-Leipzzig 1737, s. 55 poz. 29. "Auf den Bischof in Krakau Trzebicki mit Apost. Sedis Gan. Eps. Cracov. Dux Sever. Unten A. F. H. d.d.d. Rev. Ein Schwan mit der Umbschrifft candore unten MDCLXXVII". Katalog podzielony jest wedłu panowania władców pruskich, a następnie królów Sobieskieso. Heinich Lübeck (1672-1736) byt raina III skim Królewca i nadzorca wagi (Waage-Inspektor) w Knipawie; jego kolekcja po śmierci syna i spadkobiecy Johanna Heinricha (1716-1780) została sprzedana w $1781 \mathrm{r}$. Verzeichiß der vorzü̈lich vollständigen Sammlung von Medaillen und Thalern die zum Nachlaß gehören und den 10 ten Sept. 1781. durch eine [] öffentliche Ausbiethung, denen Münzlieberhabern iberlassen werden sollen, Konigsberg [1781]; Johan Christoph Gottsched Briefwechsel unter Einfluß des Briefwechsels von Luise Adelgunde Victorie Gottsched, E. Menzel, R. Otto, M. Schlott, Berlin-Boston 2019, s. 199, przyp. 10.

32 J. Reichel, Die Reichelsche münzsammlung in St. Petersburg, t. 2: Liefland, Curland und Polen, [St. Petersburg] 1842, s. 317, poz. 2705 (z oznaczeniem rzadkości R4). Jakob von Reichel (1780-1856), urodzi się Warszawie jako syn medaliera Jakoba Reichlast, wyjechał z nim do Petersburga gdzie osiadt pracował jako grawer i malarz miniatur; jego kolekcja zakupiona w latach 1857-1861 przez cara Mikołaja I (41875 sztuk) stała się istotną c zęścią
Umińskiego w Krakowie (eksponowana na wystawie jubileuszowej odsieczy wiedeńskiej w r. 1883)33. Na 66. aukcji zorganizowaMenem 6 maja 1930 r. pojawił sie kolejyy medal Trzebickiego, który w katalogu określono jako: „Schönes Original dieser selten Med". Szacunkowo wyceniono go na 200 marek niemieckich ${ }^{34}$. Los wymienionych egzemplarzy oraz określenie miejsca ich obecnego przechowywania wymaga dalszych badań.

Nieznana jest liczba późniejszych kopii medalu. Galwanostatyczną kopię w dwóch częściach (a więc najpewniej osobne odlewy awersu i rewersu) posiadał Zygmunt Chełmiński w Szarawce na Podolus. Nowszy odlew znajduje się

tycznego Ermitażu. B.-K. Koehne,Jacob v. Reichel und seine Sammlung, ,Zeitschrift für Münz-Siegel und Wappenkunde. Neue Folge" 1859-1862, s. 1-24; $Я_{k}$ Реихель - медальер коллекиионер, ученый (1780-1856)

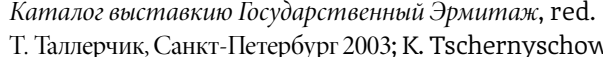
Die deutschen Münzen aus der Sammlung Jacob von Reichel, „Beiträge zur Brandenburgisch/Preussische Numismatik", Numismatisches Heft 2011, nr 19, s. 55-58; https://bioslovhist.spbu.ru/histschool/ $2245-$

3 Wystawa Sobieskiego w Krakowie (ciagg dalszy), ,Gazeta do Polski odnoszace się..., dz. cyt., s. 104, poz. 1091. 34 Adolph E Cahn Frankfurt am Main Niedenou 55 Versteigerungskatalog Nr. 66. I. Sammlung Antiker Münzen Griechen, Römer, Byzantiner und Barbarenmünzen, Nachlaß eines ausländischen Adligen. II Sammlung Russischer Münzen enthaltend viele und Medaillen Europäischer Länder aus verschidenem Besitz. Anschliessend Auktion 67 Nuismatische Bibliothek des verstobenen Herrn Geheimrat Prof. Dr.h.c. Ferdinand Friedensburg. Die Verstiegerung findet im Auftrag der Besitzer statt Dienstag, 6 Mai München 1930, s. 158, poz. 2467, tabl. 47.

35 Auctions-Catalog. Sammlung des Herrn Sigismund von Chelminski, Szarawka (Russland). Münzen und Gepräge. Montag, den 25. April 1904 und folgende in Locale und unter Leitung des Experten, Otto Helbin również w Gabinecie Numizmatycznym Muzeum Lubelskiego ${ }^{36}$. Warto dodać, że w spuściźnie Władysława Bartynowskiego, który prowadził kartotekę portretów polskich, odnotowane zostało istnienie graficznego odwzorowania medalu krakowskiego biskupa ${ }^{37}$. Dziełem tego badacza jest również dokumentacja numizmatu wykonana według własnej metody, tzw. bartynotypu, w jednym $\mathrm{z}$ albumów poświęconych numizmatom, zachowanych w Bibliotece Narodowej w Warszawie ${ }^{38}$. Bardzo szczególnym przejawem recepcji omawianego medalu jest również ilustracja przedstawiająca popiersie biskupa Andrzeja Trzebickiego stylizowane na płaskorzeźbe kamienną. Została ona zamieszczona w historycznej pracy Ludwika Kubali z 1917 r.39 Stan badań nad interesującym nas medalem Andrzeja Trzebickiego ogranicza się do kilku publikacji o charakterze katalogowym oraz wzmianek na marginesie szerszych opracowań. Numizmat pojawił się wcześnie w kregu zainteresowań historioweześ i wrón się drukiem komentarz pióra Lorenza Begera, tak interesujący, że przyjdzie do

1904, s. 129, poz. 1887. Antoni Zygmunt Chełmiński 863-1905), wasciciel jednej z największych polski sprzedaż w domu aukcyinym Ottona Helbing wr. 1904. M. Gumowski, Kollekcya monet imedal P. Z. Chetmińskiego z Szarawki, „Wiadomości Numizmatyczno-Archeologiczne", t. 15, 1904, nr 1, szp. 79-81; nekrolog w: ,Wiadomości Numizmatycz-
no-Archeologiczne", t. 16, 1905, nr 3 (63), szp. 335; M. Gumowski, Chelmińshi Antoni Zygmunt, wi: Polshe stownik biograficzny, t. 3, Kraków 1937, s. 278. 36 M. Koperwas, Katalog medali XVI-XVIII w. w wbiorach
Gabinetu Numizmatycznego Muzeum Lubelskiego, Lublin 1998, s. 69-70, 139 .

77 Archiwum Muzeum Narodowego w Krakowie, sygn. $802 / 60 / 0$.

38 Biblioteka Narodowa w Warszawie, sygn. AFG.27/III, I.G.20.900

9 L. Kubala, Wojna brandenburska i najazd Rakocze niego wrócić w dalszym wywodzie 4 . Informacje o medalu zamieścił Gottfried Bernhard Casseburg ${ }^{41} \mathrm{w}$ opracowaniu

z 1737 r., zatytułowanym Sammlung preussischer und polnischer Medaillen wie auch Thaler, będącym spisem kolekcji zgromadzonej przez Heinricha Lübecka ${ }^{42}$. Medal krakowskiego biskupa znany był też Johannowi Christianowi Kundmannowi ${ }^{43}$, który zebrał w swoim gabinecie przeszło 3000 okazów sztuki medalierskiej. Praca jego autorstwa Die Heimsuchungen Gottes in Zorn und Gnade

40 L. Beger, dz. cyt, s. 75-76, il. na s. 75. Lorenz Beger (1653-1705), wybitny numizmatyk, od 1672 r. w stużbie księcia Palatynatu Karola I Ludwika
organizował gabinet numizmatyczny w Heidelberg organizował gabinet numizmatyczny w Heidelber
w 1686 r. objął posadę bibliotekarza na dworze W 1686 r. objął posadé bibliotekarzana dworze
Fryderyka III (póziniejszego króla Fryderyka I) w Berlinie, gdzie nadzorował gabinet sztuki i starożytności, w tym zbiór numizmatów, w 1703 r. urzaddzony w nowym zamku berlińskim, wznies
nym według projektu Andreasa Schlütera; był nym według projektu Andreasa Schlutera; był
autorem erudycyjnych, wysoko ocenianych pra

z zakresu numizmatyki, medalierstwa i starożytności F. Kenner, Beger: Lorenz B., w: Allgemeine Deutsche
Biographie, Bd. 2, Leipzig 1875, s. 271-272; Lorenz Beger, w: L. Noack, J. Splett,Bio-Bibliographien: brandenburgische Gelehrte der frühen Neuzeit, Berlin-Cölln $1688-1713$, Berlin 2000, s. 37-44; V. Heenes, Biographie und Bibliographie von Lorenz Beger, w: Procerus Brandenburgicus", hrsg. von M. Kunze, H. Wrede, Münich 2006, s. 83-96. O zbiorze, G. Heres, Die Anfänge der Berliner Antiken-Sammlung zur Geschichte des Antikenkabinetts 1640-1830, ,Staatliche Museen zu Berlin. Forschungen und Berichte" 1977, nr 18,
s. 93-130, tabl. 21-28; tenże, Die Anfänge der Berliner Antiken-Sammlung zur Geschichtedes Antikenkabinetts 1640-1830. Addenda et corrigenda, Staatliche Museen zu Berlin. Forschungen und Berichte" 1980 nr 20, s. 101-104.

4 Gottfried Bernhard Casseburg (1708-1750), prawnil od $1730 \mathrm{r}$. asystent w bibliotece miejskiej i profestor filozofii, od $1740 \mathrm{r}$. profesor starożytności n edu/FacStaff/SSNaran//Kant/Bio/BioKonFrames. html [dostęp $14 \mathrm{~V} 2020]$

42 G.B. Casseburg, dz. cyt, s. 55 , poz. 29

43 Johann Christian Kundmann (1684-1751), lekarz i numizmatyk wrocławski, zgromadził kolekcie monet oraz dzieł natury i sztuki. A. Schimmelpfennig,
Kundmann, Johann Christian w: Allgemeine Deutsche. dz. cyt.. t. 17, Leipzig 1883, s. 377. 
Uber das Hertzogthum Schlesien in Müntzen, wydana w roku 1742 w Lipsku, zawiera spi dziewięciuset osobistości upamiętnionych

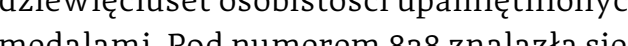
notka: „Trzebicki, (Andreas) Dei et notka: „Trzebicki, (Andreas) Dei et Apostolicae sedis gratia Episcopus Cracoviae, Dux Severiae in effig. Rev. Candore. $1677^{\prime 44}$. Niestety, wśród egzemplarzy wybranych do reprodukcji na dołączonych do wydawnictwa sześciu tablicach brak medalu krakowskiego hierarchy. Feliks Bentkowski w 1830 r. w spisie zbiorów Gabinetu numizmatycznego Uniwersytetu Warszawskiego podał wagę znajdującego sie w ty zhiorze zlotego zemplarza (1o dukatów), przy toczył też widniejące na awersie inicjały: I.H oraz W swoim wiekopomnym Gabinecie medalów polskich Edward Raczyński zamieścił obszerną notę o zajmującym nas medalu w tomie drugim, w dwóch kolejnych wydaniac z 1838 i 1845 r. ${ }^{46}$ Rozpoznał prawidłowo autora dzieła, Johanna Höhna Mł pozostawit tora dzie to jo Rozpoznat prawidowo sie do postici tabe się do postaci labędzia na rewersie, skonstatował, ze ptak ow „,jest herbownym znakiem, a przytem allegoryczną figurą oznaczającą prawość serca i rzetelność". Kilka słów poświęcił również samemu Andrzejow Trzebickiemu ${ }^{47}$. Do podstawowych danych opisowych (bez rozpoznania medaliera i rozwiązania skróconych inskrypcji) ograniczył się także Leon Mikocki w niemieckojęzycznym, wydanym w roku 1850

w Wiedniu, katalogu polskich monet

$$
\begin{aligned}
& 44 \text { J.Ch. Kundmann, Die Heimsuchungen Gottes in Zorn } \\
& \text { und Gnade Uber das Hertzogthum Schlesien in }
\end{aligned}
$$

i medali ${ }^{8}$. Podobnie postąpił Dmitrij Iwanowicz Prozorowski publikując w 1872 r. Petersburgu katalog medali polskich, strowany wizerunkami odbitymi z zarekwirowanych w Warszawie płyt graficznych ${ }^{49}$. Opracowanie Raczyńskiego wykorzystał Konstanty Hoszowski w monografii krakowskiego biskupa, wydane w Krakowie w roku 1861. Napisał ogólnikowo: „na lat dwa przed śmiercią czcigodnego Pasterza, wdzięczność publiczna oceniając jego niezliczone dla kraju zasługi, uczciła pamięć rzadkich cnót i poświęceń, pięknym medalem, wybitym na wiekopomną sławe

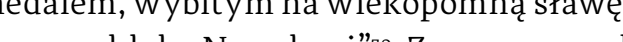
jemu, a chice Na rozwlązanie sygl „ATH D.D.D. jako. "An cat" ${ }^{15}$. Stwierdził też, że łabędź jest rodowym znakiem domu Trzebickich, , , przytem postaciowem wyobrażeniem

nieskazitelnej czystości serca, jaką przez całe życie swoje odznaczał się biskup ${ }^{52 "}$. Towarzyszącą mu lemmę tłumaczył tak: Candore; to jest: białością (a w przenośnem "Cance to jest: bia . (c) drugim wydanym w Petersburgu w r. 1872, medal bity w srebrze, oznaczony został numerem 4050. Autor podał nazwisko medaliera, litery ATH pozostawił nierozwiązane z sugestią, że dotyczą ofiarodawcy, natomiast „D.D.D.” zostały odczytane jako „Dat,

48 L. Mikocki, Verzeichniss einer grossen und sehr gewählten polnischen Münz-u. Medaillen-Sammlung, , s. 140, poz. 2897

49 Д.И. Прозоровский, Колтекиия хранячиися
в императорской Академии художеств гравор на меди ирезьбь на дереве, с изображением медалеи, исторических событиии игербов. Гравюры, Санкт Петерсбург. 1872, opisany jo zhoty is obmy). 50 K. Hoszowi, dz cyt, s. 111

51 Tamże, s. 112

52 Tamże, s. 112-113.

53 Tamże, s. 112
Dicat, Dedicat"54. Pełen opis, z prawidłową atrybucją oraz rozwinięciem inicjałów na rewersie za krakowskiego biskupa pióra Mariana Bartynowskiego w Encyklopedji kościelnej z 1907 r. Autor posłużył się zgrabną, lecz w istocie nic nie znaczącą formułą: „wdzięczność publiczna oceniając jego niezliczne dla kraju zasługi, uczciła na lat dw przed zgonem $T$. jego zasługi wybiciem medalu"s5.

Michał Rożek uwzględnił meda w biografii biskupa Andrzeja Trzebickiego z 1989 r., napisanej wspólnie z Adamem Przybosiem. Poza krótkim opisem, stwierdził, że został on wybity „przez miasto Kraków w 1677 r.", w dowód uznania dla "wybitnego męża”. Nie podał przy tym żadnej podstawy źródłowej dla takiej konstatacji. Od dziewiętnastowiecznego monografisty biskupa przyjął odczyt inicjałów poniże popiersia biskupa ${ }^{5}$. Niczego nowego nie wniosła notka dotyczaca eszemplarza w zbiorach krakowskiego Muzeum Narodowego, autorstwa Danuty KrawczykBiernat, w publikacji z 2012 r. Autorka wskazała, że „Napis Candore, odnoszący się

\begin{tabular}{|c|}
\hline $\begin{array}{l}\text { 4. E. Hutten-Czapski, dz } \\
\text { (srebro, } \mathrm{R}^{\prime} \text { ). }\end{array}$ \\
\hline $\begin{array}{l}55 \text { Encyklopedja kościelna..., dz. cyt., t. 29, Warszawa } \\
\text { 1907, s. } 236 \text {. }\end{array}$ \\
\hline 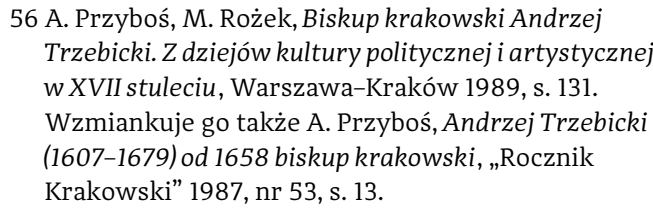 \\
\hline $\begin{array}{l}77100 \text { rarytasów..., dz. cyt., s. 172, poz. } 74 \text { (oprac. } \\
\text { D. Krawczyk-Biernat). }\end{array}$ \\
\hline
\end{tabular}
do nieskazitelnej bieli ptaka, okazuje przymioty biskupa". Monogram ATH nie został rozszyfrowany, wskazano jedynie, że „należy zapewne do fundatora medalu"s7. Podstawowe informacje oraz dobrej jakośc fotografie dostepne sa w cyfrowej bazie zbiorów muzealnych ${ }^{58}$. Medal Andrzeja
Trzebickiego wzmiankowany jest także w biogramach Johanna Höhna $M+{ }^{59}$ Dodac można, że medal (egzemplarz w Muzeu Narodowym w Krakowie) posłużył również jako ilustracja do opracowania nowożytnych dziejów Krakowa pióra Janiny Bieniarzówny i Jana $M$. Małeckiego ${ }^{60}$. Autorstwo medalu, potwierdzone monogramową sygnaturą, nie budzi wątpliwości. Jest on dziełem wybitnego artysty gdańskiego, Johanna Höhna Mł. (ok. 1642 Gdańsk - 26 XI 1693, Wrzeszcz). Był on synem medaliera, Johanna St., u którego uczył się zawodu. Samodzielnie pracował przynajmniej

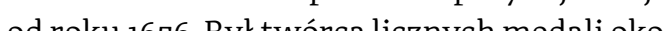
licznó́ciowych iportetowych, takze dlazleceniodawców spoza Gdańska, głównie króla Polski, elektora brandenburskiego i senatorów Rzeczpospolitejej. Spod jego ręki wyszły numizmaty związane z krakowskimi uroczystościami koronacyjnymi Jana III Sobieskiego

VII-MdP-1094. https://zbiory.mnkpl/pl/wyniki-wyszukiwania/katalog/200161 [dostep 23 III 2020]

59 M.in. L. Forrer, Biographical Dictionary of Medallists, Coin-, Gem-, and Seal-Engravers, Mint-Masters, \&c., with references to their works B.C. 500 - A.D. 1900 , t. 7 London 1923, s. 454

60 J. Bieniarzówna, J.M. Małecki, Dzieje Krakowa. s. 393

$61 \mathrm{M}$. Gumowski, Studia nad gdańska sztuka medaliersk ne" 1924, nr 10, s. 23-64: tenże, Gdańska sztuba" medalierska, w: Gdańsk. Przeszłośći iteraźniejszość, red. S. Kutrzeba, Lwów 1928, s. 440-452; tenże, Höhn Jan, w: Polski słownik biograficzny, t. 10, WroctawWarszawa-Krakow 1962-1964, s. 49; Stownik artystów polskich iobcych w Polsce dilatajacych (zmartych przed J. Maurin-Białostocka, J. Derwojed, Warszawa 19 s. 94-95; J. Strzałkowski, Słownik medalierów polskich iz Polska zwiazanych (1508-1965), Warszawa 1982, s. 96-98; A. Wieccek, dz. cyt, s. 63-66, il. 78, 80-84
(autor nie wzmiankuje medalu Andrzaja Trobicher (ator nie wzmiankuje medalu Andrzeja Trzebickie so), M. - G0; Polski indeks biograficzny, wyd. 2. połączone i rozszerzone, oprac. G. Baumgartner, München 2004, s. 552; http://www.gedanopedia.pl/gdansk/?title=H\%C3\%96HN_JOHANN_jr, oprac. M. Glińs 
i Marii Kazimiery w lutym 1676 r.6. ${ }^{62}$ a także złota moneta z 1677 r. z królewskim wizerunkiem z jednej i widokiem Krakowa $\mathrm{z}$ drugiej strony ${ }^{63}$.

Nic nie wiadomo o okolicznościach powstania medalu: przyczynie, inicjatorze, fundatorze, liczbie egzemplarzy, sposobie dystrybucji. Proces powstawania tego typ numizmatów miał charakter złożony. Aby przybliżyć działania, które trzeba było podjąć, żeby zrealizować dzieło niewielkie rozmiarami, lecz odznaczające się często wybitnymi walorami artystycznymi,

a jednocześnie pełniące ważne funkcje propagandowe, przytoczymy dobrze udoku-

mentowany źródłowo przypadek. Dotyczy on co prawda epoki saskiej, ale może świetnie zilustrować mechanizmy działające z pewnością także w drugiej połowie XVI w. Chodzi o medal jubileuszowy wybity w złocie i srebrze z okazji 300. rocznicy inkorporacji Prus do Polski ${ }^{6}$. Pomysł wyszed od burmistrza Gdańska, Johanna Wahla. Po zatwierdzeniu go przez radę miejską zakupion u zlotnikow srebro wagi 286 grzywien $\mathrm{i}^{1 / 2} \mathrm{sk}$ Do wykonania projektu zatrudniono Johanna Donneta. Rysunek przeniósł na stempel menniczy rytownik Gottfried Schwartz, za co zapłacono znaczną kwotę. Wiadomo z archiwaliów, że wybito 5 złotych i 286 srebrnych numizmatów. Nadzwyczaj cenne są również informacje na temat ich dystrybucji: złote ofiarowano członkom dworu Augusta III, srebrne ojcom miasta i pozostałym członkom

62 J.G. Rokita, Medal upamiętriający królewska koronacje Jana III Sobieskiego i Marii Kazimiery w Krakowie pochodzacy z 1676 roku. Uwagi ikonograficzne, ,

(3)

Hetps://zbiory.mnk.pl/pl/galerie-tematyczne/17/ szukiwania/zaawansowanane/katalog/64975 [dostep 23 III 2020]. Okoliczności emisji, w tym emitent, są dyskusyjine.

$64 \mathrm{E}$. Kizik, Gdański medal jubileuszowy z okazji trzechsetlecia inkorporacji Prus do Polski w 1754 roh ordynków miejskich, a także wspaniałomyślnie podarowano samym profesorom" Przeshono królowi Augustowi lll i Maril Joz Jozefie, a jedną dostał minister Henryk vo gesztowała 853 fl. 9 gr, czyli równowartość 201 łaszw pszenicy ${ }^{67}$.

Doskonale widać więc, że wykonanie medalu ku czci biskupa Andrzeja

Trzebickiego musiało także wiązać się

z wydatkami na kruszec, projektanta i wykonawce, a także ze zorganizowaniem jego produkcji. Któż zatem był inicjatorem i zleceniodawcą ? Być może odpowiedź kryje się w syglach, widniejących na awesie pod biskupim popiersim Jak juz wes siejwspomniono piensiem. Jak już wcześniej wspo„Andreas Trzebicki honor dat, donat, dedicat". Takie rozwinięcie mogłoby sugerowac, że to sam biskup krakowski kazał wybić numizmat ku własnej czci. Nie negując takiej ewentualności, trzeba wskazać, że istnieją inne możliwości. Przede wszystkim trzeba zauważyć, że litery moża czytać nastepująco: Andrea następująco: "Andrae Trzebicki honori dat, donat, dedicat". W takim przypadku mam do czynienia z dedykacją biskupowi, lecz ten, kto dokonuje tej dedykacji nie został nazwany. Taka interpretacja ma sens tylko przy założeniu, że litera $\mathrm{H}$, to inicjał słowa "honor", a skrót D.D.D. należy zwyczajowo rozwinąc jako klasyczną frazę dedykacyjną o antycznej metryce: „Dat, donat, dedicat" Literatura wskazuje jednak taki de inne warianty odczytu jednak takze nainne widerlandzkierudy ta Jan Gruyter (1560627) podaje lekcje:: „Dono dedit, donum

\section{Tamże, s. 82-85. \\ 66 Tamże, s. 85-8 \\ 67 Tamże, s. 87. \\ 68 I. Krasicki, Zbiór potrzebnieyszych wiadomości} porzadkiem alfabetu ułożonych, t. 1, Warszawa-Lwów dedit dedicavit" "ø9, podobnie Hubert Goltz: "Dono dedit dedicavit"

We współczesnym omawianemu medalowi kompendium, obejmującym objaśnienia antycznych rzymskich napisów, padewski humanista Sertorio Orsato (1617-1678) czyta skrót następująco: „Data Decreto Decurionum. [...] In lapidibus, decreto coloniae datis, sub subsequentibus”, ,Datum Decreto Decurionum”, „Datus Decreto

Decurionum. [...] Quae dicendi formula in monumentis publico decreto, in colonijs alicui erectis, quod frequentissimum”, „Datus Dono Decurionum", Decem Decurionum Dedit", Decreto Decurionum Dederunt”, ,Dono

Decurio Dedit”, a także: „De Dono Dei. Digno Deo Dicatum” oraz „Dono Dedit Dedicavit. [...] In votivis, \& Deo Dicatis" ${ }^{71}$. Nowsze leksykony abrewiatur podają następujące znaczenia: „Datus decreto Decurioni” lub „datum decurionum decreto"72, „D.D.D. Datum Decreto Decurionum. - Dat, donat, dedicat. - Dono dedit, dedicavit. Domni tres. Deo donum dedit. Dedit dedicavit"73.

Biorąc pod uwagę powyższe, należy rozważyć, czy liter D.D.D. nie należy odczytywać jako „Data Decreto Decurionum” lub podobnie. Zatem, można roboczo zaproponować wariantywne propozycje odczyt inicjałów na medalu: „Andreae Trzebick Honori Dat Dedit Dedicat” lub „Andreae Trzebicki Haec [numisma?] Data Decreto Decurionum". Można oczywiście formułować także inne warianty, ale bez mocnego

69 J. Gruterus (Jan Gruyter), Corpus inscriptionum ex Graevii Amstelaedami 1707, s. XCVIII.

70 H. Goltz, Thesaurus reia Antverpiae 1579, s. 185

71 S. Orsato, De notis Romanorum commentarius, Patav 1672, s. 132.

72 Nouveau dictionnaire de la conversation, ou répertoire universel, wyd. A. Wahlen, t. 9, Bruxelles 1845, s. 63.

73 Lexikon Abbreviaturarum. Wörterbuch lateinischer und italienischer Abkurzungen, oprac. A. Cappelli, Leipzig 1901, s. 463. wsparcia źródłami z epoki ich mnożenie wydaje się nieuprawnione.

Czy zatem określenie dekurion" mogło litej drugiej polowy XVII w? A jeślitak, to co znaczlo? Rozpoznanie ra jeprowadzone w ówczesnej literaturze wskazpowadzone w o wese resujący trop. W dziele opisującym ustrój państwa polsko-litewskiego, opracowanym przez Stanisława Krzysztanowicza i wydanym drukiem w 1642 r., natrafiamy kilkukrotnie na wspomniane określenie w odniesieniu do władz miejskich. Przytoczm je: „In civitatibus autem \& oppidis \& vicis praeter hos sunt etiam consules. Ita voca-

lantur: [podkr. - K.J. Cz., M. W.] penes quos est civitatis cujusqua gubernatio \& custodia in delinguentes animadverso: publicorum commodorum administratio, curaque edificiorum \& sartorum tectorum publicorum"74. Dalej, w odniesieniu do zarządu miasta: "Caeteros autem scabinos, ipsi consules sive decuriones $[p o d k r .-K J, C z, M, W]$ in sua quinque civitate $\&$ oppido legunt, \& sua gungre civitate \& Sacramento adigunt", „Ea vero partim penes advocatum \& scabinos, partim penes decuriones sive consules [podkr. K.J. Cz., W.] \& magistratum civium sunt, partim etiam penes magistros contuberniorum"76. W końcu, opisując miasta na Warmii: "Civitates a decurionibus, seu consulibus, [podkr. - K.J. Cz., M. W.] \& quidem Germanicae linguae \& sanguinis [...] reguntur"77. Najwyraźniej więc w opracowaniach prawniczych, w nawiązaniu do nomenklatury antycznej, dekurionami nazywano rajców miejskich. Medal Andrzeja Trzebickiego na wielu poziomach odwołuje 74 S. Krzysztanowicz, Respublica sive status Regni
Poloniae, Litvaniae, Prussie, Livoniae, Lugduni

75 Tamże, s. 16

77 Tamie, s. 211. 


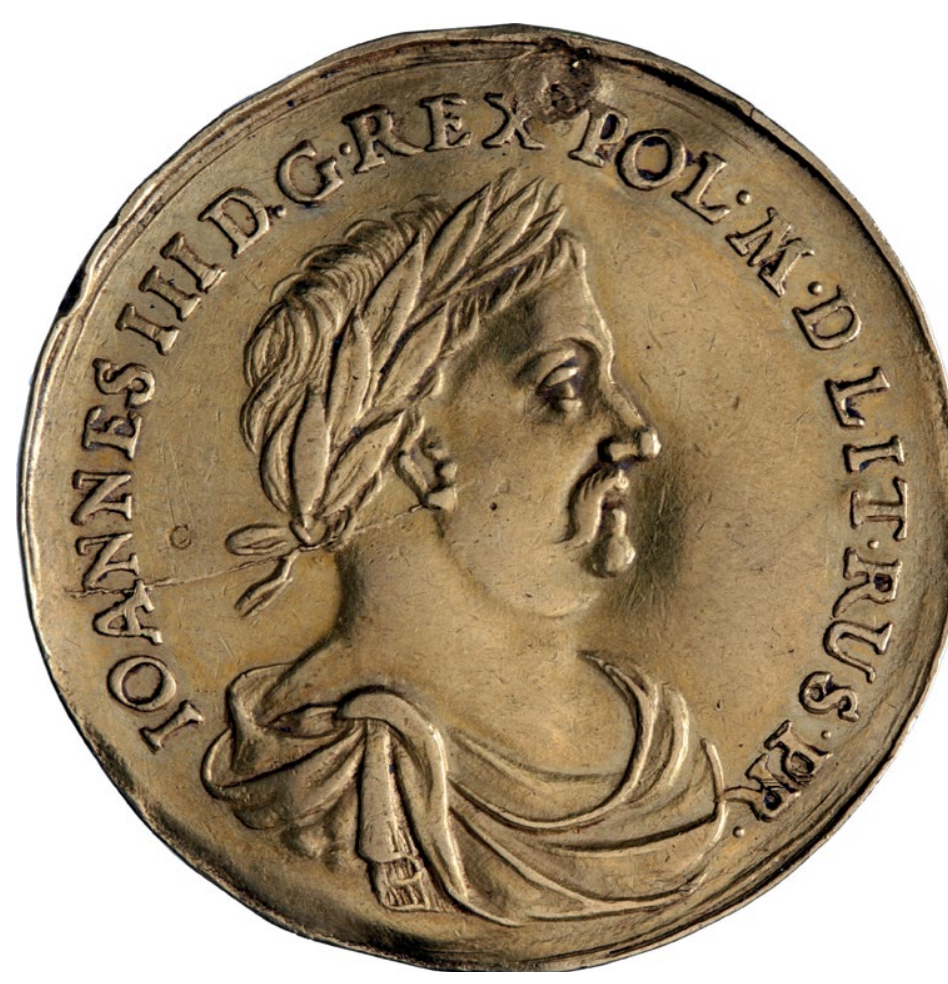

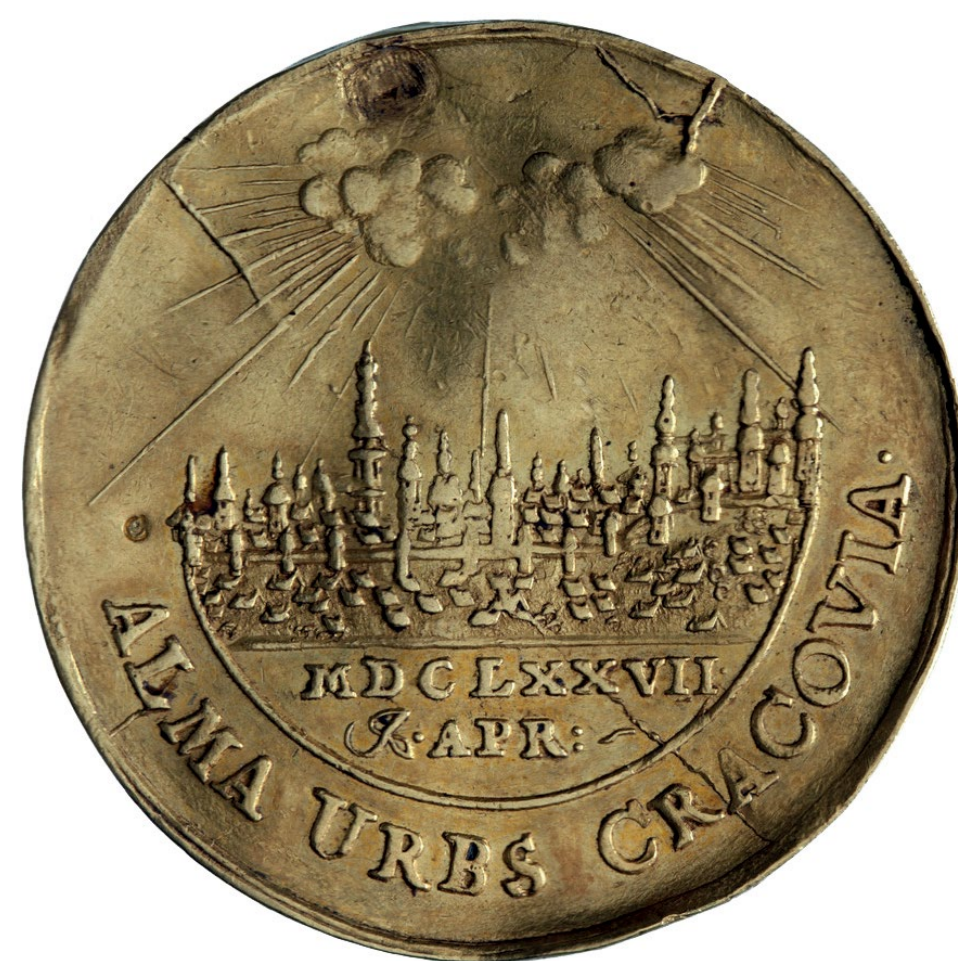

4. Johann Höhn Mł., Donatywa krakowska Jana III, awers i rewers, złoto, 1677 r., egzemplarz w Muzeum Narodowym w Krakow Fot. MNK się do erudycji odbiorców, wśród których najpewniej był osoby znające okolicznośc jego powstania oraz sam biskup. Tak więc stwierdzenie Michała Rożka, że rada miejska Krakowa była podmiotem odpowiedzialnym za powstanie numizmatu, jest godne rozpatrzenia.

$$
\text { Mimo słabego zaawansowania ba- }
$$
dań, wiadomo, że w kręgu krakowskich władz miejskich powstawały różnorakie inicjatywy z zakresu mecenatu artystycznego i kulturalnego ${ }^{78}$. Należały do nich, nie zawsze uwieńczone sukcesem, działania w zakresie gromadzenia i publikowania źnóder mu grcyplnych, a takż badania źródel municypalnych, a także badania nad dziejami stolicy Królestwa. Ze względu na charakter przedstawienia na rewersie medalu, szczególnie istotne znaczenie mają świadectwa praktycznej twórczości na polu emblematyki. Poza programami eksponowanymi na okazjonalnych bramach triumfalnych ${ }^{79}$, zwracają uwagę złożone pod względem układu i treści kompozycje na kartach tytułowych Septimanaliów" (rachunków miejsich) z lat 1665-1669, których aukow miejskich z lat 1665-1669 kiorych auz nich, z 1665 r., widnieją nawet cztery medaliony z emblemami i lemmami, mające cechy odrysów z monet i medaliso. Co prawda, nie ujawniono dotąa źródeł,

\section{M. Rożek, Mecenat mieszczaństwa krakowskiego} wXVII wieku, Kraków 1977, s. 183-212

79 Autorstwo tych programów stanowi odrębne zagadnienie, bowiem wich realizacji brali udział profesorowie Akademii Krakowskiej, np. autorem
literackiej oprawy wjazdu koronacyinego Jana III Sobieskiego w $1676 \mathrm{r}$. był Stanisław Józef Bièzanowski. In laudes Ioannis Sobescii. Rękopiśmienny zbiór emblematów z rysunkami Johanna Jakoba Rollosa, wstęp i oprac. M. Górska, B. Milewska-Waźbińska, Warszawa 2016, s. 34.

80 M. Rożek, Mecenat..., dz. cyt., s. 201, il. 63-66. Kwestia realnych pierwowzorów dla tych kompozycii że dwie połączone rece zlemma: Felicitas Tempora Regum Concordia" występują na medalu króla Hiszpanii Filipa II z 1559 r.; słońce i księżyc oraz korona z lemmą „Tam Feliciter Omnia” odnoszą się poświadczających emisję numizmatów przez radę miejską, ale można być pewnym, że istniała wśród krakowskich rajców świadomość korzyści płynących z takich działá prowadzonych przez inne miasta głównie Gdańsk. Funkcję medali w polityce prowadzonej przez miasto nad Motławą scharakteryzował trafnie Marcin Kaleciński: „Monety, medale i donatywy bite w Gdańsku stanowiły istotne medium propagandowe, oręż w walce o podtrzymanie szczególnego statusu Gdańska - w przekonaniu jego mieszkańców - podległego jedynie królowi. Mimo niewielkiego form cynich konografla tych pzed ión, jak swoisty barometr, ży wo reagowala na aktualną niunkturę polityczną. Medale chwały i wierności Gdańska, chwały władców polskich, z racji precyzji i lapidarności formy oraz erudycyjnej treści należą do wybitnych w skali europejskiej zjawisk z pogranicza sztuki i polityki"

Dopóki nie zostaną odnalezione zapisy archiwalne, poświadczajace zaangażowanie krakow kich whadz miejskich na polu mennictwa, dopóty można jedynie za dotychczasową literaturą wiązać z nimi monetę (znane są egzemplarze złote o wadze 3, 4 i 5 dukatów oraz w srebrze) datowaną na kwiecień (?) 1677 r., określaną czasem mianem donatywy ${ }^{82}$. Na jej awersie widnieje popiersie Jana III Sobieskiego all'antica, w paludmencie i wieńcu laurowym, na rewersie zaś panorama Krakowa oświeconego promieniami padającymi z obłoków (il. 4). Na uwage zasługuje rewersowy napis: ALMA URBS CRACOVIA" $z$ datą:

81 M. Kaleciński, Między sera prywatna a publiczna. "Ars mythologica"i antykizacja we wnętrzach domów antyczny, red. M. Otto, J. Pokrzywnicki, Gdańsk 2017, s. 143.

82 O definicii donatywy zob. I. Tylicki, O historii sztuki i numizmatyce, czyli kto projektował niektóre donatywy gdanskie Zygmunta III,
„MDCLXXVII / \& (?). APR:" ${ }^{83}$. Numizmat przypisuje się Johannowi Höhnowi Mł. ${ }^{84}$ Nie rozwijając szerzej interpretacji tego bardzo interesuiącego dzieła trzeba pod-

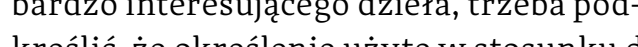
kreslic, że okreslenie użyte w stosunku do Kaco łuje się bezpośrednio do nomenklatury odnoszonej do Rzymu ${ }^{85}$. Król, którego

83 E. Raczyński, dz. cyt., t. 2, Wrockaw, s. 297, poz. 211; E. Hutten-Czapski, dz. cyt., poz. 2424. Charakterystyka przy okazji sprzedaży egzemplarza monety
czterodukatowej 14 III 2020 r. w Antykwariacie

czterodukatowej 14 III 2020 r. W Antykwariacie
Numizmatycznym Michał Niemczyk w Warszawie, http://archiwum.niem czyk.pl/auction/51/692/

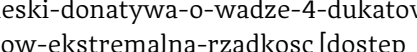
$23 \mathrm{~V} 2020$ ]: „Jest to jedyna znana donatywa koronna. Została wybita przez radę miasta Krakowa, choć nie jest jasne, z jakiejo okazii wybito ją właśnie w 1677
roku. Król bowiem w 1677 roku wizytował Prusy w tym Gdańsk. Nie gościł natomiast w tym rokku, w Krakowie. Niewykluczone jednak, że król nadał miastu jakieś nowe przywileje. Raczyński (za Albertrandim) przypuszczał, że donatywa ta powstała w zwiazzku z planami królewskimi otwarcia mennicy podeimowane byly starania o otwarcie mennicy w 1677 roku. Zgoda na otwarcie mennicy zapadła ostatecznie na sejmie zwołanym w Grodnie. Donatywa została wybita na polecenie króla dla celów podarunkowych. Rozdawano ją posłom i senatoro Być może włáśnie ten królewskki dar zapewnit obradującego w Grodnie sejmu. Donatywa wybita została jedną parą stempli, ale w trzech nominałach; o wadze trzech, czterech i pięciu dukatów. Większośc znanych egzemplarzy to trzydukatówki. Pozostałe nominały są ekstremalnie rzadkie. $\mathrm{W}$ zbiorze

Egremplarz złoty 0 wadze 4 lub 5 dukatów jest w zbiorach Ermitażu. Koleiny egzemplarz znajduje się w kolekcji cesarskiej w Wiedniu". Trzydukatowa wersja została sprzedana 21 X 2017 r. w tym samym domu aukcyinnm. http://archiwum.niemczyk.pl/ -3-dukatow-1677-krakow [dostep $23 \mathrm{~V}$ 2020] Ostatnio pojawiło się przypuszczenie o wybici z inicjatywy rady miejskiej Krakowa złotego medalu z okazji koronacji Jana III Sobieskiego. J.G. Rokita, dz. cyt., il. I.

84 Być może znak umieszczony w obrębie daty, to nie "\&", tylko przestylizowany monogram Jh. 85 J.G.T. Grässe, Orbis Latinus. Lexikon lateinischer
geographischer Namen des Mittelalters und der Neuzeit, hrss. von H. Plechl, Zusam S.Ch. Plechl, vol. 3, Braunschweig 1972, s. 273; 
P R I V IL E G I U M

SERENISSIMI JOANNIS III, Regis Polonize, quố Sua Majeftas Liberam Electionem Confu-
lum, \& Pro.Confulum Spectabili Senarui Cracovienfi perpectuam largiri dignata eft de Annó
Domini 1677 . JOANNES TERTIUS DEI Gratia REX Polonix, Magnus DUX Lithvanix, Ruffie,
Prufsix, Malovix, Samogitie, Kijovix, Volchynix, Podolix, Podlachix, Livonix,

\section{mis}

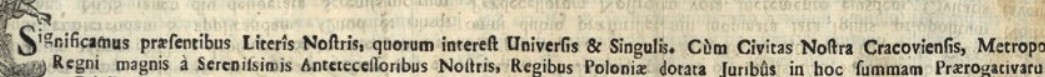

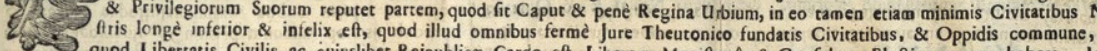

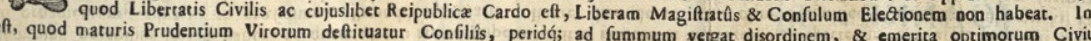

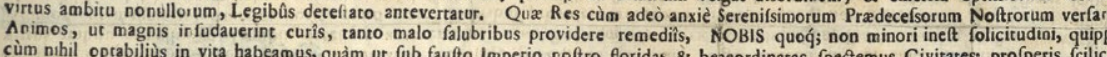

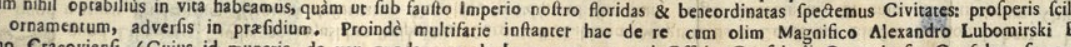

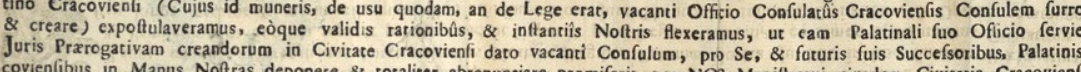

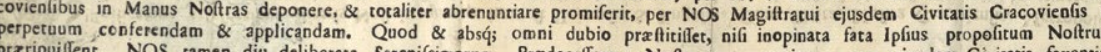

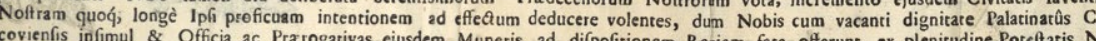

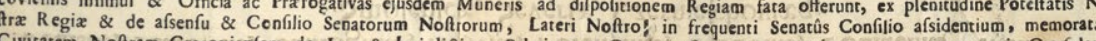

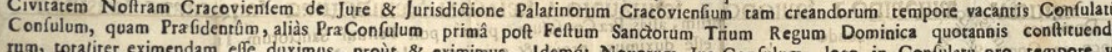

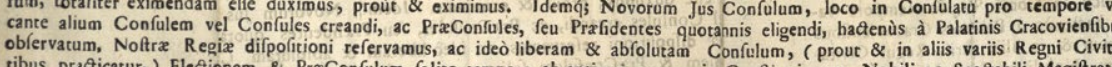

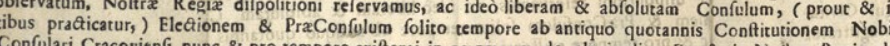

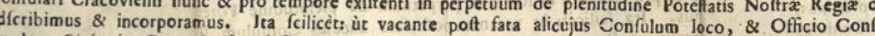

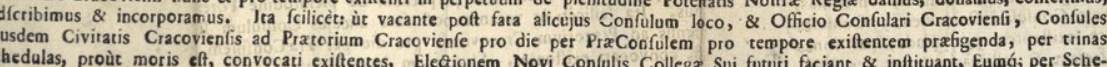

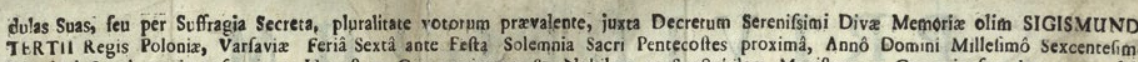

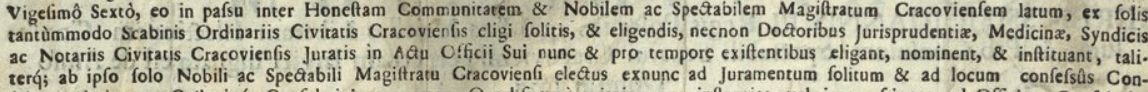

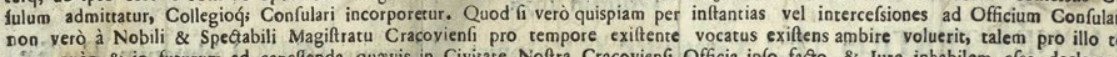

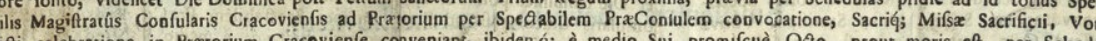

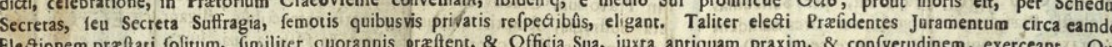

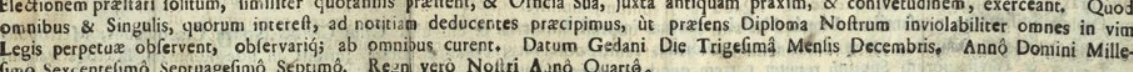
JOANNES REX

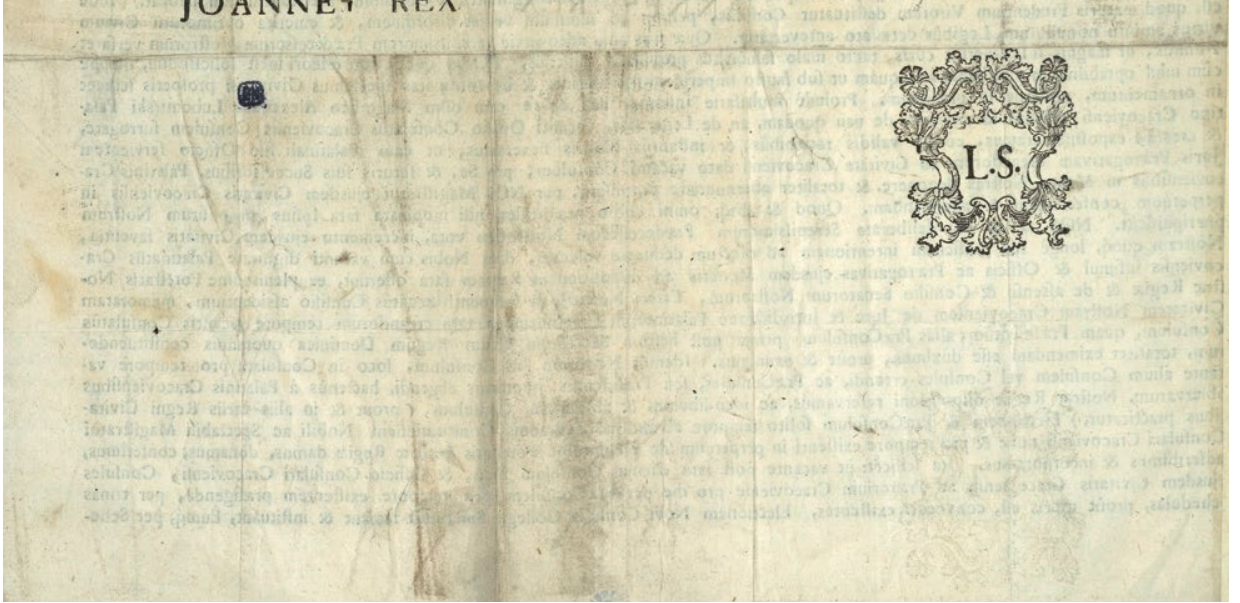

5. Edycja przywileju króla Jana III z 1677 r. dla Krakowa,

Biblioteka Jagiellońska. Fot. BI wizerunek jest stylizowany na wzór rzymskich imperatorów, był silnie związany ze stolicą królestwa, a jego nauka w murach Szkół Nowodworskich i w uniwersytecie ${ }^{86}$ także mogła stanowić przyczynę użycia terminu alma urbs" ${ }^{\prime}$

Wydaje się, że istnieją przesłanki

wzmacniające tezę o krakowskiej genezie medalu, ponieważ Andrzej Trzebicki popierał starania o uzyskanie przez władze stołecznego miasta samodzielności w wybieraniu rajców, dotąd wskazywanych przez wojewodę krakowskiego. Działo się to w 1677 r. i zakończyło wydaniem przez Jan III Sobieskiego odpowiedniego przywileju 30 grudnia tegoż roku w Gdańsku ${ }^{88}$ (il. 5). Sam biskup przypomniał o tym w liście do rady z 5 kwietnia 1679 r. ${ }^{89} \mathrm{~W}$ tym samym roku 1677 Andrzej Trzebicki aktywnie uczestniczył w obradach sejmu rozpoczętego 14 stycznia w Warszawie ${ }^{90}$. Czy mogło to być okazją do wyrażenia wdzięczności zasłużonemu senatorowi przez zoromadzon stany? Niestety, żadne znane przekazy

A. Giardina, A. Vauchez, Il mito di Roma. Da Carlo Magno a Mussolini, Roma-Bari 2008, s. $91-92$. Wywodzono to słowo $\mathrm{z}$ hebrajskiego i zrównywano w znaczeniu $\mathrm{z}$,aeterna”": ,Les Romains nommerent Rome Urbs aeterna, Alma urbs; ces deux eloges Alm lamed mem, olim, saeculum." L. Thomassin, Méthode d'étudier et d'enseigner la grammaire ou les langues. par rapporta la 'Ecriture Sainte \& à la langue Hebraĭque, t. 2, Paris 1693, s. 337.

86 H. Barycz, Lata szkolne Marka i Jana Sobieskich W Krakowie, Kraków 1939; tenże, Rzecz o studiach Wrockaw 1984.

87 Moneta wy okoliczności emisjii źródeł inspiracioi z zoò̀yczących kazu ideowego, w którym na sposób erudycyiny mogły się nakładać i przenikać różne treści.

88 J. Bieniarzówna, J.M. Małecki, dz. cyt, s. 424-425 (autorzy wiażą z tym przywilejem wybicie przez miasto medalu ku czci króla w 1677 r.). Sam akt wydano drukiem (egzemplarz w Bibliotece Jagiellon19. K. Hoszowsi, dz.cyt, s. $113-114$

g. A. Przybos, M. Rozt, dz, o tym nie wspominają, poza tym nie są znane podobne przypadki nagradzania polityów przez polski parlament.

Przedstawione przesłanki służą jedynie weryfikacji arbitralnego stwierdzenia o związku medalu z władzami Krakowa. Wobec braku jednoznacznych dowodów, trzeba tę hipotezę traktować jako jedną z prawdopodobnych. Nie można przecież wykluczyć, że numizmat powstał z woli i za pieniądze samego biskupa krakowskiego. Mógł doskonale służyć jako prezent zarówno w kraju, jak i w stosunkach z zagranica. Andrzej Trzebicki, podobnie jak inni prominenci, posługiwał się darami dyplomatycznymi, czego potwierdzeniem jest zapis w inwentarzu skarbca medycejskiego we Florencji, dotyczący bursztynowego tryptyku z krucyfiksem, datowanego na $1677 \mathrm{r}$., opatrzonego herbami Innocentego XI oraz ordynariusza krakowskiego ${ }^{91}$.

Przechodząc do zagadnień związanych z ikonografią i programem ideowym omawianego medalu, należy stwierdzić oczywisty wydźwięk apologetyczny samej jego formy, wynikający z antycznej genezy (imago clipeata) i przypisywanych jej znaczeń, a także z praktyki honorowania w ten sposób przedstawicieli najwyższej elity świeckiej i duchownej. Medale portretowe powstały w okresie renesansu na wzór numizmatów antycznych. Szczególnie pilnie studiowano wówczas rzymskie monety z popiersiami cesarzy i obiegającymi je lezendami na awersie oraz przedstawieniami lub pojedynczymi przedmiotami o charakterze symbolicznym na rewersie ${ }^{92}$.

91 K. Hinrichs, Bernstein, das „Preußische Gold" in Kunst- und Naturalienkammern und Museen des Grades doctor philosophiae (Dr. Phil) Philosophischen Fakultät III der Humboldt-Universiät zur Berlin, 2006, s. 271.

$92 \mathrm{Na}$ ten temat bardzo obszerna literatura, tytułem przykkładu można przywołać: G.F. Chiai, Das Münzporträt in der Renaissance w: Vorträge zur Geldgeschichte 2012,
hrso von R. Walburg, Frankfurt am Main 2013, s. 5-39. 
Świetnym przykładem czerpania motywów z monet antycznych w nowożytnej produkcji emblematycznej jest dzieło węgierskiego humanisty Jánosa Zsámboky'eoo (Joannesa Sambucusa) Emblemata, et aliquot nummi antiqui operis, po raz pierwszy wydane

w Antwerpii w 1564 r., później wielokrotnie wznawiane (w tym po francusku oraz holendersku|93. W tej tradycji mieści się meda Andrzeja Trzebickiego.

Zanim jednak przejdziemy do odczytania znaczeń związanych z emblemem na rewersie, musimy się zatrzymać przy samym portrecie biskupa pierwszą kwestią jest wiarygodnóć rysów portretowantią jest wiarygodnoścý pón portreawanego. Aby ją zweryflkowac, powinnismy zestawić popiersie na numizmacie $z$ autentycznymi wizerunkami biskupa. Dysponujemy dzisiaj kilkoma dziełami malarskimi i rzeźbiarskimi, które powstały za życia Andrzeja

Trzebickiego, a także stosunkowo niedługo po jego śmierci. Najcenniejszym źródłem do poznania wyglądu krakowskiego hierarch jest jego oficjalny, reprezentacyiny portret jest jego ofcject repre skupów krakowskich wrużgankach klasztoru franciszkanów99

93 A. Visser, Joannes Sambucus and the learned image: the use of the emblem in late-Renaissance humanism,

french/books php?id=FSAb,

23 UI 20201. Zob. B. Czarski. Recepcja antycznej ikonografii monetarnej w XVI-wiecznych drukach emblematycznych (projekt badawczy Biblioteki Narodowej), ,Rocznik Biblioteki Narodowej" 2015, nr 46, s. 109-134.

94 Zabytki XVII wieku. Wystawa jubileuszowa Jana II

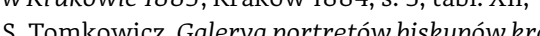
sich whrużgankach klasztoru OO. Francisskanów wKrakowie, Kraków 1905, s. 129-146; M. Giżyńska-Matecka,Portret biskupa Andrzeja Trzebickiego whruzzankach Klasztoru OO. Franciszkanow Wrakowie, ,Zeszyty Naukowe U.Prace z Historii A. Przyboś, M. Rożek, dz. cyt. s. 129-131. Ograniczo do popiersia kopia (zmodyfikowana, biskup bez infuły) zr. 1882, autorstwa Ludwika Łepkowskiego, w pałac biskupim w Krakowie. J. Skrabski, Portret Andrzeja (il. 6-7). Inne notowane w literaturze konerfekty (w Arcybractwie Miłosierdzia95 oraz w klasztorze cystersów w Mogile ${ }^{96}$, ie budza takiego zaufania co do wiernoś oddania cech fizjonomicznych. Z pewnością na uwage zasugue popierie kutew wiaym mar zar une popiersiekute w biakego ponnika nagrobnego ustawionego W 1696 r. W prezbiterium jezuickiego koscioła pw. św. św. Piotra i Pawła97 (il. 8-9). Według Michała Wardzyńskiego rzeźby figuralne i najważniejsze detale zdobnicze są dziełem Sulpiciusa Gode z Cambrai, znającego wenecką twórczość Flama nda Josta de Court a architektura oraz chrząstkowo-małżowinowa tablica zostały zrealizowane przez Jakuba Bielawskiego ${ }^{98}$

\section{https://sdm.upjp2.edu.pl/dziela//} 2ebickiego [dostęp 17 III 2020].

dz. Hoszowski, dz. cyt., s. 135; A. Przyboś, M. Rożek,

ś, M. Rożek, dz. cyt., s. 131

K. Hoszowskki, dz. cyt., s. 130-132; S. Załęski, O.O. Szkic historyczny Nowy Sacz 189w w Krakowie. I. Daranowska tukack Andrzeja Trzebickiego w kościele śś. Piotrai Paw w Krakowie, ,Biuletyn Historii Sztuki”, r. 39, 1977, s. 177-190; A. Przyboś, M. Rożek, dz. cyt, s. 125-126, il. 32; P. Krasny, Nagrobek biskupa Andrzeja Trzebic kiego w kosciele ss. Piotra i Pawta w Krakowie a plastyka nagrobna Domenica Guidi, w: Między
gotykiem a barokiem. Sztuka Krakowa XVI XVVII wieku. Materiały sesii naukowej zorganizowanej przez Oddziat Krakowski SHS, red. E. Fiałek, Kraków 1997, s. 101-112; M. Fabiański, O jezuickim nagrobku biskupa Andrzeja Trzebickiego, „Folia Historiae Artium”, Seri Nowa, t. 10, 2005, s. 127-160; tenze, Smierc izmysty Bartoli S.J. w: Italská renesance a baroko ve střední Evropè. Př́spěvky z mezinárodníkonference. Olomouc 17.-18. ríjna 2003, red. L. Daniel, Olomouc 2005, s. 185-196; M. Wardzyński, Organizacja pracy ip od dugie twanie" for mo poczel hu XVW wiek i wczesnobarokowych, w: Studia nad sztuka renesansti ibaroku, t. 11: Tradycja i innowacja w sztuce nowożytnej, red. I. Rolska, K. Gombin, Lublin 2012, s. 344, il. 14. 98 M. Wardzynski, Organizacja pracy..., dz. cyt., s. 344 il. 14; tenże, Marmur i alabaster w rzeźbie i małej

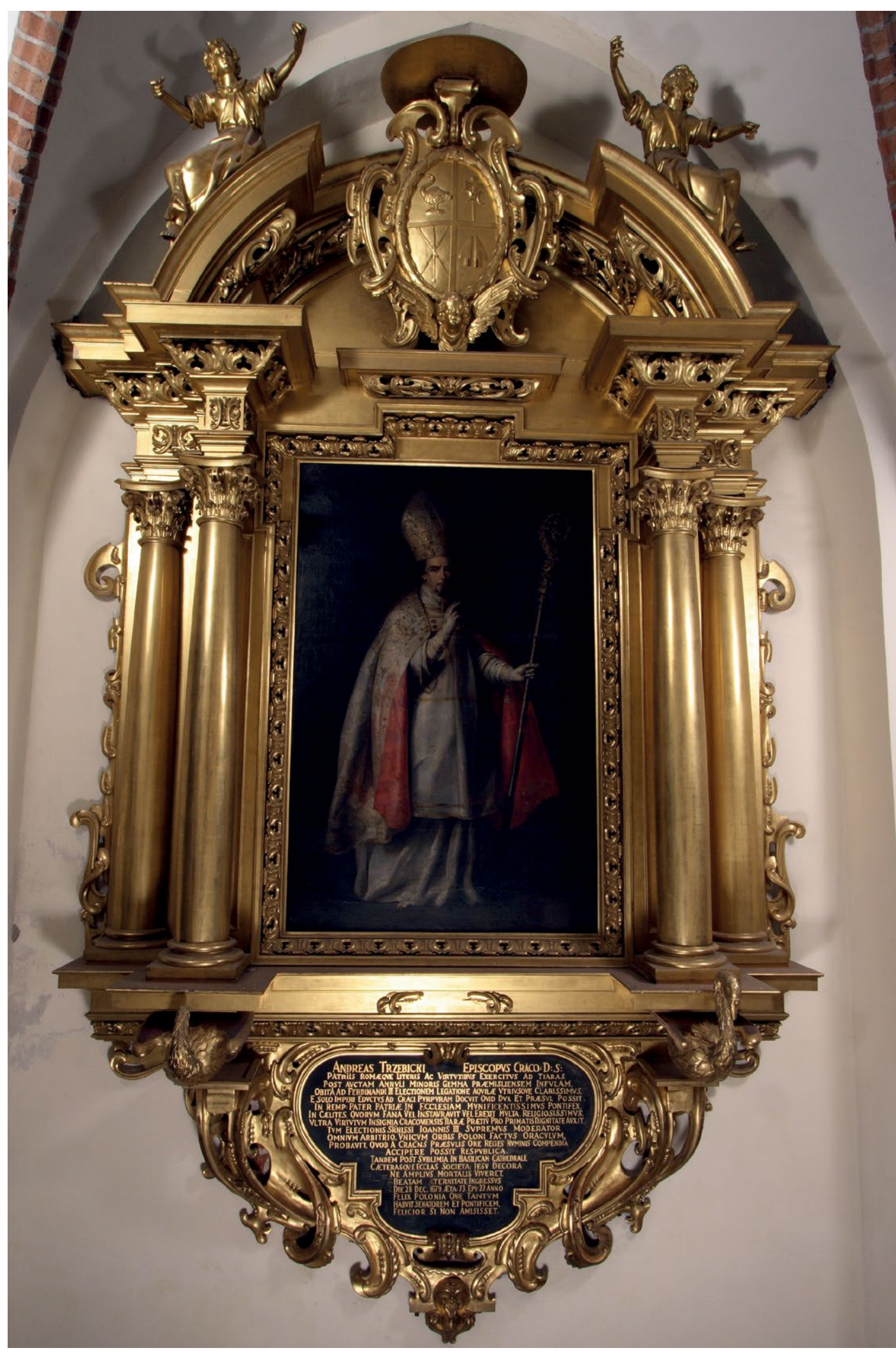

6. Daniel Schultz, Portret biskupa Andrzeja Trzebickiego,
ok. 1679 r., klasztor franciszkanów w Krakowie. Fot. S. Micht 
7. Daniel Schultz, Portret biskupa Andrzeja Trzebick

franciszkanów w Krakowie. Fot. S. Michta

Wcześniej, bo w 1683 r., powstała klęczacca statua biskupa wykonana ze złoconego mosiądzu, stano ny element pomnika w ka sta unzzonego pier wotnie naprzeciw oltarza Pana jezusa Ukrzyżowanego, a obecnie w nawie północnej99 (il. 10). Oba monumenty ufundowa siostrzeniec Andrzeja Trzebickiego, Kacpe Cieński ${ }^{100}$. W 1699 r. uzyskał zgodę miejscowej kapituły na umieszczenie kolejnego symbolicznego nagrobka z podobizną swego krewnego w kolegiacie w Sandomierzu, brak jednak potwierdzenia realizacji tego zamiaru ${ }^{101}$. Niewątpliwie zależało

Cieńskiemu na realizmie wyobrażeń poCleńlo mnikowych Andrzeja Trzebickiego, na co wskazuje pełna ich zgodnośc z fizjonomią ukazaną na płótnie Daniela Schultza. Z cał pewnością fundator musiał wskazać albo dostarczyć wykonawcom odpowiedni wzór do naśladowania.

Podobnie musiało być w przypadku omawianego medalu, zawierającego wizerunek, mimo miniaturowych rozmiarów, znakomicie oddajacy twarz znaną ze wspomnianego portretu biskupa u krakowskich

\section{-materiałoznawcze przemian tradycii artystycznych} od XVI do poczatku XVIII wieku, Warszawa 2015, s. 289, 569, il. 849-850.

99 K. Hoszowski, dz. cyt., s. 127-130; Katalog zabytków sztuki w Polsce, t. 4: Miasto Kraków, cz. 1: Wawel, red. J. Szablowski, Kraków 1965, s. 72, il. 673; M. Rożek, Katedra wawelska wXVIT wieku, Krakow 1980, s. 104, 107-108, 123-126, 135, 143, 11. 19, 24, 27-28, A. Przybo Marmur i alabaster..., dz. cyt., s. 272, 295, 568, il. 849 . 100 Kacper Cieński był synem Wojciecha oraz Jadwigi gnieźnieńskim, od 1665 - krakowskim, a w r. 1679 został dziekanem kapituły krakowskiej, administrator diecezji krakowskiej podczas sediswakancji wr.1699/700; pochowany w kosciele pw. św. šsw. ikanoników sandomierskich od 1186-1926r. tudzież sesje kapituły sandomierskiej od 1581 do 1866 r. Radom 1926, s. 42; B.S. Kumor, Dzieje diecez)i krakowskiej do roku 1795, t. 1, Krakow 1998

1011. Wiśniewski, dz cyt, s. 42,120

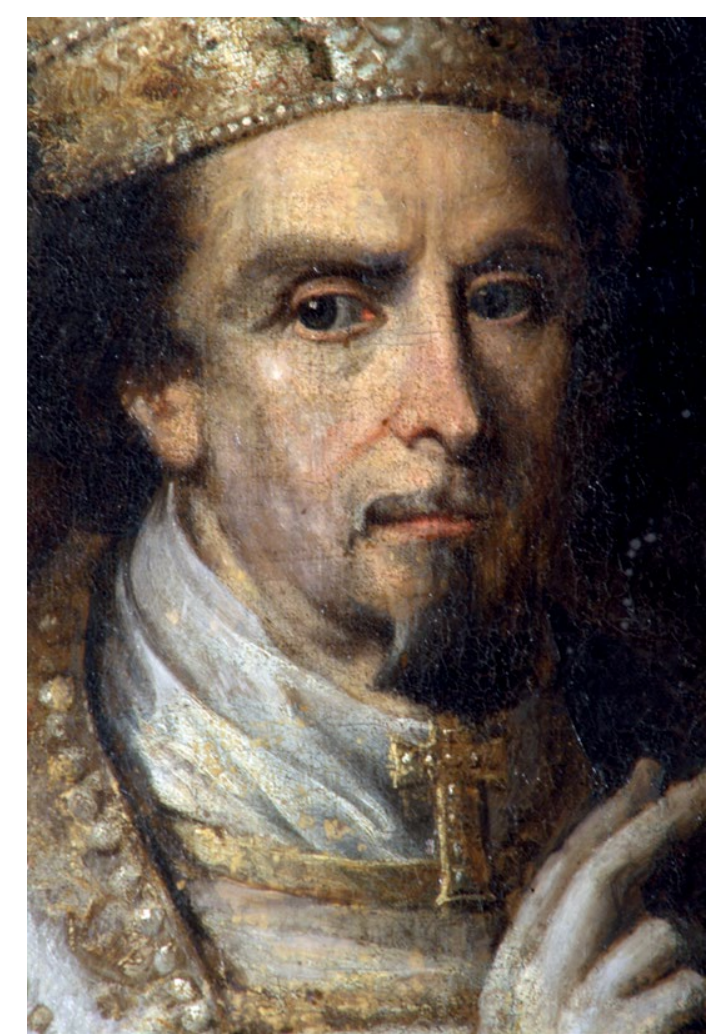

franciszkanów: szczupłą, z lekko zapadniętymi policzkami i wydatnymi kośćmi policzkowymi, z wąską bródką.

Proces wytworzenia medalu miał

charakter bardziej złożony, niż to się zwykło przedstawiać, przypisując medalierowi wszystkie jego fazy. Tymczasem, jak to wykazał na konkretnych przykładach Jacek Tylicki, pracowało przy takim miniaturowym dziele kilku artystów. W Gdańsku z wybitnymi twórcami numizmatów współdziałali miejscowi malarze, dostarczający projektów także do wyobrażeń portretowych. Z Samuelem Ammonem wsṕttretowych. Z Samulem Aspót pracow i Adof Boyz Johannem Hohnem St. oraz jego synem ${ }^{103}$. W związku z potwierdzonym autorstwem krakowskiego portretu Andrzeja Trzebickiego z r. 1664, szczególnie interesujące jest zaangażowanie Daniela Schultza w realizację numizmatów, co

102 J. Tylicki, O historii sztuki i numizmatyce, czyli kto projektował niektóre donatywy gdańskie Zygmun-
ta III, „Biuletyn Numizmatyczny” 2009, nr 1, s. 27-38. 03 Tenże, O gdańskiej historii sztuki i numizmatyce raz jeszze, O gdanskiej historii sztuki i numizma so

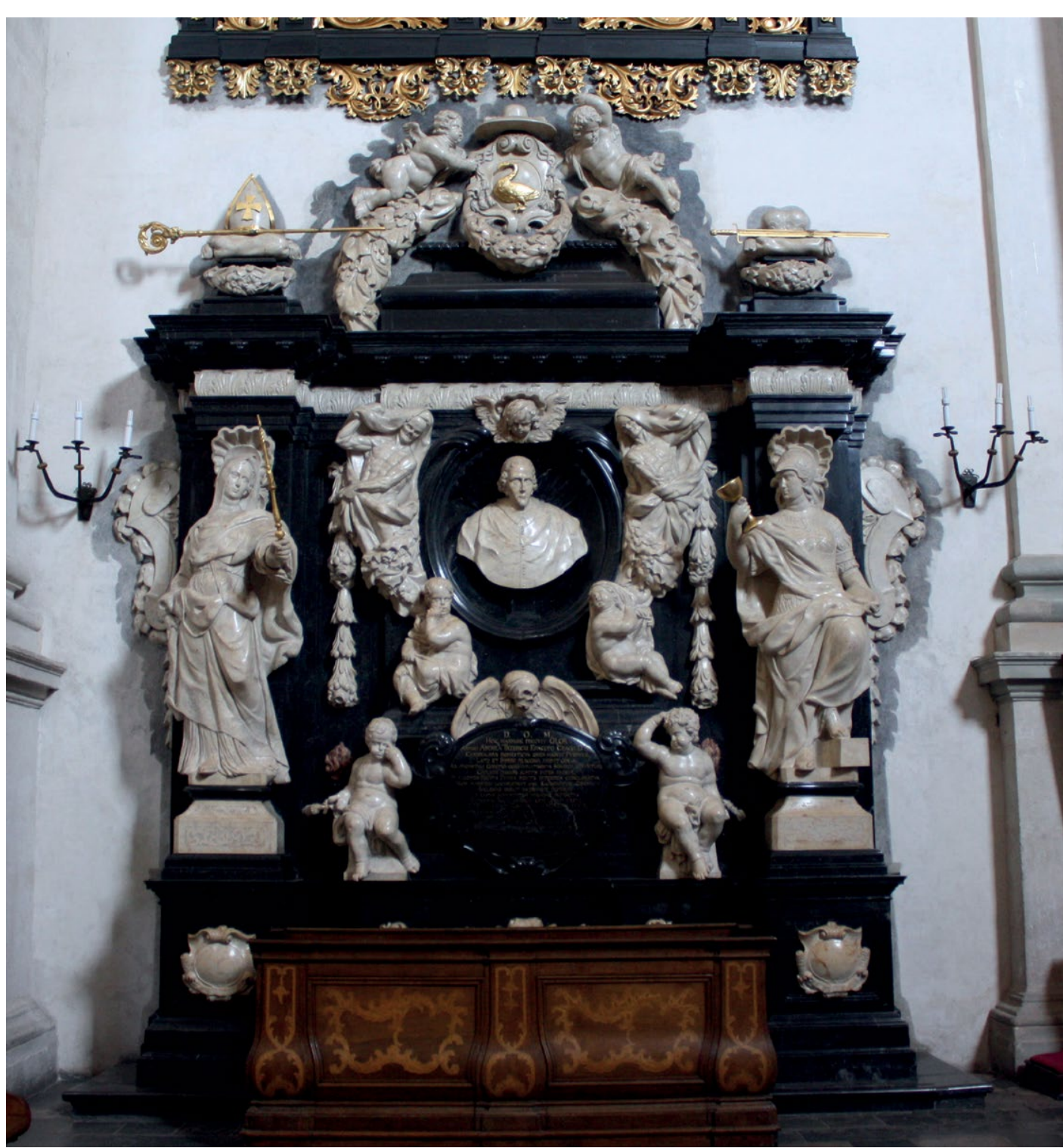

8. Jakub Bielawski, Sulpicius Gode, Nagrobek biskupa Andrzeja Trzebickiego, 1696 r., kościół pw. św. św. Piotra i Pawła w Krakowie. Fot. M. Walczak

potwierdzają księgi kasowej kamlarii gdańskiej. Wiadomo, że malarzowi zapłacono wr. 1650 za dwa portrety jako wzór dla rytownika stempli. Jacek Tylicki identyfikuje je $z$ wizerunkami Jana Kazimierza ${ }^{104}$. Kto i na jakiej podstawie przygotował projekt wykorzystany przez Johanna Höhna St. do rytowania stempla medalu Trzebickiego, tego na obecnym etapie badań nie da się stwierdzić. Autorem wizerunku mógł być sam medalier, który pozyskał wiarygodny

$\overline{104 \text { Tamże, s. 171-173. }}$ portret biskupa, mógł być nim także gdańszczanin Daniel Schultz. Jeśli medal Trzebickiego został zamówiony przez rade miejską Krakowa, można brać także pod uwagę znanego krakowskiego malarza Jan Trycjusza, u którego rajcy zamówili w r. 1676 konterfekt Jana III Sobieskiego do Sali Pańskiej ratusza ${ }^{105}$.

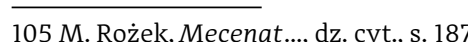




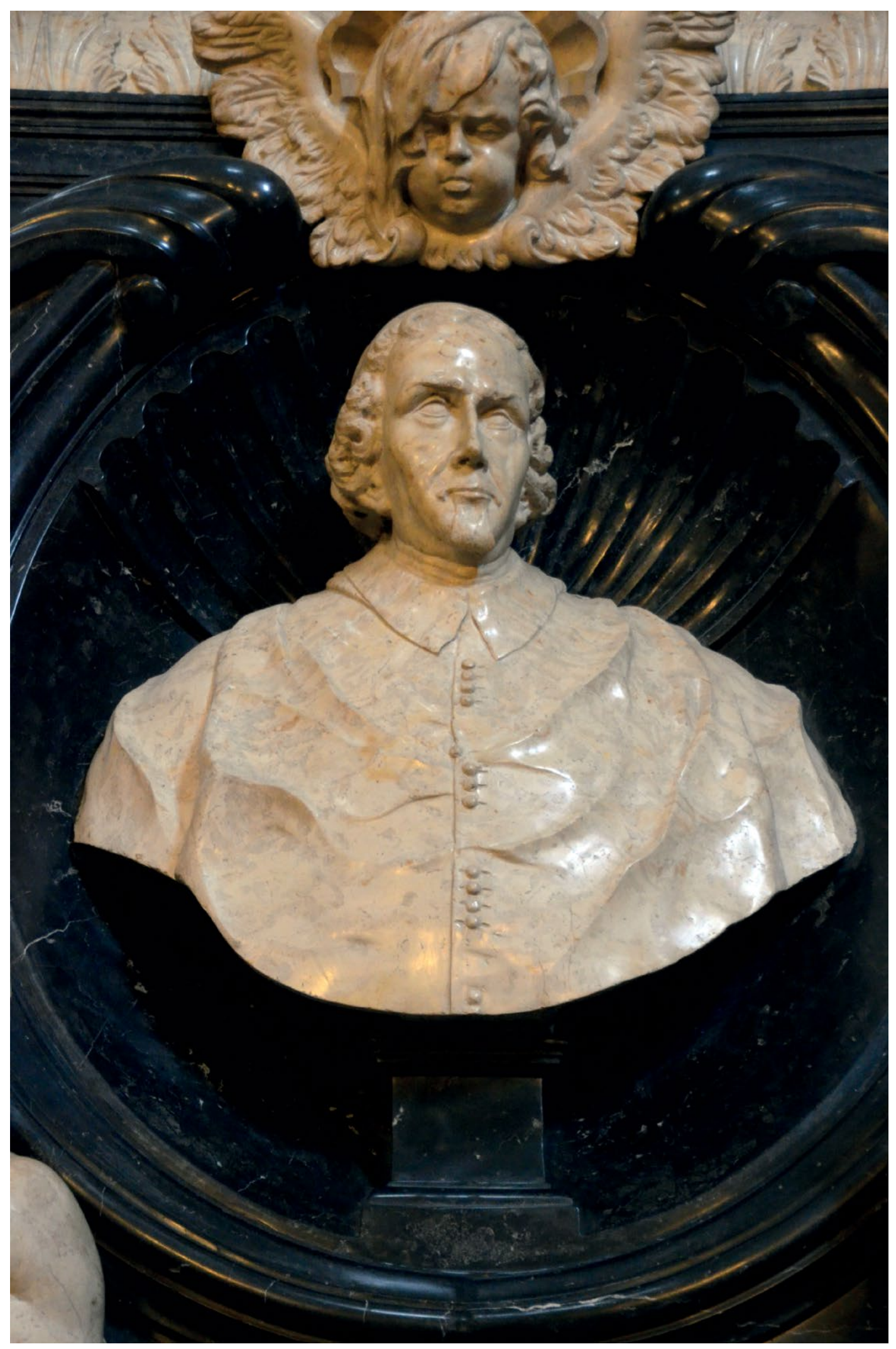

9. Sulpicius Gode, Popiersie biskupa Andrzeja Trzebickiego z jego

nagrobka, 1696
Fot. M. Walczak

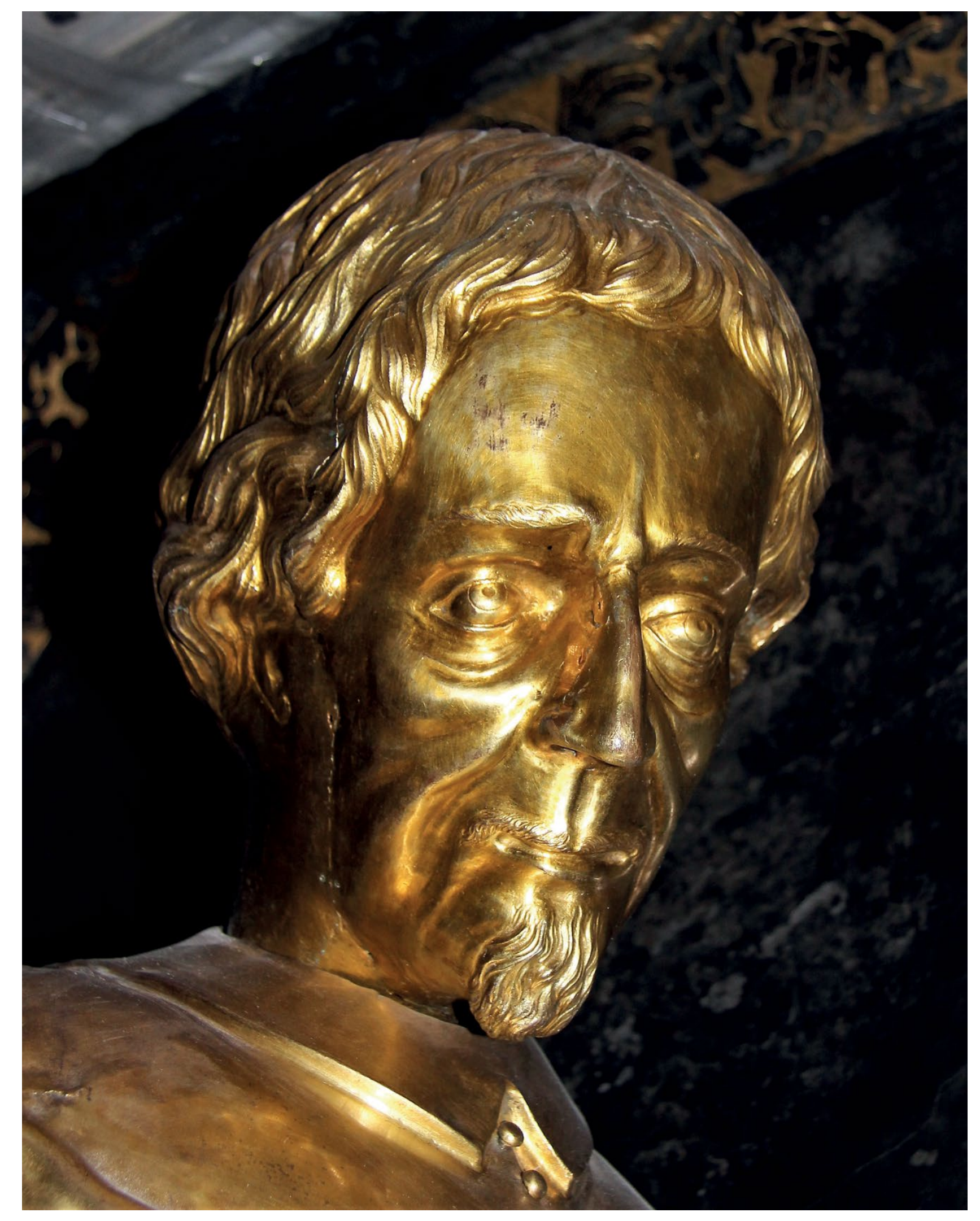

10. Pomnik biskupa Andrzeja Trzebickiego, fragment, 1683 r 


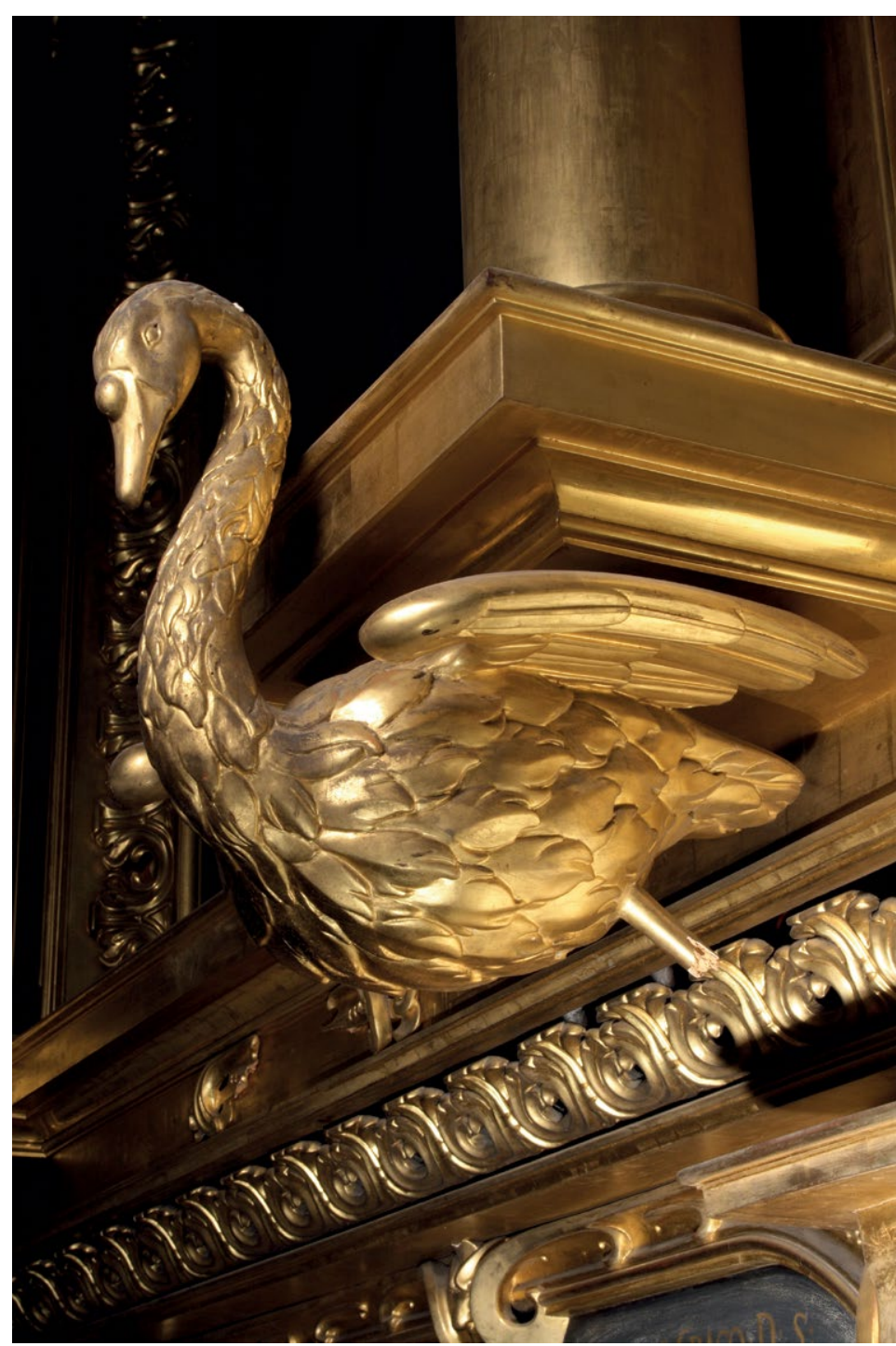

Na bliższe rozpoznanie zasługują przesłania zawarte w numizmacie. Jeśl chodzi o kompozycję awersu, to należy stwierdzić, że realizuje ona rozwiązanie najbardziej rozpowszechnione w epoce nowożytnej: zopiersiowym portretem noczonym legendą. Jednocześnie, ze względu na przynależno tycańs tycznie skojarzenie z numizmatami ho rującymi papieży i wyższą hierarchię Kościoła rzymskiego. W przypadku ujęcia ograniczonego do głowy i ramion, zróżnicowanie ikonograficzne i znaczeniowe dokonywane było przez wybór odpowiedniego ubioru duchownego. Widać to doskonale na przykładzie papieży, prezentowanych w różnych odmianach stroju
11. Fragment obramienia portretu biskupa Andrzeja Trzebickiego, ok. 1679 r., klaszto franciszkanów w Krakowie. Fot. S. Michta

pontyfikalnego: w uroczystej kapie (z haftowanymi postaciami apostołów, świętych, Piotrowi), w moceie istule, w tiarze lub w camauro na głowie. Każdemu z tych ujęć przypisać można różne intencje i komunikaty skierowane do odbiorcy. W przypadku świeckich władców pojawiają się stroj współczesne lub kostiumy all'antica, cywilne lub wojskowe itd. Mocet kryjący ramiona Andrzeja Trzebickiego jest znakiem zwierzchności nad Kościołem lokalnym i dlatego prawo jego używania przez biskupów ograniczone było tylko do terytorium własnej diecezji.

Medal Trzebickiego reprezentuje powszechną w epoce nowożytnej praktyke wykorzystywania motywów heraldycznych do rozwijania, w oparciu o mniej lub bardziej oryginalny koncept, utworów apologetycznych, gloryfikujących wybraną osobistość. Budowa najbardziej nawet karkołomnych skojarzeń z postaciami, wydarzeniami, pojeciami, zaczerpniętymi z historii, Biblii, teologit, fllozofiliçy storil, Bibii, teologi, flozofi, była istotnym elementem pozjn iprozy, w tym szcze nie kazań. W kręgu biskupa Andrzeja Trzebickiego powstało oprócz omawianego medalu także kilka innych dzieł, eksploatujących motyw herbowego łabędzia. Niestety, nie zachował się wspaniały hełm wieży Zegarowej katedry krakowskiej ozdobiony dwunastoma złoconymi heraldycznymi ptakami upamiętniającymi fundatora ${ }^{106}$ Łabędzie wystepują również w obramieniu portretu w krużgankach

106 S.J. Podgórski, Certamen votorum inter dioeceses, Cracoviae 1711, k. $K_{1 r}$ B Benedykt od św. Józefa (Zawadzki), Infula Cracoviensis gemmis suis distincta, Varsaviae 1686, s. 369: ", Cathedrali Basilica non solum amplissime ornata, / Sed etiam excitata Non ciconijs tantum esse locum, sed \& Oloribus" A. Grabowski, Krakówi iego okolice, Kraków 1844, s. 124, przyp. f; K. Hoszowski, dz. cyt., s. 298-299, przyp. 47; M. Rożek, Katedra..., dz. cyt., s. 44-45; klasztoru franciszkanów w Krakowie, w którym podtrzymują kolumny (il. 11). Mniej znany pozostaje zachowany na Wawelu czerwony aparat liturgiczny z tkaniny pokrytej deseniem sieciowym z poię labedziami (il. 12) Zestawięi gedzianirozetamio il 12). Zestawienie godel herbów tabęz Poraj nie zostało dotąd wyjaśnione. Takie tkaniny z herbami wkomponowanymi $w$ deseń wykonywano dla prominentnych osób na specjalne zamówienie ${ }^{108}$. Ze złotogłowiu weneckiego lub rzymskiego wykonano komplet pontyfikalny (ornat, para dalmatyk, kapa, antependium - obecnie

przerobione na makate), w tym przypadku przerovione by Łabędź, Osto w kartusze nakryte infułami ${ }^{109}$ (il. 13).

107 K. Hoszowski, dz. cyt., s. 154; Katalog zabytków... dz. cyt., s. 123 (tkanina ,o wzorze opartym na motywach w. XVI, wśród których rozety oraz
łabędzie (może godło herbowe), Polska (?), w. XVII) łabeddzie (może godło herbowe), Polska (?), w. XVII);
K.J. Czyżewski, Kapa pontyfikalna Piotra TylickiegoK.J. Czyżewski, Kapa pontyfikalna Piotra Tylick
konteksty, w: Tekstylia w zbiorach sakralnych. Warszawa 2013, s. 181, przyp. 45

108 Ostatnio o tkaninach herbowych: A. Bender, Wzorzyste włoskie tkaniny jedwabne z polskimi herbami w XVI XVII wieku, w: „Pod niebem Pótnocy". Z dziejów polsko-włoskich zwiazków artystycznych, red. P. Kondraciuk, Zamosc 2010, ss. nll., M. Piw dz. cyt.., s. 152-162; ze szczególnym uwzglednien skarbca katedry krakowskiej: K.J. Czyżewski, Kapa pontyfikalna..., dz. cyt., s. 179-182; tenże, Wawelska kapa biskupa Piotra Tylickiego w Piotrawinie - reka tulacja, w:Zespor zabylkowy Hotrawina - promocja naukowe poświecconej podsumowaniu badań

archeologicznych i prac remontowo-konserwatorskich w zespole sakralnym w Piotrawinie prowadzonych w latach 2011-2013 oraz wybranym zabytkom zgromadzonym na wystawie przy kosciele parafal20 109 K. Hoszowski, dz. cyt., s. 153-154; T. Mańkowski, 1954, s. 30-31, tabl. VI, il. 29: Katalog zabytków... dz. cyt., s. 122, 129, il. 821; M. Giżyńska-Matecka dz. cyt., s. 52, przyp. 46; A. Bender, dz. cyt., s. nlb., il. 20-21; K.J. Czyżewski, Kapa pontyfikalna..., s. 181,

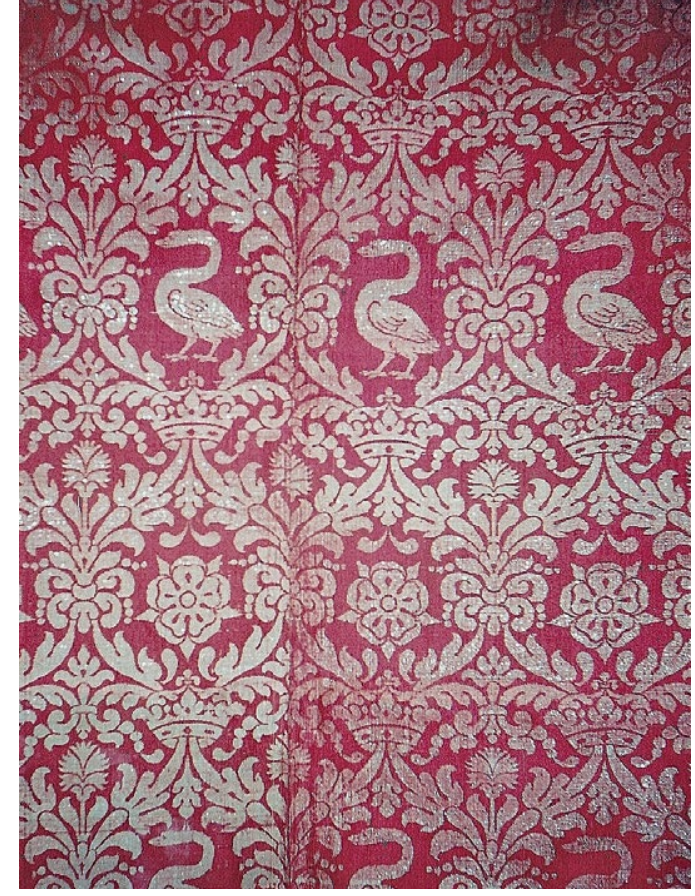
biskupa Andrzeja Trzebickiego, 3. ćw. XVII w, katedra na Wawelu. Fot. K.J. Czyżewski

Znaczącą rolę wyznaczono również herbowi Łabędź w niezwykłym nagrobku hiskupa w kościele św. św. Piotra i Pawła, w którym wieńczy on rozbudowaną kompozycję architektoniczno-rzeźbiarską ${ }^{110}$. Do niego też nawiązuje tekst łacińskiego epitafium mówiący o łabędziu, który zastyg w marmurze:

Hoc Marmore Dirigvit Olor Amisso Andrea Trzebicki Episcopo Craco(viensi) D(uce) S(everiensi) Cardinalibus domesticvs omen habvit purpurae"

W nagrobku katedralnym postać łabędzia, poza czteropolowym herbem, pojawia się w inskrypcji: „Involucra mentium exosus niveum pactus, lucidamque

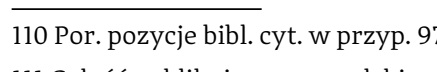

11 Całość publikuje wraz z polskim tłumaczeniem 


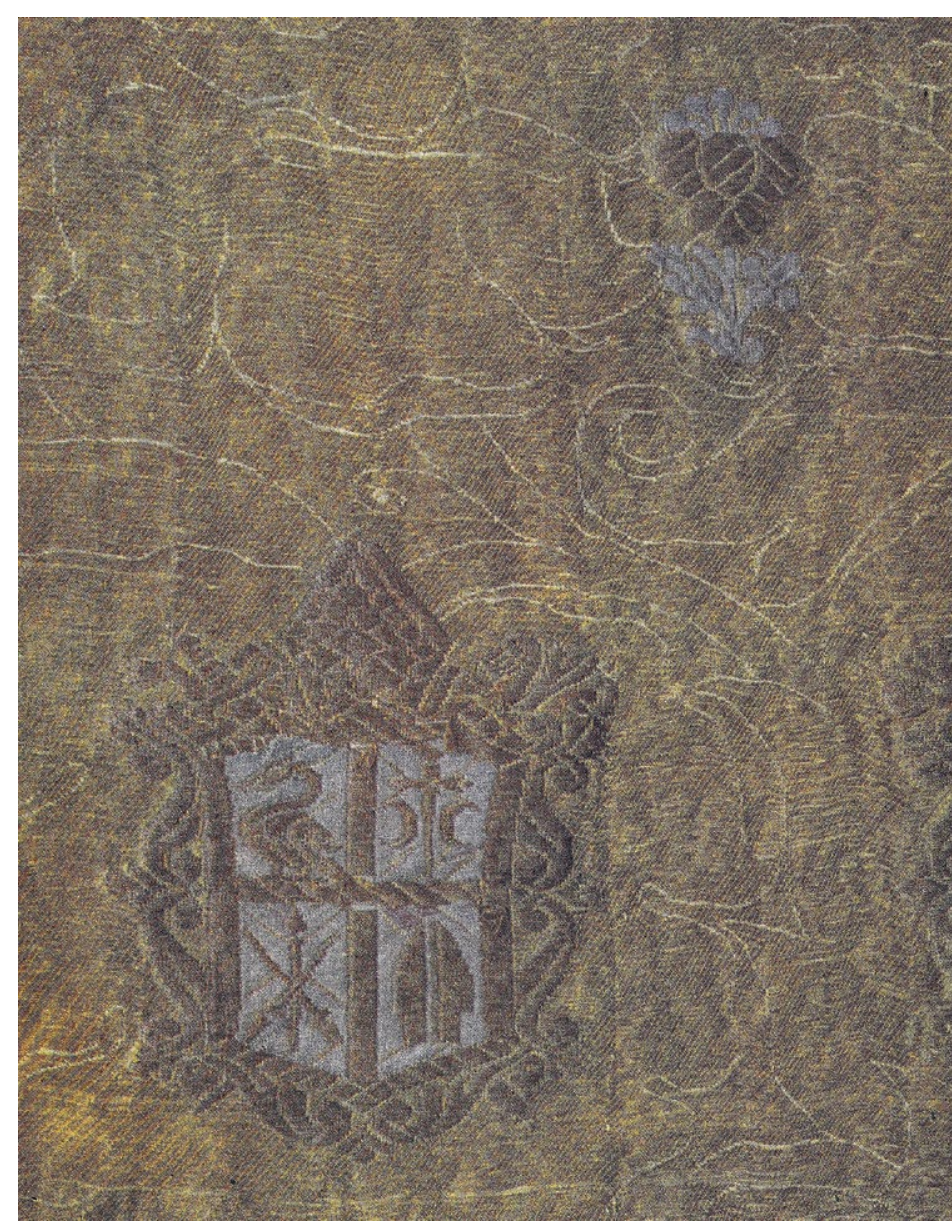

13. Fragment ornatu z herbem złożonym biskupa Andrzeja Trzebickiego, 3. ćw. XV
Fot. wg T. Mańkowskiego, dz. cyt.

interioris vitae crystallum gentili cygn suo concolorem unice adamavit" ${ }_{112}$, co Edward Raczyński przetłumaczył następująco: „brzydząc się pokryciem duszy umysł 位 kryształ z herbowym łabędziem jednofarbny umiłował"113.

Łabędź jest figurą często spotykaną zarówno w heraldyce ${ }^{114}$, jak i emblematyce ${ }^{11}$ Wykorzystanie figur heraldycznych w twórczości emblematycznej jest dobrze

112 Corpus Inscriptionum Poloniae, t. 8: Województwo krakowskie, z. 1: Katedra krakowska na Wawelu, wyd. i oprac. A. Perzanowska, Kraków 2002,

s. 212-213, poz. 204.

113 E. Raczyński, dz. cyt., t. 2, Berlin 1845, s. 376, przyp. b; K. Hoszowski, dz. cyt., s. 129-130.

14 B. Bei der Wieden, Mensch und Schwan, Bielefeld 2014, s. 189-195. znane i szeroko omówione ${ }^{116}$. Co do herbów biskupów krakowskich kwestie ich różnorodnego wykorzystania oraz inter symbolicznej poruszane byly sporadyczwyjątkowo wyrafinowanych konceptów heraldycznych współczesnych medalowi Trzebickiemu, są fundacje biskupa sufragana Mikołaja Oborskiego: monstrancja oraz para świeczników w katedrze krakowskiej, w których jako motyw o wielu znaczeniach pojawia się kolumnagodło herbu Roch"18.

$$
\text { Znaczące w kontekście medalu }
$$

z 1677 r. są wszelkie przypadki symbolicznego i remblematycznegowykorystania herbowego łabędzia dla uczczenia krakowskiego biskupa Najczęściej można spotkać

116 P. Buchwald-Pelcowa, Emblematyka w późnobarokowych drukach polskich, ,Biuletyn Historii Sztuki", r. 42, 1980, nr 3/4, s. 401-412; J. Pelc, Stowo i obraz na pograniczu literatury isztuk plastycznych, Kraków
2002 . Z opracowań szczegółowych na uwagę zastuguje m.in. A. Stankiewicz, Tréśi propagandowe herbu złozonego Jana Stanistawa Sapiehy z $1617 / 1620$ historii, red. J. Rogulski, Kraków 2013, s. 295-340.

17 P. Krasy i jej symbolika ,w dwojakim nawet sensie", wa Katedra krakowska w czasach nowożytnych (XVI-XVIII w.), Kraków 1999, s. 121-128; A. Betlej, Baranek (i iwy). Przykłady wykorzystania znaku herbowego w dekoradeach artystycznych wXVI wieku, w.Ex voto. Studia urodzin i $w$ 50. rocznice świecceń kapłańskich, red. P. Mrozowski, J. Żmudziński, Jasna Góra 2012, s. 503-509; B. Czarski, Stemmaty w staropolskich ksiazzkach, czyli rzecz o poezji heraldycznej, Warszawa Felicina Szaniawskiego): BM. Wotyniec, Ostoja uwaginad dziejami herbu wśredniowieczu i cza nowożytnych w:Žródła staropolskie.... dz. cyt., s. 245-294.

18 J. Czyżewski, Wystawił dwie kolumny, a na wierzchu kolumn robotę na ksztattlilyi położyt, w: Ex voto. Studia..., dz. cyt., s. 603-625. Z bpem Mikołajem Oborskim można zwiazzac jeszcze jedną monstran parafialnym w Wawrzeńczycach; iest ona dziełem bliźniaczym względem ostensorium katedralnego z r. 1686. J. Skrabski, Monstrancja, w: Rzemiosło Arty styczne Małopolski, https://ram.upjp2.edu.pl/dziela/

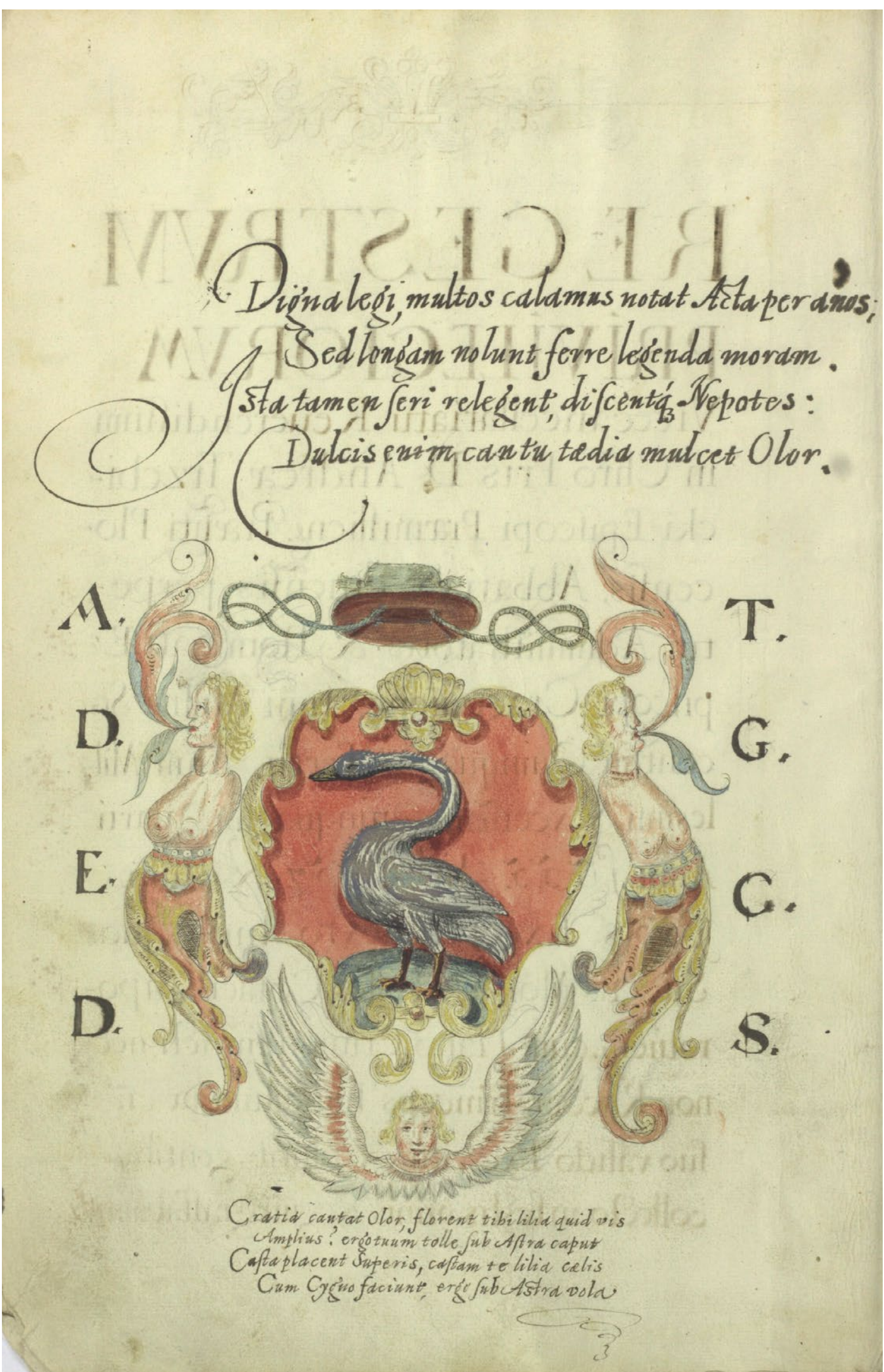

14. Akta podkanclerskie z lat 1653-1658, strona tytułowa z herbem biskupa Warszawa, Archiwum Główne Akt Dawnych,

sygn. 1401MK 196. Fot. AGAD 
kompozycje złożone z herbu i wierszowanego komentarza, określane mianem stemmatów ${ }^{119}$. Oczywiście, herb Łabędź pojawia się także w twórczości poświęconej różnym pieczętującym się nim osobom, czego przykładem może być utwór powstały w kręg Akademii Krakowskiej, autorstwa Stanisław Bieżanowskiego, Cygnvs academicvs [podkr. K.J. Cz., M. W.], inter suavissimum verbi incarnati concentum, ad aeternam felicitatem translatus, et ad feralem vrnam clarissimi olim et adm. Rńdi Domini, M. Mathiae Brvzynski ${ }^{20}$.

$$
\text { Szczególne miejsce w twórczości do }
$$

tyczącej Andrzeja Trzebickiego, zajmuje

kompozycja rozpoczynajaca rę

akta sporządzone

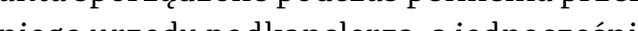

biskupa przemyskiego ${ }^{121}$. Chodzi o lawowa-

ny rysunek przedstawiający herb Łabęd

w rozbudowanym kartuszu pod kapelu-

szem biskupim, ktoremu towarzyszą dwa

epigramy (il. 14). Powyżej herbu:

Digna legi, multos calamus notat Acta per ann(n)os;

119 B. Czarski, Stemmaty..., dz. cyt.; tenże, Lemmata w staropolskich konstrukcjach stemmatycznych jako przejaw hybrydyzacii gatunkowej, „Terminus”, t. 14,

120 S. Bieżanowski, Cygnvs academicvs, inter suavissimum verbi incarnati concentum, ad aeternam

olim et adm. Rńdi Domini M Mathien Bryzynskissimi Coll: Maioris. S. Th. D. Decani S. Flor. Cancellarii Posnaniensis dignissimi. Lugubri elego [...] in palaestra Cynersciana advmbratus. Anno domini, 1646. Die 17. Decemb., Cracoviae 1646. Inne przykkady: S. Baczew-
ski. Panegiryk jako narzedzie komunikaci spoteczne"Charites Stowieńskie" Jana Zawickiego i, tabęé żałośnie śpiewajacy" Hiacynta Przetockiego, w: Panegiryk jako element życia literackiego doby staropolskieji oświeceniowej, red. M. SulejewiczNowicka, Z. Gruszka, wstęp M. Wichowa, Łódź 2013

21 AGAD, sygn. 1401 MK 196 (Regestrum privilegiorum 1653-1658 exceptos viticus, rebelles Cosaci Zaporovienses cum Hano Crimensi iuncti necnon Racocius princeps Transylvaniae cum suo valido exercitu ex pluribus gentibus
Sed longam nolunt ferre legenda moram. Ista tamen feri relegent, discentg(ue) Nepotes:

Dulcis enim cantu taedia mulcet Olor". Poniżej herbu:

Gratia cantat Olor, florens tibi lilia quid vis mplius? ergotuum tolle sub Astra caput asta placent Superis, castam te lilia caelis Cum Cygno faciunt, ergo sub Astra vola". Zwraca uwagę nawiązanie do legendarnego śpiewu ptaka i jego bieli, a także zestawienie jej z lilią. Te topiczne motywy wykorzystywano czesto w innych utworach ${ }^{122}$. Kompozycja rysunku kartusza ujejomość współczesnej publikacji Jana Jonstona, uznawanej za ostatnią humanistyczną systematykę zwierzą ${ }^{123}$ (il. 15). Anonimowy rysownik zdobiący akta podkanclerskie wykorzystał w uproszczeniu graficzną oprawę strony tytułowej szóstego tomu owego dzieła, poświęconego ptakom!'124 Najpewniej więc zapoznał się przy tej okazji z obszerną charakterystyką łabędzia, sporządzoną przez działającego w Lesznie uczonego $0^{125}$.

\section{K. Zachariasiewicz, Vitae episcoporum Premislien- sium ritus latini, Viennae 1844, s. 138, w 1744 r. poprzedził biogram Trzebickiego epigramem:
,Albaque collaudant quamvis sua lilia Galli / Hic imis jam superat lilia pulcher olor", w nawiz̨zani o Szymona Okolskiego, Orbis Polonus, t. 2 . \\ na herb biskupa. Thrax Aquilae grauis instat: OLO contra expedit alas,/ Hastamque Sui roboris arm Opem: / Et belli auspicium, \& neruum laturus in hostem, / Classica, non clangens ore, sed aere, sonat". A. Kanon, Lucubrationes oratoriae, Regum, Virorum, Panegyricis \& Elogii insignitae, Cracoviae 1676 , s. nlb. \\ 123 J. Czapla Miedzy autorem a drukarzem. Dobór ilustracij w „Historia naturalis" Jana Jonstona, "Zeszyty Naukowe Towarzystwa Doktorantów UJ. Nauki Społeczne" 2016, nr 14, s. 9-25. \\ $124 \mathrm{~J}$. Jonston, Historiae naturalis de avibus libri VI, rancofurti ad Moenum 1650 (drugie wyd. tamż \\ 125 Tami் s. 136-138.}

Stefan Damalewicz, dedykując biskupowi przemyskiemu Andrzejowi

Trzebickiemu wydanie konstytucji kanoników regularnych laterańskich, poprzedził swoje dzieło herbem Łabędź na kartuszu pod kapeluszem rangowym i opatrzył epigramem:

In Arma Gentilitia Illustrissimi

Reuerndissimi Domini. Ferre Aquilae dignus fulmina solus Olor.",

Sarmates ales ait, domus divina Tonantis, Quid, quod in alta, facit, sidera tollor? Echo, Olor.

Tunc mihi Diua Themis reples praecordia? Tunc mis

Me fore felicem tu quoque reris? Echo, Eris, Cuius at auspiciis Lechidae hoc sunt omine digni? Echo, Cygni.

Cygnus erit lenne leuamen. Echo, Amen. Cygne meos cantu haud frustra solate labores,

Pro Ioue, quae tulimus tela, tuere vigil ${ }^{\eta_{12}}$ Podobny charakter ma stemmat

umieszczony przez notariusza Tomasza Nykowskiego na odwrociu karty tytułowe sporząadzonego w r. 1676 na polecenie Andrzeja Trzebickiego rękopisu, zawierajacego statuty kapituły krakowskiej. Herbowi przydano wiersz:

„Diligit hic Patriam sinceri pectoris Ales, Praesulis est animo concolor ille sui. Candidus in Cygno nitor est in Praesule virtus,

Integritas, pietas, candida tota nitet.

Quid canet hic Cyonus, dulci per saecula

Quid cane

Optima Trzebicii Praesulis acta cant" Łąędź w tiarze (czytaj: mitrze bisk piej) pojawia się w tytule panegiryku pióra Jana Dziedzica z okazji wawelskiego ingresu w r. 1658: Olor Trebicianus pontificali pedo

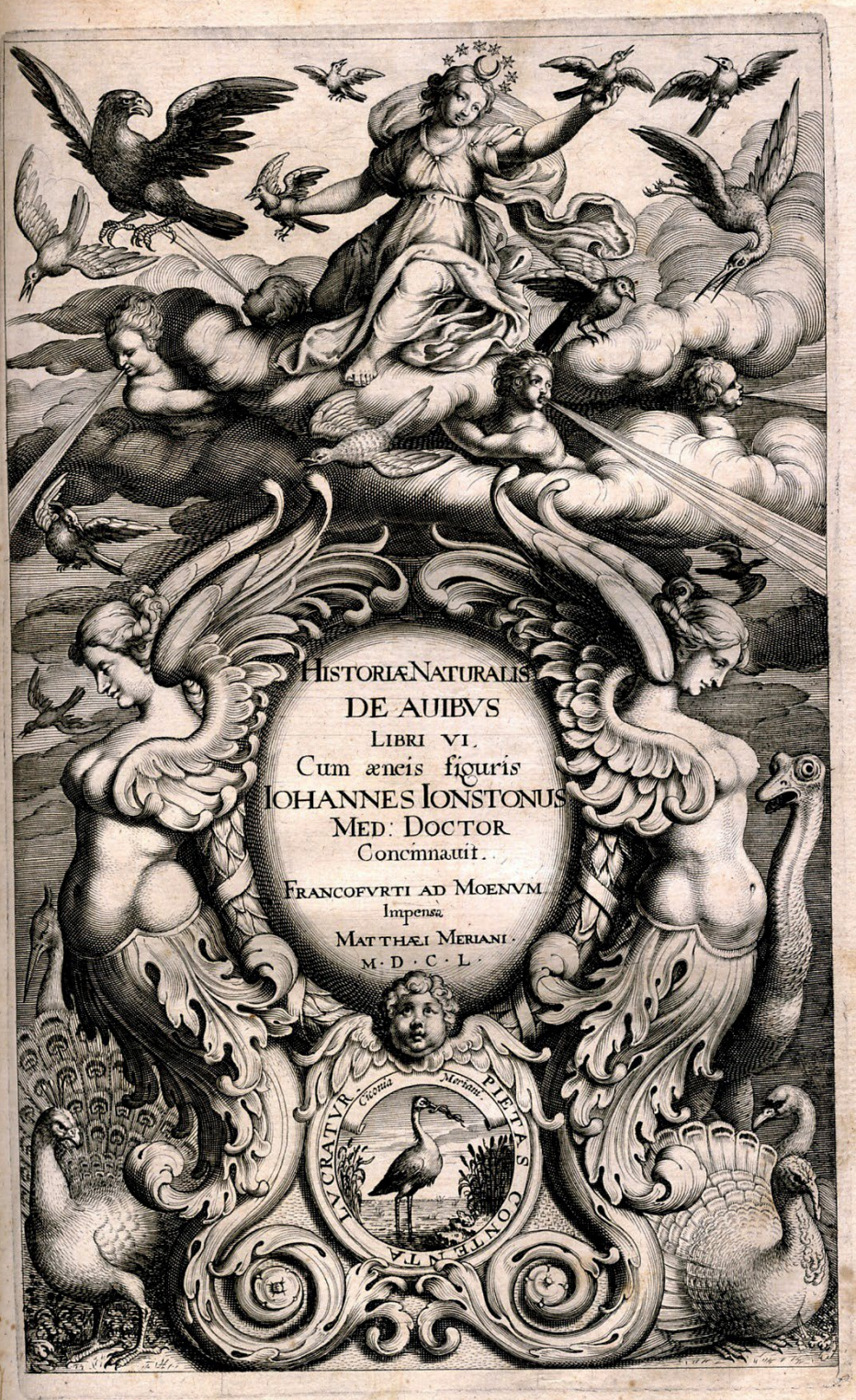

26 S. Damalewicz, Constitutiones Canonicorum Regularium Lateranensium Domus Calissien

27. K. Hoszowski Żywot., dz. cyt. s.115-116. 
tiara insignitus. Ad primum et auspicatissimum Illustrissimi et Reverendissimi Domin D. Andreae Trzebicki12.

Z tej samej okazji pochwałę nowego rządcy biskupstwa krakowskiego wydał również Jakub Rorajski, tytułując ją: Cygnus puri candoris nitor [podkr. - K.J. Cz., M. W. in Armis, Aula, Senatu, Ecclesia radios diffundens, Illustrissimo et Reuerendissimo Domin D. Andreae Trzebicki Episcopo Cracoviensi, Duci Severiae, Almae Academiae Cracoviensis Cancellario dignissimo ${ }^{129}$. Druk zawiera herb Trzebickich z wierszem łacińskim podpisanym przez Mikołaja Schedla.

Kolejny gratulant, Franciszek

Bernard Petrycy, także skorzystał z możliwości, jakie dawała figura heraldyczna nowego biskupa. W stemmacie umieścił wiersz zawierający oba łacińskie określeni łabędzia: „cygnus" $i$,olor"

"Hic, ubi Syderis infert sua culmina tectis, Istuleasque premit, rupe Vauellus aquas; Litibus adversis decertavere minisque Pro Cyono Princeps, Terra Polusque Tuo Iurgia certant $\&$ audit

Ut sua sint Terris, vota, Poloque sua, Caelica sydereus micet inter lumina Cygnus,

Sitque suus terris candidus, inquit, olor. Syderibus terram sic Praesul Maxime iungs; Sic Olor in gemino, Te Tuus orbe canit" ${ }_{130}$

Triedzic Olor Trebicianus pontificali pedo, tiar insignitus. Ad primum et auspicatissimum Illustrissin In Cathedralem Cracoviensis Ecclesiae Basilicam, ingressum ad iuga Vavellini Montis, dulces afflictae Ecclesiae et Patriae cantus modulans, Cracoviae 1658 129 J. Rorajski, Cygnus puri candoris nitor, in Armis, Aula Senatu, Ecclesia radios diffundens, Illustrissimo Episcopo Cracoviensi Duci Severiae Alme Academiae Cracoviensis Cancellario dignissimo in auspic ad Episcopatum Cracoviensem ingressu, debitae observantiae ac submissi cultus ergo; officiosissim

gestientis animi obsequio.... Cracoviae 165

30 F.B. Petrycy, Panegyricus illustrissimo ac reverendis
Na osobne omówienie zasługuje anonimowy druk wydany w Krakowie w imieniu jezuitów, również przy okazji ingresu biskupiego ${ }^{131}$. Wykracza on znacznie poza . Otóż stronę potytułową zajmuje rozbudowana kompozycja emblematyczna: łabęd na wysepce pośród wód, między dwoma wysokimi skałami; z jego dzioba wydobywa się fraza: „Fracta uocis Respondet imago”, skierowana do unoszącego się powyżej orła trzymającego w szponach infułę i pastorał. Poniżej widnieje elogia oparta na motywie kojarzonych ze św. Piotrem jako opoka i patronem kolegium krakowskiego:

"Qui modo Sanaeis niveus consederat undis, Nunc super Istuleas considet Ales aquas. At quocung(ue) locet felicem flumine nidum Hic Olor, argutum concinit ore melos Dulce melos Scopulis \& vallibus, eminus illi Resposat fracto saxea PETRA sono. Mireris, nostra sequimur si voce canentem? A PETRI resilit vocis imago PETRA". Do łabędzia nawiązał również Szymon Starowolski w drugim wydaniu żywotów biskupów krakowskich. Zawarty w nich długi wiersz na herb Trzebickiego zawiera taki passus:

"Quantas Trzebicki curas, bellique tumultus

Pertulit Andreas, in Patriae obsequiis; Candoris nivei, consummatique laboris Caystrius ales Olor, nobile Stemma, docet" ${ }^{132}$. Zbiór kazań Jacka Liberiusza (il 16) otwiera miedzioryt Dawida Tscherninga z herbem Andrzeja Trzebickiego trzymanym przez parę aniołków i dwuwierszem

\section{cathedram suam III nonas Novembris Anno D.M.
DC.LVIII ingredienti, Cracoviae [1658], s. nlb. 131 Echo Concentus ad Petram refracti seu Panegyricus Gratulatio, Cracoviae 165} 132 S. Starowolski, Vitae antistitum Cracoviensium
16. Gospodarz Nieba y Ziemi Iesvs Chrystvs Syn Bozy Bog Wcielony, Zbawiciel y Naprawca Swiata Pobożnemu Audytorowi na Kazaniach Wystawiony od X. Iacka Liebrivsza..., Kraków

„Illaesus candor cygni est, non diffluit vndis Illaesa et nostri Praesulis integritas ${ }^{{ }_{133}}$.

Nie zabrakło odniesień do łabędzia

w tekście dedykacji: „Szedłeś W.X.M. z młodych lat swoich wysokimi zawsze ku doskonałości cnot stopniami prowadząc wiek w sławie wonney, w boiaźni Bożey, w przedziwney obyczaiow skromności, w pilney około siebie straży. Iako pływaiącego po łłębokich wodach LABECIA, nie zalewa żadne by natęższemi wiatry poruszone fale. Natat vt vitreis CYGNVS nec mergitur vndis tak serca y statku W.X.M. żadne tego do przystaie, y czesto niemi dowcip, cnote, integritatem zalewa, nigdy nie ruszyły, an dosięgły".

W 1666 r. Szymon Stanisław

Makowski wydał zbiór kazań, które ofiarował "Illustrissimo et Reverendissimo Domino D. Andreae Trzebicki, Dei Apostolicae Sedis Gratia Episcopo Cracoviensi, Duci Severiae, regni Poloniae Senatori prudentissimo, Academiae Iagelloniae Cancellario dignissmo. Divino forsan afflatus Spiritu non nemo Principum, in suis Numismatibus Olorem Capite coroin suis Numismatibus Olorem Capite coro-

natum posuerat, cum inscriptione
invictus virtute divina: Tuae hoc

Illustrissime \& Reverendissime Princeps virtuti debetur elogium, qui Olore, pedo \& Tiar Pontificali, mitra \& gladio Ducali coronato insignitus, nihil quod ad Ecclesiae Sanctae commoda pertinet, praetermittis" ${ }_{134}$

W kolejnym dziele o charakterze dewocyjnym, dedykowanym Andrzejowi Trzebickiemu tym razem przez Jana Papczyńskiego ${ }^{135}$, na stronie potytułowej

133 J. Liberiusz, Gospodarz nieba y ziemie Iesus Christus Syn Boży Bog
Kraków 1665.

134 S.S. Makowski, Pars hyemalis concionum pro festivitatibus Christi, B. Virginis et sanctorum a prim

Januartiusque

135 J. Papczyń́ski, Orator Crucifixus sive ultima Septem

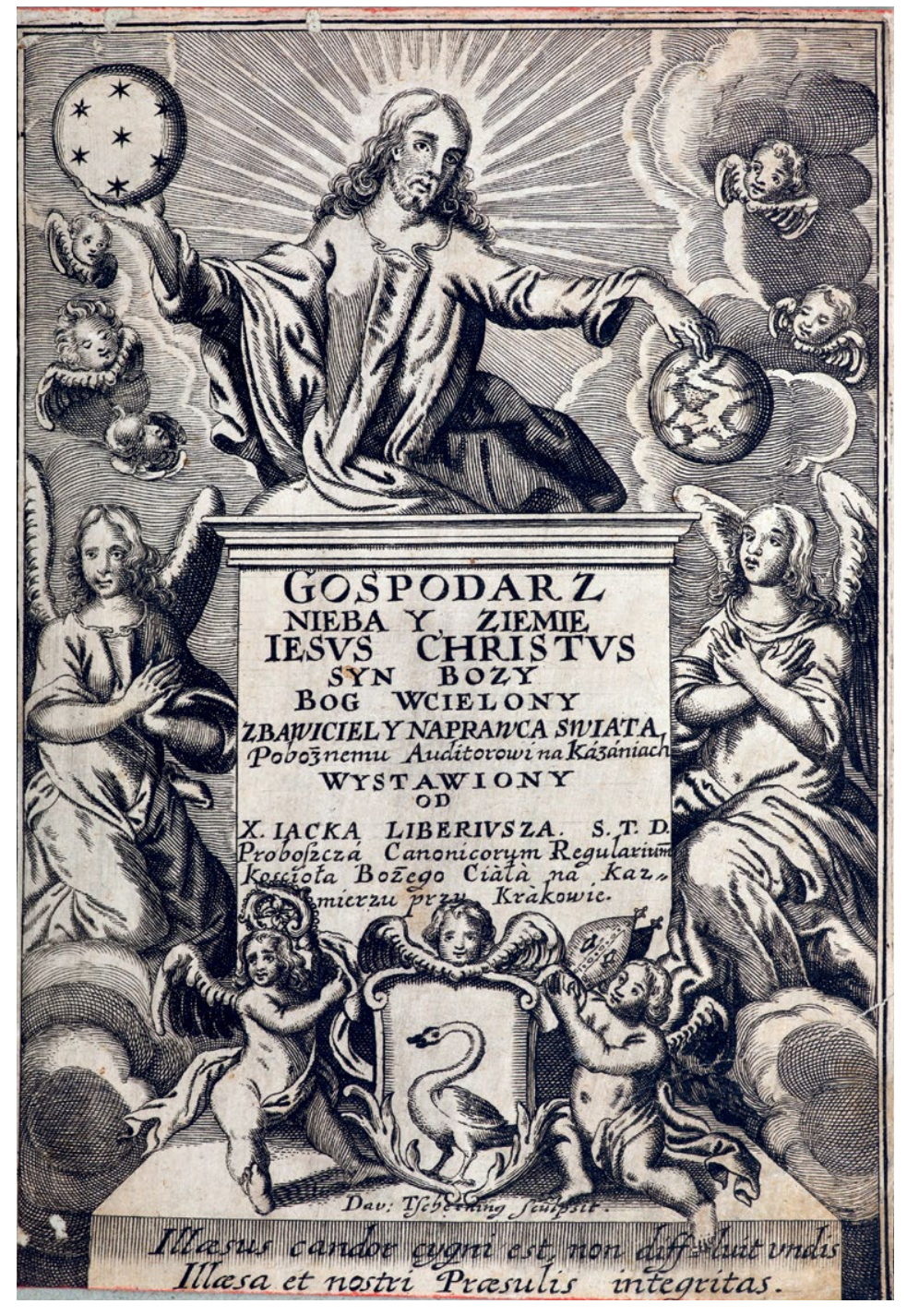

zamieszczono trzymany przez parę aniotow herb Łabędź ze stosownym epigramem: „Candorem Niueus Color hic designat OLORIS; Vox suauis suauem Moribus esse docet. Illaesus candor, vita est illaesa, fatemur: Atque; iuuat toties dicere: VIVAT OLOR".

Lektura dedykacji prowadzi do odkrycia bardzo szczególnego i twórczego wykorzystania przez autora biskupiej figury heraldycznej. Otóż Papczyński samego Chrystusa porównuje do białego łabędzia rozpiętego na krzyżu i zabarwionego purpurową krwią: „Niveus ille Coelestis OLOR expansus in ligno fatali, \& ante fata suavissime praecinens, nativum colorem in purpureum ex sangvinis profusione mutatus, non nisi Purpurato PRINCIPI consecrandus erat”, a następnie w konkluzji: „Suscipe 
igitur animo, quo polles, Heroico,

Celsissime ac Reverendissime PRINCEPS,

Cygnea haec expirantis in CRVCE vitae no-

strum omnium ac salutis AVTHORIS

Modulamina, \& me sub vmbra Alarum gen-

tilitij TVI CYGNI perpetuo velis conserva-

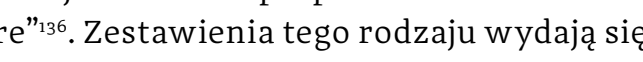

z dzisiejszej perspektywy odważne, nawet

niestosowne, ale w nowozy tnej literaturz panegiryczne utożsamienie wychwala-

nych osobistości z postaciami biblijnymi,

świętymi, a nawet osobami boskimi, było stałą praktyką.

Nie tylko w rękopisach i drukach znajdujemy stemmaty ku czci Andrzeja

Trzebickiego. W marmurze wykuto tablice

pamiątkową z r. 1670, wmurowaną w ścian

ufundowanego przez biskupa kolegium je-

zuitów przy kościele pw. św. św. Piotra

Pawła w Krakowie (il. 17). Herb fundatora

dopełnia wierszowana inskrypcja:

„Non opus est placido morti praeludare cantu:

Vivet in his saris Trebicianus Olor ${ }^{{ }_{137}}$.

$$
\text { Znaczna liczba utworów gloryfikują- }
$$

cych i upamiętniających krakowskiego bi-

skupa powstała z okazji jego śmierci.

W nich także znaczące miejsce zajmuje fi-

gura zaczerpnięta z herbu zmarłego.

Wojciech Waśniowski w Śmierci wielkiego

xiążęcia pisał: „Widział herbownego Łabęcia

Prześwietney Ich MMciów Panów

Trzebickich familiey, w Jaśnie Oświeconym

S. Pamięci Jego Mości X. Jędrzeiu

Trzebickim; a bacząc że y Liliowym świąto-

bliwego życia car

136 Tamże, s. nlb.

137 S. Załeski, Jezuici w Polsce, t. 4, cz. 2, Kraków 1905 s. 777 (w thumaczeniu: ,Nie ma potrzeby słodkich wywodzić przed skonem śpiewów / Zyć będzie w tych głazach Łabędź Trzebickich"); K. Hoszowski, dz. cyt., s. 94-97. Podobna tablica upamiętniająca dawniej na ścianie szpitala Św. Ducha, ale tym razen w tekście nie nawiazzano w żaden sposób do herbowego łabędzia. S. Tomkowicz, Zabytki budownictwa m. Krakowa. I. Szpital S. Ducha, Kraków
Bono publico słynie darami, przez różne honorów stopnie tak wyniosł in altum te w Senacie wtóre osiadł Krzesło" ${ }^{138}$.

Wielokrotne nawiązania do łabędzia, misternie wplecione w poetyckie frazy, znalazły się w jezuickim panegiryku wydanym okazji rocznicy śmierci dobrodzieja zako$n^{139}$. W żałobnych okolicznościach szczegolnie atrakcyjny wydawat się topos ostatniego, śmiertelnego łabędziego śpiewu $u^{140}$. Odnajdujemy go także w znacznie późniejszym utworze Jakuba Pawła Radlińskiego, który wykorzystał go dla podkré́lenia za-

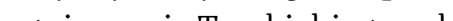
angazowania Trebickiego w kut Matki bostit powodowanej wiekien. Jego pielgrzymka na Jasną Górę, którą odbył w obliczu nadchodzącej śmierci, w podeszłym wieku, otrzymała poetycki komentarz:

„Praedictus Praesul complebat munera Cygni. Quo enim cygnus moribundus cantat amoene,

Depromitque suo, gutture dulce melos: Sic Paraesul quando sperabat proxima fata, Ad Divam supplex pergit, aditque frequens: Ut laudes ejus decantet ad instar oloris, t penetret terras cantibus, atque Polos" ${ }^{\prime 14}$ Źródeł wykorzystywanych przez

38 W. Waśniowski, Śmierć wielkiego xiqż̇ęcia pogrzebowym obzatowana kazanlem przy wyprowadzeniu grobu ciała [...]x. Iedrzeia Trzebickiego, biskupa 29 miesiaca stycrnia Roku Pańshiego 1680, Kraków [1680], s. 20.

139 Annua doloris sacra ilustrissimo ac reverendissimo d. Andreae Trzebicki, episcopo Cracoviensi duci Severiae, a Collegio Cracov: Societatis Jesu, fundator suo munificentissimo parentali carmine persoluta,

(a)

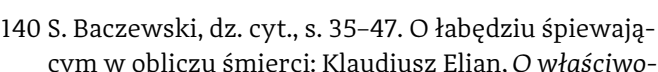

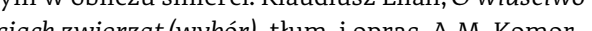
nicka, Warszawa 2003, s. 55, 112-113, 132, 200.

141 J.P. Radliński, Imago thaumaturga beatissimae virginis Mariae immaculate conceptae primo Hierosolymitana secundo Constantinopolitana tertio Belzensis quarto Claro-Montana Czestochoviensis, Cracoviae 1756,
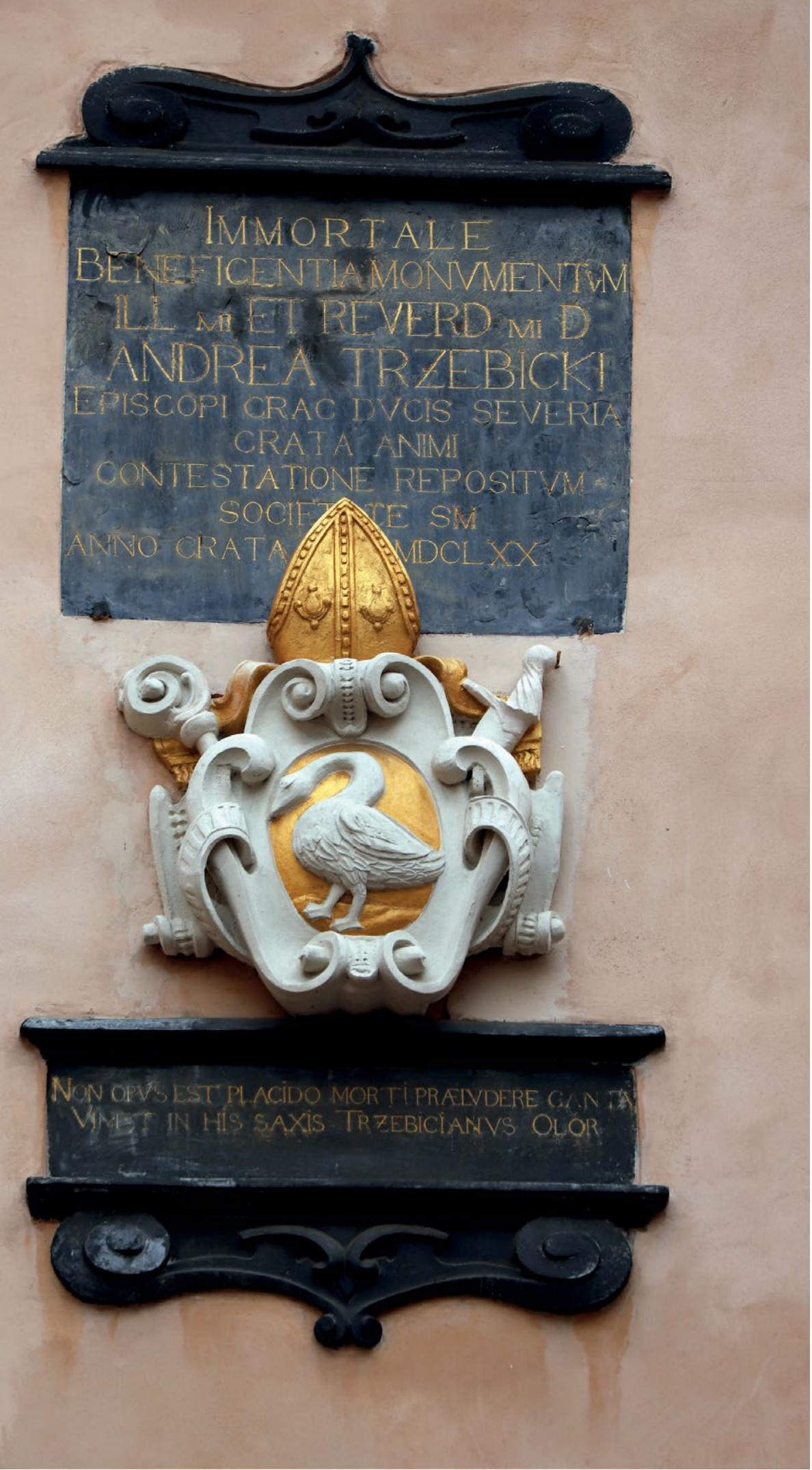

17. Tablica pamiątkowa, 1670 r., kolegium jezuitów przy

kościele pw. św. św. Piotra i Pawła, Kraków. Fot. M. Walczak 
panegirystów, pisarzy, autorów inskrypcji, upatrywać należy w literaturze humanistycznej odwołującej się przede wszystkim do kultury antycznej. Z pewnością ważną role odgrywały opracowania heraldyczne. Szymon Okolski w swoim słynnym Orbis Polonus opublikowanym w 1641 r. opisuje i obszernie objaśnia znaczenia figury łabę dzia ${ }^{142}$, po czym wymienia pieczętujące się nią osoby ${ }^{143}$. W kontekście omawianego medalu szczególnie interesujący wydaje się ustęp zatytułowany Candor animi, w którym autor obszernie dowodzi, że: Nullus Symbolice veritatem exprimendo praemitSymberce verita tere voluit, guod Cygnuscandoren animi significet . Powoluje się przy tym na powszechnie znane dzieła emblematyczne ${ }^{145}$ czyli Emblemata Andrei Alciatiego (emblem 184, opisany jako „Insignia Poetarum”: zawieszona na gałęzi drzewa tarcza $\mathrm{z}$ łabędziem, w tle jezioro z pływającą parą łabędzi) ${ }^{146}$, a także Pieria Valeriana („Anim candor": łabędź na tle szuwarów)|'47. I dalej: Candorem ergo animi vera sapientia conco"Candur guam Cygnus optime hierogliphce mitatur, quam Cygneptime hier repraesentat . Ostatni, sumujący passus można by wprost odn nese do Andrzeja Trzebickiego jako senatora i pasterza: „Haec itaque duo Clarissima Prosapia Cygnorum

142 S. Okolski, Orbis Polonus, t. 2, Cracoviae 1641, s. 1-6. 143 Tamże, s. 6-17

144 Tamże, s. 4.

145 Na temat źródeł wykorzystywanych przez Okolskiego w erudycyjnych wykładach znaczeń
poszczególnych figur heraldycznych zob. B. Milewska-Waźbińska, Biblioteka antyczna Szymona
Okolskiego. Na marginesie lektury Orbis Okolskiego. Na marginesie lektury Orbis Polonus, Serii Nowej, t. 13 (24), 2014, s. 153-159.

146 A. Alciati, Emblemata cum commentariis Claudi Minois I.C. Francisci Sanctii Brocensis \& notis Laurentii Pignorii Patavini, Patavii 1621, s. 767-772.

47 P. Valeriano, Hieroglyphica, sive de sacris Aegyptoru aliarumque gentium literis commentarii, Lugdun 1602, s. 229-230 (szerzej o łabędziu, ks. XXI

148 s. Okolski, dz. cyt.. s. 4.
\& Superstites Duniniorum vobis adscribere icebit; candorem animi, \& vitrutem bonitat apientissime iunctam. Ea namque duo patriae, in negotio praegnanti, $\&$

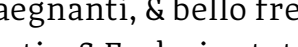
\&enti, muliores declaratis, \& Ecclesiae toto pectore semper \& ubique consecratis, \& Reg Serenissimo, Regno Daniae occasione sib porrecta exhibuitis. Quapropter candore candidati Senatores regni, rectitudine animi, optimi pastores Ecclesiarum, vivite, florete, permanete in tempora, \& aevum ${ }^{\prime 149}$. Prześledzenie motywu łabędzia w kulturze europejskiej przekracza ramy niniejszego opracowania. Warto jed nak wspomnieć o jego wykorzystanju wak wson szczegónej sferze, jaką były odznaczenia. Cho Order Łabędzia, ufundowany w 1440 przez elektora brandenburskiego Fryderyka II (1437/40-1470), jako dworskie odznaczenie Hohenzollernów, a we Frankonii założony w r. 1459 przez margrabiego Albrechta Achillesa von Brandenburg-Ansbach (1437/40-1486). Celem ustanowienia tego zakonu orderowego było związanie szlachty z dynerowe by Siedzibą frankonskiej gałęzi była kapl w. Jerzego w kościele św. Gumberta w Ansbach ${ }^{150}$. Osobnym zagadnieniem jest obecność wyobrażeń łabędzia na monetach i medalach. Pojawiły się one już w numizmatyce antycznej, czego dowodem są monety miasta Klazomenaj (na awersie głowa Apolla, na rewersie postać łabędzia): tetradrachma z lat ok. 375-360 p.n.e. ${ }^{151}$ oraz drachma $z$ lat ok. $375-365$ p.n.e. ${ }^{152}$

\section{Tamże, s. 5.}

150 https://www.historisches-lexikon-bayerns.de/ 1 Cacomplow

Museen zu Berlin nr inw - 18216497, 18216496 https://ikmk.smb.museum/object??d=18216497; https://ikmk.smb.museum/object?id=18216496 [dostęp 4 IV 2020].

152 Egzemplarz w Münzkabinett der Staatlichen Museen zu Berlin, nr inw. 18259148, https:///kmk.smb.
Nieco uwagi poświęcić trzeba lemmie, towarzyszącej herbowemu ptakowi na rewersie medalu Andrzeja Trzebickiego: candore". Przyktadem użycia tego ,h tego "hasta" w emblematyce jest dzieło niemiecki poety Konrada von Hövelen, wydane w Lubece w r. 1667 pod tytułem „Deutsche Zimber Swan". Na stronie przedtytułowej przedstawiono autora ze wstęgą z podwieszonym emblematem Orderu Łabędzia i napisem: „Candorin”, na następnej kompozycje z dewiza „Candore Virtute Honore” Wymienne wykorzystanie słów olor" i, cygnus" 154 , ich znaczeń i skojarzeń odnaj" "cygnus" ic ich znacy odnaj-

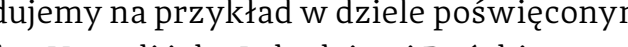
sw. Urszuli jak tabędziowi Reńskienu. ego autor, jezuita Peter Lej ha de Munquintin wykorzystuje dla gloryfikacji kolońskiej Męczenniczki zestawienia bieli łabędzia oraz czerwieni krwi, wiążąc je przy tym zręcznie w tekście dedykacyjnym dla arcyksięcia Leopolda Ksawerego $z$ heraldycznymi barwami Habsburgów: candore cygni, \& cruoris purpura, candidum, do cubicum, turus". Podkreśla czystośc turus. Podkréla czystośc charakteryzują cą upierzenie ptaka, chocby w takiej frazie, ak: „Rhenanus Cygnus, innocentiae candore (podkr. - K .J. Cz., M. W.) candidus, profusi sanguinis ostro rubicundus". Warto też przytoczyć przymioty, którymi cechuje się tabędź: „Splendidissime coelestis Olor tegitur, regali licet trabea nudatus, cui pro plumis candidis, candor est innocentiae ab omni scelerum illibatus afflatu, securus inmis in ver illecevidus inter spicula, fortis inter vulnera, nec dus" ${ }^{\prime s 5}$. Zauważano również obecność tego

53 C. von Höveln, Candorins Deutscher Zimber Swa Lübek 1667; B. Bei der Wieden, dz. cyt, s. 154 B. Bei der Wieden, dz. cyt., s. 21, 265-266.

55 P.L. de Munquintin, Cygnus Rhenanus coelo illatus in ptaka w Biblii ${ }^{156}$. Jako symbol czystości występuje łabędź również wśród symboli odnoszących się do Matki Boskiej.

Nie można pominąć obecności łabe dzia w ikonosferze reformacyjnej, przede wszystkim w związku z osobą Marcina Lutra $^{157}$, a szczególnie jego występowania na medalach emitowanych z okazji 100. i 200. rocznicy ogłoszenia tez wittenberskich $(1617,1717)^{158}$. Na części z nich ptak towarzyszy postaci Marcina Lutra jako jego atrybut ${ }^{159}$, na innych stanowi samodzielny motyw o charakterze emblematycznym, zazwyczaj umieszczany na rewersie ${ }^{160}$ W niektórych przypadkach ko lemma W medalu wybitym w mieście Gotha zamieszczono na rewersie inskrypcję wyjaśniającą ideę wiązania łabędzia z ojcem reformacji, jako kontynuatorem dzieła Jana Husa

156 H.H. Frey, Therobiblia: Biblisch Thierbuch, Leipzig 1595, k. 122v-123r.

$77 \mathrm{O}$ znaczeniach nadawanych łabędziowi w luteranskiej teologii zob. B. Bei der Wieden, dz. cyt., s. 177-180. Na temat łabędzia jako emblematu Marcina Lutra istnieje obszerna literatura, m. Verklärung eines grossen Mannes: Katalog zur Ausstellung in der Lutherhalle Wittenberg anlässlich des 450. Todestages von Martin Luther vom 21 . Februar bis 10. November 1996, Berlin 1996 (V. Joestel, Einleitung: Die Gans und der Schwan. Eibe Allegorie So wurde der Schwan zum Luther Emblem, s. 62-65; G. Seib Luther mitdem Schwan als Frontispize in hessischen Gesangbüchern, s. 66-69; J. Strehle, Luther mit dem Schwan, s. 81-118).

58 H.G. Kreußler, D. Martin Luthers Andenken in ünzen nebst Lebensbeschreibungen merkwürdiger Zeitgenossen desselben, Leipzig 1818, s. 1, 3-4, 6-7, 14 62, 71-72, 76. Zob. tez::P. Arnold, H.-P. Hasse, Luther zum Reformationsiubiläum 1617, „Sächsische Heimatblätter: Zeitschrift für sächsische Geschichte, Denkmalpflege, Natur und Umwelt" 2017, nr 63,

159 Tamze, s. 14, poz. I, s. 62, poz. II, s. 71-72, poz. I.

160 Tamże, s. 1, poz. I, s. 3, poz. VII-VIII, s. 3-4, poz. I, s. 4, poz. III-IV, s. 6-7, poz. I (na awersie), s. 72, poz. II, s. 76

161 Tamí, s. 4, poz IU-IV, s. 6-7, poz I. 
(czeskie husa - gęś): „Martinus Luther sacro sanctae theologiae doctor olor antehac dictus Husso melos ergo terra cantavit" Według legendy czeski reformator miał powiedzieć przed spaleniem podczas soboru w Konstancji w $1415 \mathrm{r}$.: „Dzisiaj piecze się gęś, lecz z jej popiołów powstanie łabędź" Jakkolwiek w kontekście katolickiego biskupa Andrzeja Trzebickiego nie spotyk się jakichkolwiek śladów nawiązań do tej symboliki, to z całą pewnością wśród wykształconych odbiorców medalu krakowskiego hierarchy takie skojarzenia musiały się pojawiać. Być może nawet łabędź

Trzebickiego mógł być traktowany jako ortodoksyjne przeciwstawienie atrybutowi herezjarchy.

Właśnie w kontekście sporów międzywyznaniowych medal krakowskiege biskupa zyskał niezwykle interesujące i niekonwencjonalne odczytanie we wspomnianym wcześniej opracowaniu kolekcji króla Fryderyka I w Berlinie. Zasługuje on na przytoczenie i szersze omówienie, także na przytoczenie iszersze, ta jako autoctycacti numizmatuzczasubiskiego jego emisji. Opracowanie Lorenza Begera nie jest zwyczajnym katalogiem numizmatycznym. N jest także prostym wyborem najcenniejszych dzieł. Jego przemyślna konstrukcja służy zapoznaniu czytelnika z rozważaniami na szereg tematów, wśród których szczególnie eksponowane miejsce zajmują zagadnienia historyczne, religijne

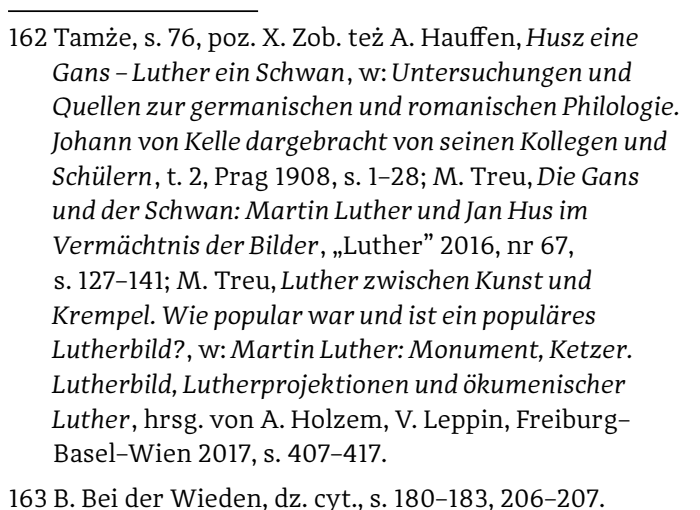

i moralne. W ujęciu Begera: „Die Münzen bieten Anlass für gelehrte Betrachtungen zu Mythos, Ikonographie, Gesc Uunst"164. Medale poznajemy dzięki wi dwóch zwiedzających kolekcję erudytów o dziwacznych, archaizowanych imiohach: Dulodorusa ${ }^{165}$ i Nearistozetusa. Znamienne, że swoją wizytę w rezydencji króla Fryderyka I rozpoczynają od wysłuchania kazania w nowej, wspaniałej kaplic dworskiej ${ }^{166}$. Po tym następują kolejne rozdziały poświęcone numizmatom reprezentującym różne podmioty tak ze sfery duhownej jak i świeckiej Na początek mówione zostały medale papie chieskie, dobranedług przemyslanego klucza, których . nej interpretacji. Dla zrozumienia przewodniej myśli wywodów Begera istotna wydaje się wyrażona przez Nearistozetusa uwaga o niezwykle licznej reprezentacji numizmatów zwierzchników Kościoła rzymskiego w zbiorze króla, patronującego przecież reścijaństwu zreformowanemu'

$W$ przypadku pierwszego z nich, reprezentującego pontyfikat Marcina $\mathrm{V}$, $\mathrm{z}$ wizerunami uroczystego konsystorza oraz Sądu Ostatecznego o wyborze zdecydowała hitoryczna proweniencja - był on darem papieża Aleksandra II dla księcia pomorskiego

\section{B. Weisser, 150 Jahre Münzkabinett. Menschen} Nachrichtenblatt" 2019, nr 68, s.46.

165 Imię oznacza z greckiego dulo" newornika lub człowieka na stużbie, można so identyfikować z samym Lorenzem Begerem. B. Weisser, dz. cyt. s. 45, 54, przyp. 3. W trzytomowym opracowaniu monet antycznych (Thesaurus Brandenburgicus Selectus, 1696, 1698, 1701) Dulodorus dialoguje z mieniem asystent Begera Johann Casimir Philippi. Tamże, s. 45-46, 54, przyp. 4 .

166 L. Beger, dz. cyt, s. 2-4 (na s. 3 ukazano wnetrze opisywanej kaplicy z postacią kaznodziei na ambonie).

167 Tamże, s. 4: „Se sistunt. Numerosa iste! exclamavit Nearistozetus. Tantam sane apud Regem Religion
Bogusława X w 1497 r.168 Dalsze reprezentowały pontyfikaty Sykstusa IV (Rok Święty 1470 r. ${ }^{169}$ Aleksandra VI, Juliusza II, Leona X, Hadriana VI, Klemensa VII, Paw L II, Juliusza III, Marcelina II, Piusa IV, Piusa V, Grzegorza XII, Sykstusa V, Klemensa VII, Leona X, Pawła V, Urbana VIII, Innocentego X, Aleksandra VII, Klemensa IX, Klemensa X, Innocentego XI, Aleksandra VIII'170. Każdy medal został dokładnie i wszechstronnie naświetlony od strony ikonograficznej i historycznej. Zgodnie z hierarchią duchown po papieżach następowali kardynałowie iarcybiskupi ${ }^{171}$.W tak znakomitym towa rzystwie znalazł się również Andrzej Trzebicki reprezentowany medalem w srebrze, omówionym na końcu rozdziału. Komentarz Begera trzeba zacytować w całości:

„Numisma argenteum Andreae Trzebicki, episcopi Cracoviensis, candorem celebrans.

Non Dei tantum, excepit Nearistozetus, sed \& Apostolicae sedis Hic Gratiam agnoscit: Ita enim legitur: Andreae Trzebicki Dei s Apostolicae Sedis Ga Trebicki Dei Cracoviae, Dux Severiae. Recte hoc, respo dit Dulodorus, nec mirandum in Praesule Romanae Sedis devoto, cum apud hos raru non sit, Pontificem Deo aequare; Quandam quod Pontificum Gratia Episcopatus tribuantur, Ducatus autem a Deo recognosci soleant, dei Gratiam ad Ducatum Severiae, Gratiam Sedis Apostolicae autem ad Episcopatum haud forsan abs ratione referas. Quiquid autem sit, illud tamen laudandum, guod Candorem animi fuit hic Praesul jactet; Cygnum enim expressit,

168 Tamże, s. 5-9.

169 Tamże, s. 9-12 (określony jako , ,rarissimum”,
nienotowany w opracowaniach medali papieskic 170 Tamże, s. 12-66.

171 Tamże, s. $66-75$ (kard. Armand Jean Richelieu, kard. Jules Mazarin, abp Moguncij Johann Philipp von Schönborn, abp Trewiru Johann Hugo von Orsbeck inscripsitque: Candore. Cygno, excepit Nearistozetus, etiam Lutherus adumbratur, sed in mentem mihi venit, quod Grammondus in Hist. Galliae ait, Cygnum quidem candidum plumis, sed cute nigerrimum esse. Quid? An id judicii etiam in Trzebikium torquebimus? Quod in Grammondo damnas, respondit Dulodorus, ut imiteris, suadere non possum. Candor etiam errantes ornare posset, si errores suos rationibus convicti deferant, nec contra scientiae suae dictamen defendant. Trzebikium sane tali candore decorum, vel inde credo, fuisse, quod Pufendorfio ${ }^{172}$, in Gestis Friderici Wilhelmi $M$. Elect. Brand ${ }^{173}$ Referente, cum Electoris cum Republica pactum ea ratione oppugnasset, quod se inscio hoc factum fuisset; ad informationem tamen, qua tunc rem ad ejus dignitatem non spectasse edoctus est, justitiae cessit, Electorisque deinceps partes amplexus est. Sed Orbis Romano-Catholici sidera ut relinquamus, Ejus Antagonistae monent ${ }^{{ }^{1} 174}$

$$
\text { Zwrócenie uwagi na tytulaturę kra- }
$$
kowskiego biskupa, wydawałoby się tak konwencjonalne, że nie zasługujące na pogłębiony komentarz, rzuca światło na stosowaną w przeszłości metodę odczytu znaczeń numizmatów daleką od dzisiejszych standardów. W zależności od wiedzy, zainteresowań, narodowości, przynależności państwowej, poglądów politycznych i religijnych, różni autorzy zwracali uwage na różne elementy i komentowali je w dość

172 Samuel von Pufendorf (1632-1694) pseud. Severinus de Monzambano, prawnik, filozof i historyl profesor uniwersytetów w Heidelbergu, a nastepnie mie, wr 1688 przeniósł się do Berlina na dwór brandenburski, gdzie pracowat jako nadworny historiograf. K. Luig, Pufendorf, Samuel Freiherr von, w: Neue Deutsche Biographie, t. 21, München 2003, s. 3-5.

S. Pufendorf, De rebus gestis Friderici Wilhelmi Magn lectoris Brandenburgici commentariorum libr

174 L Beser, dz. cyt, s. $75-76$. 
dowolny sposób, często w zależności od aktualnego kontekstu.

Tytulatura Dei et Apostolicae Sedis gratia", powszechnie używana przez biskupów i arcybiskupów Kościoła katolickiego, weszła w zwyczaj w XII w. ${ }^{175}$ i oznaczała objęcie stanowiska z prowizji papieskiej. Przykładem jest używanie powyższej formuły przez biskupa Macieja z Gołańczy, w przeciwieństwie do jego poprzedników w diecezji kujawskiej, tytułujących się najczęściej tylko „Dei gratia" ${ }^{176}$. Tytuł ten wprowadzony został powszechnie po soborze Trydenckim, chociaż w Polsce jeszcze do XVII w. zdarzały się przypadki stosowania wersji wskazującej jako źródła władzy samego Boga ${ }^{177}$. W przypadku Andrzeja Trzebickiego pełna tytulatura występuj np. w panegiryku Jana Dziedzica Olor Trebicianus, dedykowango z okazji krakowskiego ingresu: „D. Andreae Trebicii, Dei, et Apostolicae Sedis gratia, Episcopi Cracoviensis, Ducis Severiae"

$$
\text { Katolicki pogląd na pochodzenie wła- }
$$
dzy biskupiej podważano w kregach konfesji reformowanych, szczególnie w kontekście poglądów na naturę urzędu biskupa. Komentarzem może służyć późniejszy od naszego medalu, ale reprezentatywny także dla realiów mu współczesnych tekst autorstwa luterańskiego duchownego przeznaczony na wigilię Zesłania Duch

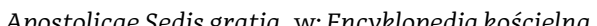
dz. cyt., t. 1, Warszawa 1873, s. 346; A. Sotkiewicz I. Fijatek, O Otytułowaniu się biskupów w wiekach Średnich przez wyrazy „dei et apostolicae sedis gratia ",
Przewodnik Naukowy i Literacki" 1893, nr 21, „Przewodnik Naukowy i Literacki" 1893, nr 21,
s. 414-421; FJ. Schaefer, Dei gratia; Deiet Apostoli s. edis gratia, w: The Catholic Encyclopedia, t. 4, New Sedisgratia, w: The Cr
York 1908, s. 679 .

176 J. Maciejewski, Biskupstwo włoctawskiei ijego kujawsko-pomorscy ordynariusze w Polsce piastow-
skiej. Stan i perspektywy badan, w: Historiograficzn prognoza 2000: stan i potrzeby badań nad dziejami regionów kujawsko-pomorskiego i sasiednich, red

M. Grzegorz, Bydgoszcz 2000 ,
Swiętego $0^{178}$. Znajdujemy w nim przeciwstawienie biskupów pierwotnego Kościoła, powoływanych „Spiritus gratia”, i biskupó w "Wócioła rzymsko-katolickiego, którzy wedug Marcina Lutra „nec esse velle veros episcopos, sed politicos dynastas, qui nec concionantur et docent, nec baptizant, nec coenam administrant, nec ullum opus et of ficium ecclesiae praestant ${ }^{n_{179}}$. Autor przytacza też zdanie Caspara Zieglera (1621-1690): „Habent vero suos principatus, [...] sua insygnia territoria, propter quae eos ut principes reveremur, et majestatem eorum bservanter colimus; sed profecto dum epicopi esse volunt, nec ea tar scopi esse volunt, nec ea tanen, quae episcoporume prorsus erit nomen, neque significantium mplius sui" ${ }^{180}$. O tytulaturze odwołujące się do łaski papieża pisze: „De apellatione Apostolicae sedis plura dici possent, cum abunde constet, apostolicas sedes atque ecclesias olim dictas fuisse omnes, quae ab Apostolis fundatae credebantur, et ab Apostolis horumque doctrina originem suam derivabant. Quod autem Romanae sedi hodie, quasi per eminentiam et cum exclusione aliarum, vindicetur, in vulgus notum est, pertinentque ad artes, quibus papalis dignitas evehi solet". Cytuje przy tym znamienne zdanie nawiązujące do dzieła słynnego katolickiego historyka: „Bellarminus consueta fraude sedem apostolicam cum apostolico praesule confundit"181. Tłumaczy następnie, że dawna, oznaczająca pokore formuła „z łaski Boga” utrzymała się długo, aż do XV w., kiedy prón książętom, sed his missis, in aetatem

178 K.G. Hoffmann, De titulo episcopali Sedis Apostolicae gratia, Vittenbergae 1768

179 Tamże, s. IV, przyp. a.

80 Tamże, s. IV-V, przyp. a. Cytat pochodzi z: C. Ziegler, Eionpožudov Ecclesiasticum, sive Episcopus Miles in

81 Tamże, s. V, przyp. b. atque caussas inquiramus, propter quas sedis apostolicae gratiae suam episcopalem dignitatem adscribunt plerique episcopi pontificii" ${ }^{\prime \prime 82}$.

Lorenz Beger przechodzi następnie do postaci łabędzia, który ma czarną skórę ukrytą pod białymi piórami, co można interpretować jako dwoistość, nieczystość in tencji, hipokryzję. Przypomina, że ptak ten łączony jest z Marcinem Lutrem, powołuje się na świadectwo historiografa francuskiego, który komentował rocznice reformacji obchodzoną w 1617 r., przywołując jubileuszowe medale wybite przez miasta niemieckie (Frankfurt, Wormacje

i Norymberge): „,Nurembergense mensae superimpositam lampadem ostendebat, posito subtus modio, in haec verba: Jam lucet omnibus modio remoto. Ex adverso assurgebat Olor, capite coronato, his circum characteribus, JEHOVA: numismati haec errat inscriptio: Olor invictus virtute divina, hinc ducta ut audio in Lutherum religione, quod Concilio Constantiensi habito annum circa M.CCC XV. Husium haeresiarcham, circa in proximo esset subeunde quam meruerat in proximo esset subeunde quam

poenae, exclamasse fidem faciunt cem datis, cujus e cineribus centum abhinc an cem datis, cujus e cineribus centum abhinc annis olor redivivus emerget: ansere designans seipsum, quippe lingua Boëmica, Hus, anserem significat; olore Lutherum centum post annos haeresiarcham, quem Lutherani fatidica sic voce praenunciatum velut a Deo jactant, nescio unde ducto ab olore in

Lutherum augurio; nisi quod olor nigra intus carne, pelle extima albus est, quod probe haereticis convenit passim hypocritis. Olor amphibium animal est, utrique elemento aeque debitum, qualis Luthero vita fuit, primum Catholico Romano, \& inter Catholicos Monacho, postmodum apostatae, \& haeretico" ${ }^{183}$.

20 Tamìe s. VIII

183 G.B. de Grammond, Historiarum Galliae ab excessu
Najciekawsza, a zarazem trudna do wyjaśnienia jest kwestia moralnego osądu ka zaangażowanego w sprawy polsko-brandenture -brandenburskie. Beger powołuje się przy tym na wielkie historiograficzne opracowanie Samuela Pufendorfa, najpewniej mając na myśli następujący passus: „Regis qvogve Bohemiae supremum imperium cum suffragio in electione Caesarum ferendo citra contoversiam cosistere. Nec eo minus servando Electoris juri Hoverbegvius ${ }^{184} \mathrm{hu}-$ jus suffragium pro eligendo Rege Joanne ei ipsi offerebat, ut tabulario Regni insereretur Qvod Rex facturum se promittebat, pratur. Qvod Rex facturum sepromittebat, pratum, sedvod a solm propter armunentum, sed \& gvod a tam magno ac potente Principe proficiscatur, sibi admodum honorificum sit. Reges gvogve numgvam, sed tantum Rempublicae super eo controversiam movisse. Idem gvogve ab Episcopo

Cracoviensi acceptabatur: sed qvi in testimonio, gvod ejus nomine reddebat, id qvasi suffragium nuncupabat, gvod acceptaritnon quaside jure concessum, sed prout signum benevolentiae \& humanitatis erga suam Majestatem Serenissimum Regem electum. Qvae verba Hoverbegvius dispundi cupiebat; electione Joannis Casimiri illum ipsum Episcopum propria manu ejusmodi testimonium exhibuisse absqve tali clausula. Sed hic respondebat: id se tunc fecisse jussu Primatis, nec eo nomine ad reddendam rationem fuisse obstrictum; qvod nunc secus sit" 185 ,

s. 178

184 Johann von Hoverbeck (1606-1682), urodzony Aleksandrowicach pod Krakowem, dyplomata Wilhelma. M. Hein Johann von Hoverbeck Fin Diplomatleben aus der Zeit des Grossen Kurfürsten, Königsberg 1925; P. Bahl, Der Hof des Großen Kurfürsten. Studien zur höheren Amtsträgerschaft Brandenburg-Preußens, Köln-Weimar-Wien 2001, s.

185 s. 
Mówi on o sporze, który wynikł w czasie elekcji Jana III Sobieskiego. Fryderyk Wilhelm postanowił zaznaczyć wówczas swoje prawa elektorskie i poprosit o oficjalne wpisanie do akt listu gratulacyjnego sformułowanego tak, jakby pruski władca oddawał swoje wotum na wybranego właśnie króla. Sprzeciwił się temu Andrzej Trzebicki, któremu poseł pruski wytknął, że w czasie elekcji Jana Kazimierza podobny dokument wpisał do akt kanclerskich bez zastrzeżeńn ${ }^{186}$.

$$
\text { Zaraz po medalu biskupa krakow- }
$$

skiego Lorenz Beger przechodzi do omówienia medali protestanckich, począwszy od tego wybitego dla uczczenia rocznicy spalenia na stosie Jana $\mathrm{Husa}^{187}$, a nastepnie upamiętniających Marcina Lutra ${ }^{188}$ i Jana Kalwina' ${ }^{189}$. Nieprzypadkowo więc zestawi

186 Sprawe relacjonuje K. Hoszowski, dz. cyt., s. $73-74$, 271-272, a w nowszej literaturze A. Przyboś, $M$. Roż dz. cyt, s. 105; A. Kamieński, Dziatania dyplomaci
brandenburskiej wolsce podczas elekcij 1674 rok brandenburskiej w Polsce podczas elekcii 1674
,Wieki Stare i Nowe" $2015, \mathrm{nr}$ 8(13). s. 41-42. "Wieki Stare i Now"

188 L. Beger, dz. cyt., s. 77-78.

188 Lamże, s. $78-79$. dwa numizmaty, w których pojawiają się tabędzie jako symbole odnoszące się do obozy w obrębie chrześcijaństwa.

Medal Andrzeja Trzebickiego jest dziełem wyjątkowym pod każdym względem. Wykonany z najcenniejszego kruszcu, doskonały technicznie i artystycznie.

W skondensowany, skrótowy sposób prezentuje złożone treści ideowe. Jest przy tym niezwykle rzadki, pożądany przez kolekcjonezwy zo kolekcjo作 wręce czytelinow, mialo za cel przedstawienie tego wybitnego dzieła sztuki medalierskiej, a jednocześnie jego prezentację interpretację z różnych perspektyw. Celem było również postawienie szeregu pytań, na które mimo starań, nie udało się znaleźć odpowiedzi. Mamy nadzieję, że przynajmniej niektóre z nich, w wyniku przyszłych badań, przestaną być aktualne.

\section{STRESZCZENIE}

WOKÓŁ MEDALU BISKUPA

TRZEBNICKIEGO

Artykuł poświęcony jest wysokiej klasy medalowi znanemu z niewielkiej liczby egzemplarzy wybitych w złocie i srebrze ku czci biskupa krakowskiego Andrzeja Trzebickiego (1677). Na awersie przedstawiono popiersie hierarchy w prawo z legendą biegnącą dookoła, natomiast na rewersie wizerunek łabędzia z łacińską dewizą

i datą. Emisja miała miejsca w Gdańsku, a projekt numizmatu wykonał Johann Höh Mł Niestety emitent ani okoliczności zamówienia nie są znane. Kluczowe znaczenie ma prawidłowa interpretacja sygli na awersie: „ATH D.D.D." które dotychczas czytan Andreas Trzebicki honor dat, donat, dedicat". W myśl takiej lekcji sam biskup byłby emitentem medalu ku swojej czci. Autorzy po analizie źródeł zaproponowali wariantywne propozycje odczytu: „Andreae Trzebicki Honori Dat Dedit Dedicat" lub Andreae Trzebicki Haec [numisma?] Data "Decreto Decurion ". Druga lekcja waja Decreto Decurion się prawdopodobniejsza, co skłania do hipotetycznego uznania za emitenta medalu krakowskiej rady miejskiej. Bezpośrednim powodem emisji mogło być popierani przez Trzebickiego starań o uzyskan przez władze Krakowa samodzielności w wybieraniu rajców, dotąd wskazywanych przez miejscowego wojewodę. Starania te miały miejsce w 1677 r. i zakończyły się wydaniem przez króla Jana HI Sobieskiego o powiedniego przywileju (3o grudnia) powiedniego przywileju (30 grudnia) wźwięk apologetyczny i głosi chwałę hiedźwięk apologetyczny i głosi chwałę hierarchy nie tylko przez ukazanie jego wierherbem łabędź, który był interpretowany powszechnie jako symbol czystości. Dewiza Candore odnosi się zarówno do bieli tabędzia, jak do zasad przyświecających biskupowi w życiu prywatnym i działalności

\section{SUMMARY}

CONCERNING AMEDAL OF BISHOP

ANDRZEJ TRZEBICKI

The paper deals with a high-quality and very rare medal issued in honour of the Bishop of Cracow Andrzej Trzebicki in 1677 of which only a few specimens struck in gold and silver are known. Its obverse represents a bust-length image of the prelate turned right, with a legend running around the rim, while the reverse features an image of a swan accompanied by a Latin motto and date. The medal, issued in Gdańsk, was executed after a design by Johann Höh the Youn de Younger. Regrettably, neither the issuer no the circumstances of the medal's commission are known. What is of key importance for determining the above facts is the correct reading of the sigla: 'ATH D.D.D', inscribed on the obverse, which so far have been deciphered as: 'Andreas Trzebicki honor dat, donat, dedicat'. In keeping with this reading, the bishop himself would have been the issuer of a medal struck in his honour. Having analysed documentary evidence, the authors of the present paper have put forward alternative readings of the inscription: 'Andreae Trzebicki Honori Dat Dedit Dedicat' or 'Andreae Trzebicki Haec [numisma?] Data Decreto

Decurionum'. The latter reading seems to be more plausible and suggests that, hypothetically, the medal may have been issued by the Cracow city council. The immediate reason for issuing the medal may have been Trzebicki's support of the strivings of the municipal authorities of Cracow for autonomy in electing members of the city council, which until then were appointed by the local voivode. These efforts took place in 1677 and concluded with a charter issued by King John III Sobieski in Gdańsk on 30 December of that year, granting the city the requested rights.

The magnificent medal reveals an aspect of 
publicznej. Omawiany medal cieszył się od początku szczególnym uznaniem kolekcjonerów, o czym zaświadcza jego dokładna analiza w opracowaniu kolekcji medalikrola Fryderyka I Berlinie autorstwa Lorko Begera (1704) Autor zwrócit uwage na będBegera (1704). Autor zwrócit uwa na błędną z punktu widzenia protestanta tytulaturę hierarchy „Dei et Apostolicae Sedis gratia", a także na ambiwalencję łabędzia jako symbolu czystości (ptak ten ma czarną skórę ukrytą pod białymi piórami, co można interpretować jako dwoistość, nieczystość intencji i hipokryzję).

\section{SLOWA KLUCZOWE}

StowA kLUCzowe ikonografia, epigrafika,

sztuka barokowa eulogising the prelate, and his praise is expressed not only through his faithful likeness depicted on the obverse. Trzebicki

used the 'Swan' coat of arms, and the swan waty. The motto 'C fers to not only the witen the rever fers to not only the whiten of the swan but also to the principles to which the bishop adhered, both in his private life and in carrying out his public duties.

The medal under discussion has from the very beginning enjoyed a special appreciation of collectors, as attested by his detailed nalysis included in a study of the medallic collection of King Frederick I in Berlin, by Lorenz Beger, published 1704. Beger has noted the titulature of the prelate, 'Dei et Apostolicae Sedis gratia' - which he considered incorrect (from a Protestant point of view). Additionally, he pointed out to the ambiguity of the swan as a symbol of chastity, as the bird has a black skin hidden under white plumage, which can be interpreted as duplicity, unfair intentions and hypocrisy.

\section{KEYWORD}

raiture, iconography, epigraphy, baroque art
BIBLIOGRAFIA

Źródła

Alciati A. Emblemata cum commentariis Claudii Minois I.C. Francisci Sanctii Brocensis \& notis Laurentii Pignorii Patavini, Patavii 1621

Annua doloris sacra ilustrissimo ac reverendissimo d. Andreae Trzebicki, episcopo Cracoviensi duci Severiae, a Collegio Cracov: Societatis Jesu, fundatori suo munificentissimo parentali carmine persoluta, Cracoviae 1681.

Beger L., Numismata pontificum Romanorum, aliorumque ecclesiasticorum rariora \& elegantiora: ex cimeliarchi RegioElectorali Brandenburgico, selecta aereque expressa, \& dialogo illustrata, Coloniae Brandenburgicae 170

Benedykt od św. Józefa (Zawadzki), Infula Cracoviensis gemmis suis distincta, Varsaviae 1686.

Bieżanowski S., Cygnvs academicvs, inter suavissimum verbi incarnati concentum, a aeternam felicitatem translatus, et ad feralem vrnam clarissimi olim et adm. Rńdi Domini, M. Mathiae Brvzynski Blosii, Coll:Maioris. S. Th. D. Decani S. Flor. Cancellarii Posnaniensis dignissimi. Lugubri elego [...] in palaestra Cynersciana advmbratus. Anno domini, 1646. Die 17. Decemb., Cracoviae 1646.

Buonanni F., Numismata summorum pontificum templi Vaticani fabricam indicantia, chronologica ejusdem fabricae narratione, ac multiplici eruditione explicata, Romae 1700.

Casseburg G.B. Sammlung preussischer und polnischer Medaillen wie auch Thaler welche auf allerhand Begebenheiten geschlagen und von Seel. Herrn Heinrich Lübeck [...] colligiret, in ihrer Ordnung vorgestellt und kürzlich beschreiben, Königsberg-Leipzig 1737

Corpus inscriptionum Poloniae, t. Województwo Krakows z. 1: Katedra krakowska na Wawelu, wyd. i oprac. A. Perzanowska, Kraków 2002.

Damalewicz S., Constitutiones Canonicorum Regularium Lateranensium Domus Calissiensis S. Nicolai, Romae 1655

Dziedzic J., Olor Trebicianus pontificali pedo, tiara insignitus. Ad primum et auspicatissimum Illustrissimiet Reverendissimi Domini, D. Andreae Trzebicki [...].In Cathedralem Cracoviensis Ecclesiae Basilicam, ingressum ad iuga Vavellini Montis, dulces afflictae Ecclesiae et Patriae cantus modulans, Cracoviae 1658

Dziedzic J., Olor Trebicianus pontificali pedo, tiara insignitus. Ad primum et auspicaissimum Illustrissimi et Reverendissim Domini, D. Andreae Trzebicki [...]. In Cathedralem Cracoviensis Ecclesiae
Basilicam, ingressum ad iuga Vavellini Montis, dulces afflictae Ecclesiae et Patriae cantus modulans, Cracoviae 1658.

Echo Concentus ad Petram refractiseu Panegyricus Gratulatio, Cracoviae 1658

Frey H.H., Therobiblia: Biblisch Thierbuch, Leipzig 1595.

Goltz $\mathrm{H}$. Thesaurus rei antiquariae huberrimus, Antverpiae 1579.

Grammond de, G.B., Historiarum Galliae ab excessu Henrici IV. Libri XVIII,

Francofurti \& Lipsiae 1674.

Gruterus J. [Gruyter Jan], Corpus inscriptionum ex recensione et cum adnotationibus Joannis Georgii Graevii antiquae totius orbis Romani, t. 2, cz. 2, Amstelaedami 1707.

Hoffmann K.G., De titulo episcopali Sedis Apostolicae gratia, 1768.

Höveln von, C., Candorins Deutscher Zimber Swan, Lübek 1667.

In laudes Ioannis Sobescii. Rękopiśmienny zbiór emblematów z rysunkami Johanna Jakoba Rollosa, wstep i oprac. M. Górska, B. Milewska-Waźbińska, Warszawa 2016. 
Jonston J., Historiae naturalis de avibus libri VI, Francofurti ad Moenum 1650.

Kanon A., Lucubrationes oratoriae, Regum, Pricipum, Antististum, caeterorumque Illustrum Virorum Panegyricis \& Elogii insignitae, Cracoviae 1676.

Klaudiusz Elian, O właściwościach zwierzą (wybór), tłum. i oprac. A.M. Komornicka, Warszawa 2003.

Krasicki I.,Zbiór potrzebnieyszych wiadomości porządkiem alfabetu ułożonych, t. 1 Warszawa-Lwów 1781.

Kreußler H.G., D. Martin Luthers Andenken in Münzen nebst Lebensbeschreibungen merkwürdiger Zeitgenossen desselben, Leipzig 1818.

Krzysztanowicz S. Respublica sive status Regni Poloniae, Litvaniae, Prussie, Livoniae, Lugduni Batavorum 1642

Kundmann J.Ch., Die Heimsuchungen Gottes in Zorn und Gnade Uber das Hertzogthum Schlesien in Müntzen, Leipzig 1742.

Liberiusz J., Gospodarz nieba y ziemie Iesus Christus Syn Boży Bog Wcielony Zbawicie y Naprawca Swiata, Kraków 1665.

Makowski S.S., Pars hyemalis concionum pro festivitatibus Christi, B. Virginis et sanctorum a prima Januarii usque a ultimam Junii, Cracoviae 1666

Munquintin de, P.L., Cygnus Rhenanus coelo illatus in diva virgine et martyre Ursula, Viennae 1682.

Okolski S., Orbis Polonus, t. 2, Cracoviae 1641.

Orsato S., De notis Romanorum commentarius, Patavii 1672.

Papczyński J Orator Crucifixus sive ultima Septem Verba Domini Nostri Iesu Christi, Cracoviae 1670

Petrycy F.B., Panegyricus illustrissimo ac reverendissimo principi d. Andreae Trzebicki [...] auspiciato cathedram suam III nonas Novembris Anno D. M. DC.LVIII ingredienti, Cracoviae [1658].
Podgórski J., Certamen votorum inter dioeceses, Cracoviae 1711.

Pufendorf S, De rebus gestis Friderici

Wilhelmi Magni electoris

Brandenburgici commentariorum libri novendecim, Berolini 1695.

Radliński J.P., Imago thaumaturga beatissimae virginis Mariae immaculate conceptae primo Hierosolymitana secundo Constantinopolitana tertio Belzensis qu arto Claro-Montana Czestochoviensis, Cracoviae 1756.

Reichel J., Die Reichelsche münzsammlung in St. Petersburg, t. 2:Liefland, Curland und Polen, [St. Petersburg] 1842.

Rorajski J., Cygnus puri candoris nitor, in Armis, Aula, Senatu, Ecclesia radios diffundens, Illustrissimo et Reuerendissimo Domino D. Andreae Trzebicki Episcopo Cracoviensi, Duci Severiae, Almae Academiae Cracoviensis Cancellario dignissimo, in auspicato ad Episcopatum Cracoviensem ingressu, debitae observantiae ac submissi cultus ergo; officiosissimo, gestientis animi obsequio..., Cracoviae 1658.

Serie dei conj di medaglie pontificie da Martino $V$ fino a tutto il pontificato della San. Mem. di Pio VII esistenti nella Pontificia Zecca di Roma, Roma 1824.

Starowolski S., Vitae antistitum Cracoviensium, Cracoviae 1658.

Thomassin L., Méthode d'étudier et d'enseigner la grammaire ou les langues par rapport à l'Ecriture Sainte \&à la langue Hebraïque, t. 2, Paris 1693.

Valeriano P., Hieroglyphica, sive de sacris Aegyptorum aliarumque gentium literis commentarii, Lugduni 1602.

Verzeichiß der vorzüglich vollständigen Sammlung von Medaillen und Thaler die zum Nachlaß des wohlseeligen Herrn Johann Heinrich Lübeck [...] gehören und den 1oten Sept. 1781. durch eine [...] öffentliche Ausbiethung, denen Münzlieberhabern überlassen werden sollen, Königsberg [1781]
Waśniowski W., Śmierć wielkiego xiążęcia pogrzebowym obżałowana kazaniem przy wyprowadzeniu do grobu ciała [...] x. Iędrzeia Trzebickiego, biskupa krakowskiego [...], w kościele farnym krakowskim dnia 29 miesiaca stycznia Roku Pańskiego 1680, Kraków [1680]

Zachariasiewicz F.K., Vitae episcoporum Premisliensium ritus latini, Viennae 1844

Ziegler C., $\Sigma \iota \delta \eta \rho o \xi u \lambda o v E c c l e s i a s t i c u m$, sive Episcopus Miles in veteri ecclesia invisus, Wittenbergae 1672

\section{Opracowania}

Oorytasów numizmatycznych $w$ Muzeum Narodowym w Krakowie, Kraków 2012 Apostolicae Sedis gratia, w: Encyklopedja kościelna podług teologicznej encykloped i Wetzera i Weltego, t. 1, Warszawa 1873 , s. 346.

Arnold P., Hasse H.-P., Luther und der Schwan: eine Medaille von Christian Maler zum Reformationsjubiläum 1617, Sächsisch Heimatblätter: Zeitschrift für sïschHeimatblattur: Zeitschreur sächsische Geschichte, Denkmalpflege, 63, s. 151-160. Sigismund von Chelminski, Szarawk (Russland). Münzen und Medaillen von Polen und sonstige auf Plen bezügliche Gepräge. Montag, den 25. April 1904 und folgende im Locale und unter Leitung des Experten, Otto Helbing München, Maximilian strasse 13/Ilinks, Mïnch,

Ausberger L., Burdette R.W., Orosz J., Truth Seeker: The Life of Eric P. Newman, Dallas 2015.

Baczewski S.,Panegiryk jako narzędzie komunikacji społecznej. „Charites Słowieńskie” Jana Zawickiego i „Eabęć żałośnie śpiewajaccy" Hiacynta Przetockiego, w: Panegiryk jako element życia literackiego doby staropolskiej ioświeceniowej, red. M. SulejewiczNowicka, Z. Gruszka, wstep $M$. Wichowa, tódź 2013, s. 35-47.

Bahl P. Der Hof des Großen Kurfürsten. Studien zur höheren Amtsträgerschaft Brandenburg-Preußens, KölnWeimar-Wien 2001

Barycz H., Lata szkolne Marka i Jana Sobieskich w Krakowie, Kraków 1939

Barycz H., Rzecz o studiach w Krakowie dwóch generacji Sobieskich, KrakówWrocław 1984

Bender A., Wzorzyste włoskie tkaniny jedwabne z polskimi herbami w XVI iXVII wieku, w: „Pod niebem Pótnocy”. Z dziejów polsko-włoskich związków artystycznych, red. P. Kondraciuk Zamość 2010, ss. nlb.

Bentkowski F., Spis medalów polskich lub $z$ dziejami krainy polskiej stycznych, w Gabinecie Król. Alekx. Uniwersytetu w Warszawie znajdujacych się, tudzież ze zbiorów i pism rozmaitych lub podan zebrany i porzadkiem lat ułożony, Warszawa 1830.

Betlej A., Baranek (i lwy). Przykłady wykorzystania znaku herbowego $w$ dekoracjach artystycznych w XVIII wieku, w: Ex voto. Studia dedykowane Ojcu Janow Golonce OSPPE w 75. rocznicę urodzin i w 50. rocznicę święceń kapłańskich red. P. Mrozowski, J. Żmudziński, Jasna Góra 2012, s. 503-509.

Bieniarzówna J., Małecki J.M., Dzieje Krakowa. Kraków w wiekach XVIXVIII, Kraków 1984.

Biskupstwo wrocławskie w numizmatyce isfragistyce. Katalog wystawy w Muzeum Narodowym we Wrocławiu, V-XI 1997, wyd. B. Marcisz, M. Karnicka, Wrocław 1997.

Buchwald-Pelcowa P., Emblematyka w póź nobarokowych drukach polskich, „Biuletyn Historii Sztuki”, r. 42, 1980, nr 3-4, s. 401-412.

Cahn A.E., Frankfurt am Main, Niedenau 55. 
Versteigerungskatalog Nr. 66.I. Sammlung Antiker Münzen Griechen, Römer, Byzantiner und Barbarenmünzen, Nachlaß eines ausländischen Adligen. II. Sammlung Russischer Münzen enthaltend viele Seltenheiten z. Teil aus nordischem Besitz. III. Münzen und Medaillen Europäische Länder aus verschidenem Besitz. Anschliessend Auktion 67 Nuismatische Bibliothek des verstobenen Herrn Geheimrat Prof. Dr.h.c. Ferdinand Friedensburg. Die Verstiegerung findet im Auftrag der Besitzer statt Dienstag, 6 Mai 1930 u. folg. Tage zu Frankfurt am Main, Niedenau 55, München 1930.

Chełmiński A. Z., [nekrolog], w: „Wiadomoś Numizmatyczno-Archeologiczne", t. 16, 1905, $\mathrm{nr} 3$ (63), szp. 335.

Chiai G.F., Das Münzporträt in der Renaissance, w: Vorträge zur Geldgeschichte 2012, hrsg. von. R. Walburg, Frankfurt am Main 2013, s. 5-39.

Czapla J., Miedzy autorem a drukarzem. Dobór ilustracji w „Historia naturalis” Jana Jonstona, „Zeszyty Naukowe Towarzystwa Doktorantów UJ. Nauki Społeczne" 2016, nr 14, s. 9-25.

Czarski B., Lemmata w staropolskich konstrukcjach stemmatycznych jako przejaw hybrydyzacji gatunkowej, „Terminus”, t. 14, 2012, z. 25, s. 157-178.

Czarski B Stemmaty w staropolskich ksigżkach, czyli rzecz o poezji heraldycznej, Warszawa 2012.

Czarski B., Recepcja antycznej ikonografii monetarnej w XVI-wiecznych drukach emblematycznych (projekt badawczy Biblioteki Narodowej), ,Rocznik Biblioteki Narodowej” 2015, nr 46 , S. 109-134.

Czyżewski K.J., Wystawił dwie kolumny, a na wierzchu kolumn robotę na kształt lilyi położył, w: Ex voto. Studia dedykowan Ojcu Janowi Golonce OSPPE w 75 . rocznicę urodzin i w 50. rocznicę święceń kapłańskich, Jasna Góra 2012, red. P. Mrozowski, J. Żmudziński, Jasn Góra 2012, s. 603-625.

Czyżewski K.J., Wystawił dwie kolumny, a na wierzchu kolumn robotę na kształt lilyi położył, w: Ex voto. Studia dedykowane Ojcu Janowi Golonce OSPPE w 75. rocznicę urodzin i w 50. rocznicę święceń kapłańskich, Jasna Góra 2012, red. P. Mrozowski, J. Żmudziński, Jasna Góra 2012, s. 603-625.

Czyżewski K.J., Kapa pontyfikalna Piotra Tylickiego-konteksty, w: Tekstylia w zbiorach sakralnych. Inwentaryzacjakonserwacja-przechowywanie, red. H. Hryszko, A. Kwaśnik-Gliwińska, H. Hryszko, A. Kwaśnik-Gliwińska,
M. Stachurska, Warszawa 2013, 175-195. zyżewski K.J., Wawelska kapa biskupa Piotra Tylickiego w Piotrawinie - rekapitulacja, w: Zespół zabytkowy Piotrawina - promocja dziedzictwa. Materiały z ogólnopolskiej konferencji naukowe poświęconej podsumowaniu badán archeologicznych i prac remontobo wo-konserwatorsich w zespole sakralnym w Plotrawinie prowadzonych w latach 2011-2013 oraz wybranym zabytkom zgromadzonym na wystawie przy kościele parafialnym, red. R. Bartnik, Piotrawin 2014, s. 226-231.

Daranowska-Łukaszewska J., Nagrobek biskupa Andrzeja Trzebickiego w kościele śś. Piotra i Pawła w Krakowie,

„Biuletyn Historii Sztuki”, r. 39, 1977 nr 2, s. 177-19o.

Encyklopedja kościelna podług teologicznej en cyklopedji Wetzera i Weltego, t. 29 Warszawa 1907

Fabiański M., O jezuickim nagrobku biskupa Andrzeja Trzebickiego, „Folia Historia Artium", Seria Nowa, t. 10, 2005, S. 127-160.

Fabiański M., Śmierć i zmysły w barokowym nagrobku w Krakowie a pisma Daniela
Bartoli S.J, w: Italská renesance a baroko ve střední Evropě. Př́spěvky z mezinárodníkonference. Olomouc 17-18. řijna 2003, red. L. Daniel, Olomouc 2005, s. 185-196.

Fijałek J., O tytułowaniu się biskupów w wiekach średnich przez wyrazy „dei et apostolicae sedis gratia”, „Przewodnik Naukowy i Literacki" 1893, nr 21, s. 414-421.

Forrer L., Biographical Dictionary of Medallists, Coin-, Gem-, and SealEngravers, Mint-Masters, \&c., with references to their works B.C. $500-$ A.D. 1900, t. 7. London 1923

Giardina A, Vauchez A, Il mito di Roma. Da Carlo Magno a Mussolini, Roma-Bari 2008.

Gigilewicz E., Medalologia - medaloznawstwo - medalografia oraz medalistyka i medalierstwo a nauki pomocnicze historii, w: Polskie medalierstwo kościelne - tradycja i współczesność. Konferencja naukowa 17 grudnia 2007 r., red. P. Dudziński, K. Łatak, Kraków 2008, s. 9-23.

Giżyńska-Matecka M. Portretbiskupa Andrzeja Trzebickiego w krużgankach klasztoru OO Franciszkanóww Krakowie, ,Zeszyty Naukowe UJ. Prace z Historii Sztuki” 1977, Z. 14, S. 43-72.

Górczyk J.,Portre Krasińskiego, „Magazyn Informacyjny Muzeum Romantyzm w Opinogórze", t. 5, 2017, nr 1, s. 8-9.

A. Kraków ijego okolice, 1844

Grässe IC T Orbis Latinus. Lexikon lateinischer geographischer Namen des Mittelalters und der Neuzeit, oprac. i red. H. Plechl, współpraca S.Ch. Plechl, t. 3, Braunschweig 1972.

Grodecki R.,Przywilej menniczy biskupstwa poznańskiego z r. 1232, Poznań 1921.

Gumowski M.,Kollekcya monet i meda P. Z. Chełmińskiego z Szarawki, „Wiadomości Numizmatyczno-
Archeologiczne", r. 15, 1904, nr 1, szp. 79-81.

Gumowski M., Studia nad gdańską sztukq medalierską XVII w., „Wiadomości Numizmatyczno-Archeologiczne", t. 10, 1924, nr 10, s. 23-64.

Gumowski M., Prawo mennicze biskupów polskich $w$ wiekach średnich, „Ateneum Kapłańskie", 1926, nr 17-18, s. 1-9.

Gumowski M., Gdańs w: Gdańsk. Przeszłośći teraźniejszość, red. S. Kutrzeba, Lwów 1928 s. $440-452$.

Gumowski M., Chełmiński Antoni Zygmunt, w: Polski słownik biograficzny, t. 3 Kraków 1937, s. 278.

Gumowski M. Höhn Jan, w: Polski słownik biograficzny, t. 10, WrocławWarszawa-Kraków 1962-1964, s. 49. Gumowski M., Mennica Gdańska, Gdańsk 1990.

Heenes V., Biographie und Bibliographie von Lorenz Beger, w: Proceedings of the international congress , 300 Jahre

Thesaurus Brandenburgicus", red.

M. Kunze, H. Wrede, Münich 2006, s. $83-96$.

Hein M.,Johann von Hoverbeck. Ein Diplomatleben aus der Zeit des Grossen Kurfürsten, Königsberg 1925.

Heres G., Die Anfänge der Berliner AntikenSammlung zur Geschichte des Antikenkabinetts 1640-1830, "Staatliche Museen zu Berlin. Forschungen und Berichte" 1977, nr 18, s. 93-130, tabl. 21-28.

Heres G. Die Anfänge der Berliner AntikenSammlung zur Geschichte des Antikenkabinetts 1640-1830. Addenda et corrigenda, „Staatliche Museen z Berlin. Forschungen und Berichte" 1980, $\mathrm{nr} 20$, s. 101-104.

Heritage World Coin Auction January 14-16, 2014, New York. Selections from the Eric P. Newman Collection Part III,

New York 2014. 
Hinrichs K., Bernstein, das „Preußische Gold in Kunst- und Naturalienkammern und Museen des 16.-20. Jahrhunderts. Zur Erlangung des akademischen Grades doctor philosophiae (Dr. Phil.), Philosophische Fakultät III der Humboldt-Universiät zur Berlin, 2006.

Höhn Jan, w: Stownik artystów polskich i obcych w Polsce działajacych (zmarłych przed 1966 r.). Malarze, rzeźbiarze, graficy, t. 3, red. J. MaurinBiałostocka, J. Derwojed, Warszawa 1979, s. 94-95.

Hoszowski K., Domy w Krakowie niegdyś braci, Janów Długoszów, Kanoników katedralnych Krakowskich, Kraków 1882.

Hoszowski K., Żywot Andrzeja Trzebickiego biskupa krakowskiego księcia siewierskiego, Kraków 1861.

Hutten-Czapski E., Catalogue de la Collectio des Médailles et Monnaies Polonaises, t. 2, St.-Pétersbourg 1872.

Johann Christoph Gottsched Briefwechsel unter Einfluß des Briefwechsels von Luise Adelgunde Victorie Gottsched, t. 13 Adelgunde Victorie Cottsched, 13 : Januar 1748-Ohtober 1748, hrsg. von C. Kohler, F.Menzel, R. Otto, M. Schlott, Berlin-Boston 2019.

Kaleciński M., Między sfera prywatna a publiczna. ., Ars mythologica" i antykizacja we wnętrzach domów $i$ w ogrodach gdan szczan, w: Gdańsk nowożytny a świat antyczny, red. M. Otto, J. Pokrzywnicki, Gdańsk 2017, s. 115-149.

Kalinowski P., Medale ksiażąt siewierskich. Katalog, Kalety 2010.

Kamieński A Dzialania dyplomacii brandenburskiej w Polsce podczas elekcji 1674 roku, „Wieki Stare i Nowe”, t. 13, 2015 nr 8, s. 41-42.

Karnicka M., Monety dukatowe i talarowe oraz medale biskupów wrocławskic powstate w okresie od XVI do XVIII wieku w zbiorach Muzeum

Narodowego we Wrocławiu, w: Nysa. Sztuka w dawnej stolicy księstwa biskupiego, red. R. Hołownia, $M$.

Kapustka, Nysa 2008.

Katalog zabytków sztuki w Polsce, t. 4: Miasto Kraków, cz. 1: Wawel, red. J.

Szablowski, Kraków 1965.

Kenner F., Beger: Lorenz B., w: Allgemeine Deutsche Biographie, Bd. 2, 1875 , s. $271-272$.

Kiersnowski R., Moneta w kulturze wieków średnich, Warszawa 1988.

Koehne B.-K., Jacob v. Reichel und seine Sammlung, „Zeitschrift für MünzSiegel und Wappenkunde. Neue Folge" 1859-1862, s. 1-24.

Koperwas M., Katalog medali XVI-XVIII w. w zbiorach Gabinetu Numizmatycznego Muzeum Lubelskiego, Lublin 1998.

Krasny P., Nagrobek biskupa Andrzeja Trzebickiego w kościele śś. Piotra i Pawła w Krakowie a plastyka nagrobna Domenica Guidi, w: Między gotykiem a barokiem. Sztuka Krakowa XVI XVII wieku. Materiały sesii naukowej zorganizowanej przez Oddziat Krakowski SHS, red. E. Fiałek, Kraków 1997, s. 113-130.

Krasny P., Figura baranka na kopule kaplicy Załuskich i jej symbolika ,w dwojakim nawet sensie", w: Katedra krakowska w czasach nowożytnych (XVI-XVIII w.), red. D. Nowacki, Kraków 1999, S. 121-128.

Kubala L., Wojna brandenburska i najazd Rakoczego w roku 1656 i 1657, Lwów 1917

Kumor B.S., Dzieje diecezji krakowskiej do roku 1795, t. 1, Kraków 1998.

Ledóchowski A., Notice sur deux médailles Polonaises inedites, qui se trouvent dans le Cabinet Royal de Munich en Bavière, "Koehne's Zeitschrift für Münz-, Siegel- und Wappenkunde" 1842, $\mathrm{nr} 2$ s. 327-330.

Lexikon Abbreviaturarum. Wörterbuch lateinischer und italienischer Abkürzungen, hrsg. von A. Cappelli, Leipzig 1901.

Lorenz Beger, w: L. Noack, J. Splett, Bio-

Bibliographien: brandenburgische
Gelehrte der frühen Neuzeit, BerlinCölln 1688-1713, Berl in 2000, s. 37-44.

Luig K., Pufendorf, Samuel Freiherr von, w: Neue Deutsche Biographie, t. 21, München 2003, s. 3-5.

Luther mit dem Schwan. Tod und Verklärung eines grossen Mannes: Katalog zur Ausstellung in der Lutherhalle Wittenber anlässlich des 450. Todestages von Martin Luther vom 21. Februar bis 10. November 1996, Berlin 1996.

Maciejewski J., Biskupstwo włocławskie i jego kujawsko-pomorscy ordynariusze

w Polsce piastowskiej-stan i perspektywy badań, w: Historiograficzna prognoza 2000: stan i potrzeby badańn nad dziejami regionów kujawsko-pomorskiego i sassiednich, red. M. Grzegorz Bydgoszcz 2000, s. 77-90.

Mańkowski T., Polskie tkaniny i hafty XVIXVIII wieku, Wrocław 1954

Marciniak D., Grosz siewierski biskupa Kajetana Sołtyka, https://gndm.pl/ orosz-siewierski-biskupa-kajetana-soltyka/.

Medale polskie i z Polska zwiazane z okresu Pierwszej Rzeczypospolitej. Katalog zbiorów. Zamek Królewski w Warszawie - Muzeum. Fundacja Zbiorów im. Ciechanowieckich, oprac. J. Zacher, G. Śnieżko, M. Zawadzki, współpraca M. Męclewska, t. 2 Warszawa 2019.

Medale polskie lub do Polski odnoszace sie tudzież medale znakomitych Polaków i ludzi Polsce zasłużonych w zbiorze Piotra Umińskiego, Kraków 1885.

Mikocki L Verzeichniss einer grossen un sehr gewählten polnischen Münzu. Medaillen-Sammlung, Wien 1850

Milewska-Waźbińska B., Biblioteka antyczna Szymona Okolskiego. Na marginesie lektury Orbis Polonus, „Rocznik Polskiego Towarzystwa Heraldycznego", Nowa Seria, t. $13(24)$ 2014, s. 153-159.
Monety biskupów polskich, w: Z. Gloger, Encyklopedja staropolska, t. 3 , Warszawa 1902, s. 222

Nouveau dictionnaire de la conversation ou répertoire universel, wyd. A. Wahlen, t. 9 , Bruxelles 1845 .

Pauk M. R., Moneta episcopalis: mennictwo biskupie w Europie Środkowej X-XIII w. i jego zachodnioeuropejski kontekst, „Przegląd Historyczny”, t. 101, 2010, z. 4, s. 539-571.

Pelc J., Słowo i obraz na pograniczu literatury i sztuk plastycznych, Kraków 2002

Piwocka M., O tkaninach, które zdobią i znacza, w: Tekstylia w zbiorach sakralnych. Inwentaryzacja-konserwacja - przechowywanie, red. H. Hryszko, A. Kwaśnik-Gliwińska, M. Stachurska, Warszawa 2013, S. 152-162.

Podniesińska K., ,... by dzieło to godnym się stało wspomnień głośnego niegdyś po świecie narodu" - jeszcze kilka słów na temat dzieła „Historia polska medalami zaświadczona i objaśniona" Jana Chrzciciela Albertrandiego,

Wiadomości Numizmatyczne", t. 62, 2018, z. 1-2, s. 307-321.

Podniesińska K., Pięć albumów z rycinami medali polskich do dzieła „Historia polska medalami zaświadczona i objaśniona" biskupa Jana Chrzciciela Albertrandego, „Res Gestae. Czasopismo Historyczne" 2016, nr 3, s. 69-95.

Podniesińska K., Trzykomplety „Rycin medali polskich"odbitych z blach Królewskiego TowarzystwaPrzyjaciót Naukw Warszawie przechowywane wzbiorach graficznych Muzeum Narodowego w Krakowie, „Wiadomości Numizmatyczne”, t. 60, 2016, z. 1-2, s. 63-88.

Polkowski I., Medale biskupów polskich, w: Encyklopedja kościelna podług teologicznej encyklopedji Wetzera $i$ Weltego, t. 14, Warszawa 1881, s. 103

Polski indeks biograficzny, wyd. 2. połączone i rozszerzone, oprac. G. Baumgartner München 2004. 
Przewodnik po Muzeum im. Hr. Emeryka Kraków 1908.

Przyboś A., Andrzej Trzebicki (1607-1679) od 1658 biskup krakowski, „Rocznil Krakowski” 1987, nr 53, s. 5-16.

Przyboś A., Rożek M., Biskup krakowski Andrzej Trzebicki. Z dziejów kultury politycznej i artystycznej w XVII stuleciu Warszawa-Kraków 1989.

Raczyński E., Gabinet medalów polskich oraz tych które się dziejów Polski tycza poczawszy od najdawniejszych aż do konca panowania Jana HI Le Médailler de ca panowania janall. Le Medalle de Polog eou collection de médailles ayant rapport al histoire de cepays depuis les plus anciennes jusq'a celles, qui ont été frappés sous le régne du roi Jean III. (1513-1696), t. 1-2, Wrocław 1838.

Raczyński E., Gabinet medalów polskich oraz tych które się dziejów Polski tycza począsszy od najdawniejszych aż do końca panowania Jana III. Le Médailler de Pologne ou collection de médailles ayant rapport a l'histoire de ce pays depuis les plus anciennes jusq'a celles, qui ont été frappés sous le régne du roi Jean III. (1513-1696), t. 1-2, Berlin 1845.

Rokita G., Medal upamiętniajaccy królewska koronację Jana III Sobieskiego i Mar II Kazimiery w Krakowie pochodzacy z 1676 roku. Uwagi ikonograficzne, „Studia Europaea Gnesnensia” 2018, nr 17, s. 307-336.

Rożek M.,Katedra wawelska w XVII wieku, Kraków 1980.

Rożek M., Mecenat mieszczaństwa krakowskiego w XVII wieku, Kraków 1977.

Schaefer F.J., Dei gratia; Dei et Apostolicæ Sedis gratia, w: The Catholic Encyclopedia, t. 4 New York 1908, s. 679.

Schimmelpfennig A., Kundmann, Johann Christian w: Allgemeine Deutsche Biographie, t. 17, Leipzig 1883, s. 377

Skrabski J., Monstrancja, w:Rzemiosło Artystyczne Małopolski, 2020, https:// monstrancja-141.

Skrabski J., Portret Andrzeja Trzebickiego,

w: Sakralne Dziedzictwo Małopolski,

https://sdm.upjp2.edu.pl/dziela/por-

tret-andrzeja-trzebickiego

Sotkiewicz A., Biskup w:Encyklopedja kościelna podług teologicznej encykloped $j$ Wetzera $\mathrm{i}$ Weltego, t. 2, Warszawa 1873, s. 359-372.

Stachowiak J., Działalność papieska medalami pisana, w: Polskie medalierstwo kościelne - tradycja i współczesność Konferencja naukowa 17 grudnia 2007 r., red. P. Dudziński, K. Łatak, Kraków 2008, s. 25-55.

Stanislav Pavlovský z Pavlovic (1579-1598). Biskup a mecenáš umírajícího věku, red. O. Jakubec, Olomouc 2009.

Stankiewicz A., Treści propagandowe herbu złożonego Jana Stanisława Sapiehy z 1617/1620 roku, w:Źródła staropolskie i nauki pomocnicze historii, red. J. Rogulski, Kraków 2013, s. 295-340.

Štěpán J. Nejstaršímedailérské ražby olomouckého biskupství, w: Stanislav

Pavlovský z Pavlovic (1579-1598). Biskup a mecenáš umírajícího věku, red. O. Jakubec, Olomouc 2009, s. 133-135.

Štěpán J., Zlatník Donát Šolc, medailér olomouckého biskupa Stanislava Pavlovského z Pavlovic

"Numismatické listy" 2001, nr 56, S. 115-118.

Stężyński Bandtkie K.W. Numismatyka krajowa, t. 2, Warszawa 1839

Strzałkowski J., Słownik medalierów polskich i z Polska zwiazanych (1508-1965), Warszawa 1982.

Suchodolski S., Moneta możnowładcza i kościelna w Polsce wczesnośredniowiecznej, Wrocław 1987.

Tomkowicz S., Galerya portretów biskupów krakowskich w krużgankach klasztor OO. Franciszkanów w Krakowie, Kraków 1905.
Tomkowicz S., Zabytki budownictwa m. Krakowa. I. Szpital Ś. Ducha, Kraków 1892

Tschernyschow K., Die deutschen Münzen aus der Sammlung Jacob von Reichel, Beiträge zur Brandenburgisch/ Preussischen Numismatik",

Numismatisches Heft 2011, nr 19, s. 55-58.

Tylicki .., O gdanskiej historii sztuki i num zmatyce raz jeszcze, „Porta Aurea”, t. 9, 2010, S. 171-181.

Tylicki J., O historii sztuki i numizmatyce, czyli kto projektował niektóre donatywy gdańskie Zygmunta III, „Biuletyn Numizmatyczny" 2009, nr 1, s. 27-38.

Videman J.,Kardinál František z Dietrichstein a jeho mincovnictví, w: Kardinál František z Dietrichsteina (1570-1636). Prelát a politik neklidného věku, red. L. Mlčák, Olomouc 2008, s. 124-126.

Visser A., Joannes Sambucus and the learned image: the use of the emblem in lateRenaissance humanism, Leiden 2005

Wardzyń warsztatowa w kamieniołomach dębnickich od drugiej ćwierci XVII do poczatku XVIII wieku a "długie trwanie" form późnomanierystycznych i wczesnobarokowych, w: Studia nad sztuką renesansu i baroku, t. 11: Tradycja i innowacja w sztuce nowożytnej, red. I. Rolska, K. Gombin, Lublin 2012, s. 331-381.

Wardzyński M., Marmur i alabaster w rzeźbie i małej architekturze

Rzeczypospolitej. Studium historyczno-materiałoznawcze przemian tradycji artystycznych od XVI do poczatku XVII wieku, Warszawa 2015.

Warszawskie Centrum Numizmatyczne. Aukcja Nr 23, 24 lutego 2001 r., Warszawa 2001

Weisser B., 150 Jahre Münzkabinett. Menschen - Münzen - Medaillen, „Numismatisches Nachrichtenblatt" 2019, nr 68, s. 45-54.
Wieden, Bei der B., Mensch und Schwan, Bielefeld 2014.

Więcek A.,Dzieje sztuki medalierskiej w Polsce, Kraków 1989.

Wiśniewski J., Katalog prałatów i kanoników sandomierskich od 1186-1926 r. tudzież sesje kapituły sandomierskiej od 1581 do $1866 r$ r., Radom 1926.

Wołyniec B.M., Ostoja - uwagi nad dziejami herbu w średniowieczu i czasach nowożytnych w:Źródła staropolskie i nauki pomocnicze historii, red. J. Rogulski, Kraków 2013, s. 245-294.

Wystawa Sobieskiego w Krakowie (ciag dalszy), „Gazeta Toruńska”, r. 17, 1883, nr 230, s. 3

Zabytki XVII wieku. Wystawa jubileuszowa ana III w Krakowie 1883, Kraków 188 Zagórski I., Monety dawnej Polski jako tez prowincyj i miast do niej niegdy należacych, z trzech ostatnich wieków, wyd. E. Rastawiecki, Warszawa 1845.

Załęski S., O.O. Jezuici przy Kościele św. Piotra i Pawła w Krakowie. Szkic historyczny, Nowy Sącz 1896.

Zapletalová J.,(Art) Agents: Giovanni Petignie and the Network of Agents of the Olomouc Bishop Karl von LichtensteinCastelcorno, „Umění”, t. 65, 2017, s. $347-362$.

Zeltt J., Nowy skorowidz monet polskich, Warszawa 1877 (wyd. popr. i poszerzone Warszawa 1882).

Прозоровский Д.И., Коллекиия хранящихся в императорской Академии художесть гравюр на меди и резьбы на дереве сизображением медалей,

исторических событий и гербов. Гравюры, Санкт Петерсбург 1872

Якоб Рейхе ученый (1780-1856) Каталог выставкию Государственный Эрмитаж, red. Т. Таллерчик, Санкт Петерсбург 2003 